University of Rhode Island

DigitalCommons@URI

Open Access Master's Theses

1997

\title{
WAVES OF CHANGE: WOMEN, WORK, WAR, AND WEDLOCK IN COLONIAL NEWPORT, RHODE ISLAND, 1750-1775
}

Jonathan M. Beagle

University of Rhode Island

Follow this and additional works at: https://digitalcommons.uri.edu/theses

\section{Recommended Citation}

Beagle, Jonathan M., "WAVES OF CHANGE: WOMEN, WORK, WAR, AND WEDLOCK IN COLONIAL NEWPORT, RHODE ISLAND, 1750-1775" (1997). Open Access Master's Theses. Paper 1807. https://digitalcommons.uri.edu/theses/1807

This Thesis is brought to you for free and open access by DigitalCommons@URI. It has been accepted for inclusion in Open Access Master's Theses by an authorized administrator of DigitalCommons@URI. For more information, please contact digitalcommons-group@uri.edu. 
WAVES OF CHANGE: WOMEN, WORK, WAR, AND WEDLOCK IN COLONIAL NEWPORT, RHODE ISLAND,

1750-1775

BY

JONATHAN M. BEAGLE

A THESIS SUBMITTED IN PARTIAL FULFILLMENT OF THE REQUIREMENTS FOR THE DEGREE OF

MASTER OF ARTS

IN

HISTORY

3816

UNIVERSITY OF RHODE ISLAND

1997 


\section{Abstract}

The intent of this thesis is to explore connections between gender relations and the construction of a local discourse by which residents of late colonial Newport, Rhode Island, interpreted the coming American Revolution. Historians in recent years have documented a relationship between gender and the rhetoric of the Revolution and separately have linked the development of commercial economies to a desire for independence in the colonies. However, relatively unexplored are the possible connections between the nature of gender relations within the emergent economies and the appeal for independence.

The emergence of an urban economy in Newport dominated by commerce and consumerism wrought tremendous change in the way men and women interacted with each other in the city. Particularly affected was the traditional paragon of colonial gender relations - matrimony. This development proved disconcerting to many residents, who found remedy in the ideas of the Revolution.

Primary source materials, consisting of court records and newspaper publications, illustrate the intersections of gender and economics that gave the Revolution meaning for Newporters. Coupled with the work of other historians, this study proposes that the process was not unique to Newport, but rather characteristic of colonial port cities in that era of great change. As such, the scope of this thesis goes beyond mere local history. Indeed, it has as much to suggest about colonial America in general as it does about colonial Newport in particular. 


\section{Acknowledgments}

No work of historical inquiry is ever a solitary effort and this project could not have come to fruition without the profound support and guidance of a great many people. To begin with, credit for the inception of this project must go to three individuals who each do great credit to the discipline of history - Joel Cohen, Sharon Hartman Strom, and J. Stephen Grimes.

Dr. Cohen was instrumental in turning my once raw and timid mind into a more confident and mature intellect. His high expectations of his graduate students continually motivated me to master a subject I had previously approached with indifference, colonial American history. Moreover, his firstrate teaching skills provided me with the tools I needed to grasp not only history, but historiography as well.

It was in preparation for one of Dr. Cohen's term papers that I had the great fortune to meet J. Stephen Grimes, the archivist at the Rhode Island Supreme Court Judicial Records Center in Pawtucket, Rhode Island. Uncertain as to what topic to pursue for the project, Steve suggested I take a look at colonial divorce records. The result was a successful paper, ideas for further study, a greater understanding of the critical role of the archivist in historical research, and an appreciation for Steve as both a person and a professional. Without his keen familiarity of the sources and his commitment to me, this project would have been impossible. To his great credit, he always made me feel welcome by treating me like a scholar rather than a schoolboy.

While Joel Cohen and Steve Grimes helped alter the way I related to the discipline of history, Dr. Sharon Hartman Strom literally transformed my worldview. It was she who showed me the instrumental role of gender in the human experience and who encouraged me to pursue the present piece while 
it was still a tentative idea in my head. Her continual enthusiasm about the project and her confidence in my abilities kept the composition moving forward, while her astute criticism kept it on track. I will always be grateful for the opportunity to have worked with Dr. Strom.

Thanks must also go to Dr. Marie Jenkins Schwartz, who suggested that I expand my discussion concerning the impact of slavery on Newport women and forced me to think a little harder on this subject than I might otherwise have done.

The writing of this work involved numerous sacrifices by friends and family alike, so I would like to extend my appreciation to them for their patience. Somehow Jeff Byrd withstood my frequent inability to fraternize just enough to still regard me as a good friend. At times during the preparation of this thesis, both my mother and my father must have almost forgotten what their elder son looked like, yet nevertheless professed the pride and love in me that has always provided a secure foundation for my life. And my brother Christopher must be credited with helping me maintain that little bit of madness that ensures sanity. Finally, my fianceé Deborah Binder has been a pillar of strength throughout this entire endeavour. As she has willingly shared with me all the hopes and frustrations that accompany the graduate school experience, this thesis stands as much a tribute to her work as it does to mine. 


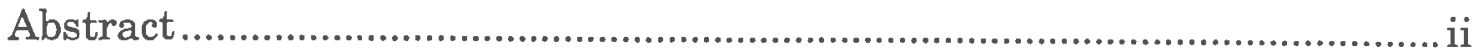

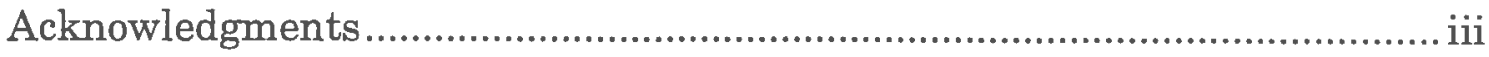

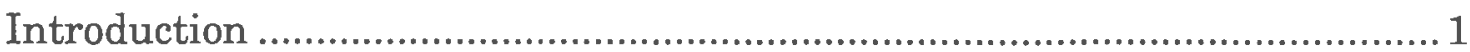

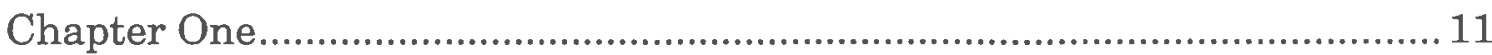

Riding the Waves

The Development of a Colonial Port City

Chapter Two. 48

Staying Afloat

Women's Economic Activities in a Commercial Seaport

Chapter Three. 94

Navigating the Court System The Gendered Dimension of Colonial Newport Litigation

Chapter Four

The Tides of War

Fortifying the City with Wedded Bliss

Conclusion

Bibliography 


\section{Introduction}

In November of 1755 , a recently widowed Phebe Battey filed suit against the Newport, Rhode Island, merchant Joseph Wanton, Jr., a man from a family of great political and economic distinction in the bustling seaport. The Wantons were the archetypal Newport family. Their initial fortune reputedly stemming from the boldness of family patriarchs William and John, who in 1694 outwitted and plundered a large pirate ship, the Wantons rose to prominence in the city on the strength of commercial shipping exploits. Economic success reaped political rewards and numerous Wanton men would come to hold significant positions within the colony's government before the American Revolution. When Phebe Battey sued John during those chilly days in November of 1755 , then, she was exhibiting a cetain mettle in challenging such a prominent community member.

Phebe's husband William had been in the service of Wanton as master of the sloop Charming Abigail when he died off the coast of Surinam in 1753. Typical of Newport merchants, Wanton had engaged Battey in the West Indian molasses trade, a prosperous trade that was instrumental to the economic fortunes of many Newporters. The captaining of such voyages could be lucrative, as it was a position of great trust. Once a vessel left Newport, the captain was charged with finding a propitious port in which to conduct business and secure the greatest return on investments. The success of the venture would determine the captain's commission. When Battey died, William Gardner Wanton assumed command of the Abigail, and finding among Battey's possession three large bills of exchange dealt them for eight hogshead of molasses, which he then added to the store reserved for the owner of the sloop, Joseph Wanton, Jr. Upon returning to Newport in 
December of 1753, William asked that Joseph deliver the eight hogsheads along with Battey's commission to his widow as recompense for the voyage. Though Joseph "did upon himself assure and faithfully Promise to deliver the said Phebe Battey of said Molasses when he should afterward be thereto Requested," he instead plotted "Craftily and Subtilly to deceive and defraud the said Molasses or any part thereof to the plaintiff."I Phebe was not fooled, however.

Hiring David Richard as her attorney, Phebe sued Wanton on the grounds that, as William Battey's widow and administratrix of his estate, she and Joseph were "Tennants in Common" of the molasses landed in Newport by the Abigail and therefore she was legally entitled to a cut of the profit. Variously pleading that "he hath fully accounted with" Phebe and that "he never promised and upon himself assumed in Manner and form" to reimburse her as she and her lawyer were suggesting, Wanton was able to stretch the case out over several years. ${ }^{2}$ In the meantime Phebe called in other debts owed her deceased husband, such as that owed by the baker George Gibbs. Finally, five years after William's death Phebe was awarded four hundred and thirty gallons of molasses determined by a team of auditors in 1758 to be "due from the said Wanton to the widow of the said Batty..."3

Phebe Battey's case speaks volumes about the character of life for the women of Newport during the late colonial era. This was a period of great transition for relations between men and women, a time in which conceptual understandings of gender were under great stress. In recent years, scholars have begun to assert that a person's perception of reality is shaped by a

\footnotetext{
${ }^{1}$ Phebe Battey v. Joseph Wanton, Jr., November 1755, Rhode Island Inferior Court of Common Pleas case file.

2 Ibid.

${ }^{3}$ Ibid.
} 
complex and dynamic social filtering process. Social constructs, impressions that are given meaning and transmitted throughout society via culture, mediate the formation of individual perception and experience. For instance, meanings attributed to biological difference in sex form one such construct, gender, which in turn informs the individual's organization of reality. As one of the foremost proponents of this school of thought, Joan Wallach Scott argues that "[e]stablished as an objective set of references, concepts of gender structure perception and the concrete and symbolic organization of all social life." 4 In late colonial New England, however, the verity of commonly-held assumptions and expectations about the sexes was called into question when manifestations that in the past had conferred them legitimacy were altered. As coastal agricultural regions such as Newport developed into urban commercial centers, there occurred a reorganization of socio-economic relationships within these communities that obfuscated important aspects of the dominant gender constructs.

The agricultural origins of Newport, Rhode Island, had fed a certain image of family as a unit of production and of the woman as the "helpmeet" of man. The tasks of men and women in an agricultural economy were distinct, yet complimentary. Raw materials produced by the male's husbandry were frequently converted into needed finished products, such as meals and clothes, by the wife's labor. As Jeanne Boydston puts it, "men and women were engaged in comparable and interdependent systems of production: both brought raw materials into the household, both spent long hours processing raw material into usable goods, and both conducted the exchanges necessary to supplement the family's own resources."5 This pattern of production has

\footnotetext{
${ }^{4}$ Scott, Joan Wallach, Gender and the Politics of History, (New York, N.Y.: Columbia University Press, 1988), 45.

5 Boydston, Jeanne, Home and Work: Housework, Wages, and the Ideology of Labor in the
} 
led Ruth Schwartz Cowan to conclude, and Laurel Thatcher Ulrich to concur, that "men and women had to work in tandem in order to undertake any single life-sustaining chore." 6 However, within this familial system of productive husbandry, the husband maintained the pre-eminent position of authority and decision-making.

Mary Beth Norton and other historians have argued that, to the early colonists, "heads of households were crucial links in the chain of hierarchical authority that governed their society."7 The formation of households in colonial New England was dependent upon the commencement of marriage. Marriage accorded family and the home legitimacy. As it was structured by the region's founders, who believed that "[i]n each relationship God had ordained that one party be superior, the other inferior," the institution of marriage was a distinct hierarchy in which the wife was to assume a position of subordination. ${ }^{8}$ Though their economic contributions to the preservation of the family might be equally dependent upon one another, a husband derived superiority over his wife by right of marriage. The woman who accepted this hierarchy, who obeyed her husband and her God, who subsumed her individual interests for the communal good of the family, and who remained so industrious was affectionately termed the "goodwife." Though the label possessed positive connotations for colonials, it set strict boundaries and assumptions against which a woman's activities were judged.

The extent to which a woman's virtue was contingent upon marriage is evident in the linkage of the terms "good" and "wife." Lee Virginia

Early Republic, (New York, N.Y.: Oxford University Press, 1990), 20.

6 as quoted in Ulrich, Laurel Thatcher, A Midwife's Tale: The Life of Martha Ballard, Based on Her Diary, 1785-1812, (New York, N.Y.: Vintage Books, 1990), 80.

7 Norton, Mary Beth, Founding Mothers and Fathers: Gendered Power and the Forming of American Society, (New York, N.Y.: Alfred A. Knopf, 1996), 39.

${ }^{8}$ Morgan, Edmund S., The Puritan Family, (New York, N.Y.: Harper and Row, 1966), 19. 
Chambers-Schiller has written that "Seventeenth-century New England deemed singlehood a sinful state, an evil to be exorcised from community life because such women menaced the social order."9 Even into the eighteenth century, she notes, the unwed woman was viewed as "disgraceful." The colonial woman gained identity only in relation to others, for whom she was to sacrifice any personal desires. As such, her industry was determined by the extent to which her labor served others. "[T]he lives of early American housewives were distinguished less by the tasks they performed than by forms of social organization which linked economic responsibilities to family responsibilities and which tied each woman's household to the larger world of her village or town."10 Given expression by seventeenth century agricultural and familial organization, this notion of proper womanhood persisted into eighteenth century Newport despite the fact that socio-economic transformations had placed it at odds with the predicaments faced by a growing number of the city's women.

In the eighteenth century, Newport and many other coastal communities turned away from agricultural production toward commercial trade. This transition had a tremendous effect on residents. As Boydston notes, "In general both men and women in town were likely to engage in more trade and less agriculture and household manufacture than their rural counterparts."11 This trade was not restricted to one's own community, however. The sea linked coastal towns and cities, providing for the expansion of trade outside individual communities into what historians have termed the "Atlantic economy." Increased volumes of trade to increased numbers of

\footnotetext{
9 Chambers-Schiller, Lee Virginia, Liberty, A Better Husband, (New Haven, Conn.: Yale University Press, 1984), 11.

10 Ulrich, Laurel Thatcher, Good Wives: Image and Reality in the Lives of Women in Northern New England, 1650-1750, (New York, N.Y.: Alfred A. Knopf, 1982), .

11 Boydston, Home and Work, 14.
} 
persons over an increased geographic region often made the barter system of exchange impractical and so heightened the role of cash in the eighteenth century economy. Such an economy allowed for the application of individual skill for personal benefit and independence. No longer were masculine and feminine labor roles locked in the interdependency of an agricultural economy. By commercializing her domestic skills, a woman could obtain the resources necessary for an independent existence. At the same time, the evolution of Newport into an older, more urbane community and its growing reliance on shipping worked to variegate the structure of households in the city.

Lee Virginia Chambers-Schiller and other historians have noted of colonial America that "[t]he outmigration of men from more established to less settled areas of the region or the West shrunk the pool of prospective husbands for women in Massachusetts, Connecticut, and Rhode Island."12 Jeanne Boydston has observed that "[t]he wives of sea-going men assumed virtually all of their husbands' customary daily responsibilities." 13 Increasingly women in Newport were faced with having to provide for themselves despite the social prescription that they labor for others. This was the situation Phebe Battey found herself in as she initiated suit against Joseph Wanton, Jr. Significantly, Chambers-Schiller found that the "transformation of American society from a production-based domestic economy to a consumer-based household economy" actually led women away from men. Far from migrating to younger communities and rural regions where men predominated, women instead "were drawn to the merchandising and manufacturing centers where jobs were most available."14 Though she

12 Chambers-Schiller, Liberty, A Better Husband, 29.

13 Boydston, Home and Work, 14.

14 Chambers-Schiller, Liberty, A Better Husband, 45. 
dates this process from 1790 forward, we shall see that it had in actuality begun some years earlier. In every way, these women defied the traditional markers of womanhood. They were not "goodwives;" often they were not even married. Rather than exclusively putting the interests of others first, they exhibited self-interestedness as they labored for their own benefit in the emerging cash-based economy of the Revolutionary era.

Historians such as Elaine Forman Crane have emphasized the economic origins of Newport's involvement in the Revolution. "I am as convinced today as I was seven years ago," she wrote in 1992, "that economic grievances precipitated Newport's entry into the war..."15 Joel Cohen has instead stressed the role of political and governmental forces in bringing revolution to Rhode Island: "[W]hen Rhode Island revolted it did so to preserve its liberal 'charter privileges,' its local economy and politics, and its traditionally independent nature." 16 Both interpretations articulate the importance of alterations in established interaction as the basis for Newport's involvement in the Revolution - Crane stressing the disruption of Britain's policies on established economic dealings and Cohen emphasizing the displacement of traditional political relations. Change is the common theme here and rightly so. But the changing character of relations among the city's inhabitants was pervasive and interconnected, and its sources multiple.

Joan Wallach Scott contends that historians must "eschew the compartmentalizing tendency of so much social history that relegates sex and gender to the institution of the family, associates class with the workplace and the community, and locates war and constitutional issues exclusively in

15 Crane, Elaine Forman, A Dependent People: Newport, Rhode Island in the Revolutionary Era, (New York, N.Y.: Fordham University Press, 1992), xi.

16 Cohen, Joel A., "Molasses to Muskets: Rhode Island 1763-1775," Rhode Island History, Vol. 34:4 (November 1975): 99-103. 
the domain of the 'high politics' of governments and states."17 This paper is an attempt to do just that. It asserts that gender, economics, and politics in eighteenth century Newport were interconnected, touching all aspects of life so that alterations in one area were understood to have consequences far beyond itself. If Newporters understood their community and its relation to the Revolution through gender, then the connections between the changes wracking the city in the late colonial era and the interaction between the sexes must be thoroughly mined in order to comprehend the nature of the American Revolution to Newport, Rhode Island.

Chapter one of this study examines in detail the evolution of colonial Newport society from its agricultural roots in the seventeenth century to its emergence as a leading city and center of commercial activity for the American colonies by the eve of the Revolution. Within this process originated a perceptual disjuncture between woman as an objective category of gender and women as subjects. The changing socio-economic circumstances experienced by women in the transition from rural agriculture to urban commerce challenged the impressions and assumptions from which Newporters derived meaning for the colonial notion of womanhood. As a result, the extent of her relation to either the forces of transition or tradition became an important mark for those determining a woman's character.

Chapter two details the relation of women to the forces of socio-economic change in Newport and suggests that some women employed these changes to fashion for themselves a construction of womanhood that embraced feminine autonomy. The chapter illustrates women engaging in this process through economic activites. Very often these were activities and livelihoods that emerged in conjunction with the socio-economic transformations of the city

17 Scott, Gender and the Politics of History, 6. 
and, while being informed by gender expectations, reorganized the terms of gender relations for these women. The impact of this occurrence can be gleaned from the court cases that form the basis of the third chapter.

The degree to which by the late colonial era socio-economic change had complicated understandings of gender in Newport and occasioned a disjuncture around the conception of colonial womanhood is evidenced by patterns within the Newport court records of the era. Chapter three examines those patterns. It posits that female litigants like Phebe Battey exhibited a boldness in the courtroom and elsewhere that was unexpected by men like Joseph Wanton, Jr. and is emblematic of a conceptual separation that had emerged between some men and some women regarding the feminine constitution. Significantly, at the very time that Newporters were confronted with divergences in the feminine constitution, they were also faced with disagreement over the nature of the English constitution. The two issues derived meaning from one another as Newport's residents particularly its men - struggled to determine the position of the seaport in regard to the coming Revolution. Politics, economics, and gender were conceptually linked to inform a paradoxical discourse that advocated the conservation of tradition in gender relations while promoting revolution against Mother England.

The final chapter of the thesis explores the connections Newport men made between local political, economic, and gender issues and the means by which these connections communicated significance to an understanding of the impending Revolution. So interconnected were these matters that public discussion of one was very frequently framed in terms of the others. As such, the local discourse on gender was rife with political and economic connotations just as politics and economics were given gendered meaning. 
This finding supports the theories of scholars such as Joan Wallach Scott who argue that "Gender is one of the recurrent references by which political power has been conceived, legitimated, and criticized."18 The paper concludes by suggesting that the processes observed for Newport on the eve of the American Revolution were indeed not unique. Rather, correlative phenomena in other colonial American seaports indicate that what occurred in Newport was part of a general trend that both shaped the colonial perception of revolution and informed the structure of gender relations in the newly-formed United States.

${ }^{18}$ Scott, Gender and the Politics of History, 48. 


\section{Chapter One}

Riding the Waves: The Development of a Colonial Port City

Most historians consider the mid-eighteenth century to be the "golden age" of Newport, Rhode Island. Indeed, as the fifth largest city in the American colonies, Newport was a vibrant, cosmopolitan, and generally prosperous seaport community that its ever-increasing number of visitors found quite appealing. It would, however, be misleading to present the socioeconomically complex nature of eighteenth century Newport as an everpresent given, for it was not a given; it was a development. Actually, the dynamic commercialism of Newport in the mid-1700s was the outgrowth of a conscious pattern of thought, a mindset, that had developed in Newport over one hundred years earlier and still dominated the thinking of the city's inhabitants prior to the American Revolution.

In addition to religious toleration and freedom of worship, economic prosperity, not mere subsistence, was a core ambition of Newporters from the beginning. It was this desire for economic affluence and the possibility of realizing it which fueled the city's drive toward the inter colonial commerce that would characterize the seaport by the mid-1700s and alter relationships among its inhabitants. The commercial development of Newport, Rhode Island, in the eighteenth century variegated the economic character of women and complicated colonial gender constructs that relied on the sovereignty of man in marriage for expression. The evolution of the seaport fostered household compositions that diffused authority within many families and engendered contrasting statndards of femininity and matrimony. Thus, the features of life for the city's women in the mid-eighteenth century, and for 
all its residents in general, cannot be adequately probed and elucidated without first examining the development of the community itself.

Rhode Island is perhaps most famous in American history as one of the earliest havens for religious dissidents within the now-United States. Some historians, such as Sydney James, have gone so far as to credit the colony with demonstrating the viability of religious liberty so well that without Rhode Island the First Amendment right to freedom of religious worship might never have come about. Religion can even be argued to be the cause for the foundation of the colony itself. Roger Williams and his followers, and Anne Hutchinson and her followers, did establish the first villages of the colony for religious reasons, namely they were either banished or otherwise forced out of Massachusetts Bay Colony due to their religious persuasions. Newport's lead founder William Coddington escaped almost certain banishment from Massachusetts for his beliefs by migrating to Rhode Island. Yet to focus so heavily on the religious constitutions of Newport's early inhabitants is to disregard other important aspects of their characters. These men and women were not one-dimensional; they did have concerns and interests in addition to religious worship. Hand in hand with religious concerns, their economic interests and attainments shaped the nature of their flight from Massachusetts, influenced the decision to relocate on Aquidneck Island, and had a tremendous impact on shaping the character of their new home. It is imperative to understand that, as Carl Bridenbaugh has argued, the migration to Aquidneck "was much more than a flight from religious persecution." "It was," he contends, "an agricultural-commercial experiment that had been thoughtfully and minutely planned in advance at Boston and

\footnotetext{
1 Bridenbaugh, Carl, Fat Mutton and Liberty of Conscience: Society in Rhode Island, 16361690, (Providence, R.I.: Brown University Press, 1974), 21.
} 
adequately financed by men who were thoroughly familiar with the management of estates."2 Bridenbaugh's comments and other evidence suggests that the choice of Newport as a settlement was dictated as much by economic concerns as by religious ones. In fact, the two were not wholly unrelated.

In his recent investigation of seventeenth-century Puritan culture, Stephen Innes has stressed the intimate connections between religion and economics in the Puritan mind. According to Innes, the New England Puritans' "providentialism - the belief that they were participating in the working out of God's purposes - made all labor and enterprise 'godly business,' to be pursued aggressively and judged by the most exacting standards."3 Thus, to early New Englanders, religious concerns were economic concerns and vice versa. The drive for profit was infused with religious significance, and in a culture in which religious activity was of paramount importance economic gain became a priority. When the founders of Newport arrived on the shores of Aquidneck, then, they did so believing they had a stake in economic gain and possessing an intent to prosper, characteristics that would long define their progeny.

It is significant that Newport's founders did not originally cast their eyes on Aquidneck Island as the destination of their exodus from Massachusetts. Rather they first considered the Piscataqua region but rejected it as unsuitable to their needs. They were searching for, in the words of Carl Bridenbaugh, "the finest and most fertile land available, land having open fields or meadows with sufficient grass for pasturing cattle or that might be

\footnotetext{
2 Ibid., 22.

${ }^{3}$ Innes, Stephen, Creating the Commonwealth, (New York, N.Y.: W.W. Norton and Company , 1995), 7.
} 
mowed for hay." 4 Concerning the choice of Newport as a settlement, Elaine Forman Crane has concluded that "[i]t is unlikely that this particular location was a happy accident, since the settlers were aware of the harbor's excellent reputation and growing use in the coastal trade." Indeed, it was this combination of land and sea which would facilitate early prosperity for the nascent city. And since several of the town's founding families, like the Coddingtons, Coggeshalls, Brentons, and Sanfords, already possessed mercantile wealth, knowledge, and connections prior to the establishment of Newport, it seems likely that they found the waters of Narragansett Bay appealing for reasons other than religious. As one contemporary described them, these were "banished men, yet rich." 6 Historians have agreed. Elaine Crane concurs that "they were fairly wealthy men, able to buy and develop large tracts of land which in time would produce surpluses to pay for essential manufactured goods from abroad."7 To them she attributes colonial Newport's "never-ending search for commercial markets."8

The background of Newport's founders and the path taken to achieve the remarkably rapid success of the city's establishment suggests that from the beginning Newport, Rhode Island, was about the search for financial success. What has been written about the character of Newport's early settlers, that "[t]hey knew what they wanted, and they knew how to get it," would become equally applicable to their children's children and later generations. ${ }^{9}$ For instance, the taste for elegance among eighteenth century Newporters (manifested in a preference for the large, splendid domiciles that

\footnotetext{
${ }^{4}$ Ibid., 15.

${ }^{5}$ Crane, Elaine Forman, A Dependent People: Newport, Rhode Island in the Revolutionary Era, (New York, N.Y.: Fordham University Press, 1985), 1.

6 as quoted in Bridenbaugh, Fat Mutton, 15.

7 Crane, A Dependent People, 2.

8 Ibid., 2.

${ }^{9}$ Bridenbaugh, Fat Mutton and Liberty of Conscience, 14.
} 
characterized the city) reflected a taste that had characterized Newporters from the beginning. In the seventeenth century, "[t]he relative security of life on the island led many of the more wealthy citizens to lay out large estates on which they built fine mansions..."10 Such grand residences were reflections of the premium placed on affluence and economic achievement by Newporters. Of Newporters in the mid-eighteenth century, Shiela Skemp notes, "[t]he average artisan or shopkeeper was not a leveller, nor did he wish to drastically alter the social and economic order in which he existed. $\mathrm{He}$ merely desired a chance to improve himself, to rise above the station to which he was born, and to gain a measure of power, prosperity, and security."11 By the late $1600 \mathrm{~s}$, such interest in economic enrichment had permeated both class rank and religion.

Carl Bridenbaugh has argued that the coming of the Quakers to Rhode Island in the mid-seventeenth century and their quick acceptance by established inhabitants proved to be an important turning point for the development of Newport. "In a surprisingly short time, they [Quakers] expanded and rationalized the commerce of Rhode Island and its environs with notable success," he contends. ${ }^{12}$ The cohesive nature of this sect, its famed entrepreneurial abilities, and wide connections reinforced and further developed the city's appetite for, and ability to realize, economic prosperity. Interestingly, many of the town's earliest inhabitants, including the Coddingtons, Clarkes, and Coggeshalls, were converted to Quakerism, so that by the close of the seventeenth century nearly one-half of Newporters were

\footnotetext{
${ }^{10}$ Bridenbaugh, Carl, Cities in the Wilderness: The First Century of Urban Life in America, 1625-1742, (New York, N.Y.: Alfred A. Knopf, 1960), 9.

11 Skemp, Sheila, A Social and Cultural History of Newport, Rhode Island: 1720-1765,

(Ph.D. dissertation: The University of Iowa, 1974), 397.

12 Bridenbaugh, Fat Mutton, 107.
} 
Quakers. ${ }^{13}$ Significantly, however, by the mid-eighteenth century when membership in the Anglican Church in Newport had developed distinct connotations of wealth, an appreciable number of these Quakers (again including the Clarkes, Coddingtons, and Coggeshalls) discarded Quakerism in favor of Anglicanism. ${ }^{14}$ The Quakers greatly promoted the area's commercial development, further enabling wealth to accumulate in the seaport. By the mid-1700s, almost no religious group in Newport could claim not to include men of some wealth among its ranks. Even such small sects as the Jews and Huguenots could point to the financial prosperity of Aaron Lopez and Stephen Ayrault respectively. The search for economic gain among Newporters knew no religious bounds. As each sect was willing to transact business with one another in order to pursue personal prosperity, all benefited economically from their religious toleration.

The economic prosperity of Newporters in the seventeenth century was clearly grounded in agricultural enterprise. The fertile soil of Aquidneck made farming an attractive endeavor, and by 1645 it was being written that "this place abounds with corne."15 Apple orchards soon began to dot the island. "Every farmer who planned to make his land a home and not just a way station planted an orchard not far from the house."16 The fruit found its way not only into local foods, but, as it was often pressed into cider, into drink as well. The great money-making enterprise of Newport in the $1600 \mathrm{~s}$, however, was live stocking. Carl Bridenbaugh has noted the advantages of livestock over grain as commercially-profitable commodities, including the fact that "[i]n shipping weights... a pound of meat or a pound of wool was

\footnotetext{
13 see Bridenbaugh, Fat Mutton and Liberty of Conscience, page 65 for this statistic.

14 see Crane, A Dependent People, 59.

15 as quoted in Bridenbaugh, Fat Mutton, 29.

16 Hawke, David Freeman, Everyday Life in Early America, (New York, N.Y.: Harper and Row, Publishers, 1989), 38.
} 
worth more by far than a pound of wheat," and has chronicled the significant role of livestock in creating prosperity in early Newport. ${ }^{17}$ Tellingly, Newporters were willing to expend much energy and resources in order to make live stocking commercially viable.

The native grasses of Aquidneck were not nutritionally substantial enough to support the livestock that had been brought with the founders to Newport in the $1630 \mathrm{~s}$. But rather than drop live stocking to pursue other ways of life, certain Newporters were determined to make it a viable pursuit regardless of cost. "We can reasonably assume that the great landowners who had the money, William Coddington in particular, procured the [necessary grass] seed from overseas and distributed it not only on Aquidneck but to the small farmers about Providence."18 Clearly perceiving potential profit in an endeavor such as live stocking, Newporters would not be easily deterred from its pursuit. "They had expertise in mercantile, political, and agricultural affairs on both sides of the Atlantic, and they knew the necessary ingredients for a successful venture."19 Indeed, with the new feeding methods live stocking did prove profitable and Newporters promptly sought and found markets outside Rhode Island for their sheep, cattle, horses, and pigs as well as for their grains. If, as David Freeman Hawke and others suggest, "[t]he self-sufficient farm rarely, if ever, existed in early America...[and] [f]rom the beginning trade permeated the everyday life of every farmer," then in seventeenth century Newport this phenomenon was as much a result of choice, of aspiration, as of necessity. ${ }^{20}$ Mere economic subsistence was never a goal of Newporters; the intent was always prosperity. Thus, it is not

17 Bridenbaugh, Fat Mutton, 39.

18 Ibid., 32.

19 Crane, A Dependent People, 2.

${ }^{20}$ Hawke, Everyday Life in Early America, 153. 
surprising that Newporters "passed through the subsistence-farming phase so quickly that it might be said they beat the frontier." 21 Innes has noted the similarly rapid commercial development of Rhode Island's northern neighbor, Massachusetts. By the 1640s, merchants and mariners from throughout Europe had established business contacts with Puritan Massachusetts and the young colony was operating its first ironworks. And "[b]y the early eighteenth century, Massachusetts was second only to London as a center of shipbuilding in the English-speaking world."22 Though commercial shipping grew throughout the period in Newport, the predominantly agricultural basis of its economy gave the town a distinctly rustic atmosphere throughout the seventeenth century.

Seventeenth century Newport displayed few of the trappings of urbanity that would characterize the city in the eighteenth century. In fact, it is a stretch to even label the Newport of the 1600 s a city. Not crowded by any means, its population of around 2,500 late in the century was comfortably spread out along the waterfront. Sanitation and fire prevention, often concerns of crowded colonial populations, were of little real worry to Newporters. As crime was of insignificant proportions to warrant strong policing of the town, police patrol was generally lax and the town jail was frequently neglected. Wandering swine were a common sight about the streets, valued by residents not only for their nutritional content but also for their utility as street-cleaning scavengers. Not until the mid-1700s, after Newport had begun to move toward a much more urban environment, did the animals become enough of a nuisance to justify a law forbidding them on the streets of the city. Despite growing commerce throughout the seventeenth

21 Bridenbaugh, Fat Mutton, 27.

22 Innes, Creating the Commonwealth, 272. 
century, the city's first centralized marketplace, the Brick Market House, was not constructed until the following century. Even social life was of a generally rural character. There was no newspaper; instead information was frequently disseminated via the local taverns. Taverns "provided a gathering place for townfolk to obtain dinner or a round of drinks with friends or to join in more or less serious discussions."23 For men, other diversions included hunting, which to early Newporters was "more than a sport because of the danger and nuisance of such animals as bear, wildcats and wolves."24 It is also likely that men engaged to some degree in horse racing and cockfighting, two of the more popular forms of entertainment in the rustic atmosphere of seventeenth century America.

Historians of colonial America have noted a distinct communitarian strain in seventeenth century New England that by the early nineteenth century had all but disappeared from public life. Far removed from the Lockean notions of individualism and voluntary contractualism, early New Englanders subscribed to the idea of an inherent communalism in human relationships. According to this notion, the community preceded the individual in time and so constituted a creation of God rather than of humans. The contrast to Lockean contractualism could not have been more stark. "Although Puritans believed that a free consent was essential to a covenant, they also believed that freedom consisted in the opportunity to obey the will of God.... Since God had ordained that men live together in family, church, and state, they must do so."25 Rather than making the community responsible for the protection of the individual, individuals were charged with

23 Good, L. Douglas, "Colonials at Play: Leisure in Newport 1723," Rhode Island History, Vol. 33, No. 1 (February 1974), 9.

24 Ibid., 16.

25 Morgan, Edmund, The Puritan Family, (New York, N.Y.: Harper and Row, 1966), 26. 
maintaining the sanctity of the community. The prominence of God in this worldview gave religious leaders pre-eminent authority in the local and colony-wide governments. Richard Bushman has observed of early New England settlements that "[t]he town covenants, even in recalcitrant Rhode Island, symbolized the ideal of community life which the first settlers wished to recover in founding governments in 'love, union and order,' for the blessing of all and to the glory of God."26 Indeed, the communitarian principle informed every sort of interaction among the early colonists.

Stephen Innes has recently documented the role of Puritan communalism on economic transactions in seventeenth century New England. According to Innes, Puritan dictates informed a system of economic exchange designed to inhibit rampant self-interest: "The doctrine of stewardship mandated that profit seeking be firmly grounded within a communitarian setting. Acquisitiveness needed to be tempered and disciplined... by a respect for communal obligation. ${ }^{27}$ Those who placed their own economic interests above the parameters set by the community could be severely punished, and various measures were adopted to ensure compliance to the community, including the concepts of the "just price" and price controls as well as the practice of "charivaris." "Economic exchanges," writes Innes, "took place within the realm of commutative justice." 28 This is not to suggest that personal profit was eschewed by early New Englanders, but rather that "[s]urplus wealth was to be used to help the poor, and commercial success was to be measured by the good it conferred on the community as much as by the wealth it brought to the individual himself." 29 In a society that, as Gordon Wood has

\footnotetext{
26 Bushman, Richard L., From Puritan to Yankee: Character and the Social Order in Connecticut, 1690-1765, (Cambridge, Mass.: Harvard University Press, 1967), 4.

27 Innes, Creating the Commonwealth, 59.

28 Ibid., 165.

29 Ibid., 189.
} 
asserted, "intuitively conceived of individuals as enmeshed in social relationships - bound tightly to the community in a variety of personal ways," men, women, and children labored as much for others as for themselves. ${ }^{30}$ As Laurel Thatcher Ulrich reminds us of colonial American economic relationships, "Dependence upon family labor inevitably meant dependence on neighbors." 31

Women in agricultural environments, Joan Jensen asserts, "worked with men and children in a farm family household, essentially unchanged in its basic form of property ownership and work relations."32 A typical early New England woman's surroundings in an economy based on husbandry has been well-described by Laurel Thatcher Ulrich in Good Wives:

If we were to draw a line around the housewife's domain, it would extend from the kitchen and its appendages, the cellars, pantries, brewhouses, milkhouses, washhouses, and butteries which appear in various combinations in household inventories, to the exterior of the house, where, even in the city, a melange of animal and vegetable life flourished among the straw, husks, clutter, and muck. Encircling the pigpen, such a line would surround the garden, the milkyard, the well, the henhouse, and perhaps the orchard itself... The line demarking the housewife's realm would not cross the fences which defined outlying fields of Indian corn or barley, nor would it stretch to fishing stages, mills, or wharves... ${ }^{33}$

Within these surroundings, women worked alongside men in a variety of tasks. Indeed, women in an agricultural-based economy were of tremendous significance to men: "The tasks performed by farm women made them absolutely essential to the success of any agricultural venture [for] [w]ithout

\footnotetext{
${ }^{30}$ Wood, Gordon S., The Radicalism of the American Revolution, (New York, N.Y.: Vintage Books, 1991), 72.

31 Ulrich, Laurel Thatcher, "Housewife and Gadder: Themes of Self-Sufficiency and Community in Eighteenth Century New England," "To Toil the Livelong Day": America's Women at Work, 1780-1980, eds. Carol Groneman and Mary Beth Norton (Ithaca, N.Y.: Cornell University Press, 1987), 28.

32 Jensen, Joan M., Loosening the Bonds: Mid-Atlantic Farm Women, 1750-1850, (New Haven, Conn.: Yale University Press, 1986), xiv.

33 Ulrich, Good Wives, 13.
} 
a family a man was likely to have a difficult time..."34 Women, too, had trouble trying to subsist in such an economy without their husbands. As Koelher notes of Rhode Island widows in the seventeenth century, "Although widows usually administered their deceased husbands' estates, they often remarried shortly after receiving the power of executorship."35 Even in the eighteenth century, agricultural endeavors were just not conducive to the establishment of single-person households. Perhaps it was this understanding that helped lead the widow Mary Carr of Newport to lease her farm to Thomas Crowley and his family for the rent of 700 pounds per year. To further illustrate the point, it may be useful to do some numbercrunching.

Of Rhode Island in the seventeenth century Lyle Koelher has written, "women asserted themselves in religious and political realms, but not in the economic world." $36 \mathrm{He}$ does not adequately explain this incongruity, but in the case of Newport it likely has much to do with the nature of the area in that century. The women lived in an environment that would indeed promote female involvement particularly in religious affairs (as both the many Quakers and the legacy of Anne Hutchinson encouraged strong female activity in the church) yet stifle the type of economic activity that would remain visible in the historical record over two hundred years later. In regard to the women of Northern New England in the 1600s, Laurel Thatcher Ulrich concludes: "Informal, oral, local, petty - female enterprise appears as the merest flicker on the surface of male documents." ${ }^{37}$ The Newport

\footnotetext{
34 Jensen, Loosening the Bonds, 53.

35 Koelher, A Search for Power, 328.

36 Koehler, Lyle, A Search for Power: The "Weaker Sex" in Seventeenth-Century New England, (Urbana, Ill.: University of Illinois Press, 1980), 328.

37 Ulrich, Laurel Thatcher, Good Wives: Images and Reality in the Lives of Women in Northern New England, 1650-1750, (New York, N.Y.: Oxford University Press, 1982), 46.
} 
economy was not at this time particularly conducive to the sort of female economic participation overtly evident in eighteenth century Newport records. Their work was not the type of labor by which women could typically support themselves. There were apparently no women in the seventeenth century like the forty-two Newport women in 1774 who resided alone, hence Koelher's finding that the women on Aquidneck in the 1600s "did not live alone, nor were many self-supporting." 38 The largely rustic nature of seventeenth century Newport, where much of the population lived off the land, did not encourage the development of the solitary house-dweller nor the then less-than-ideal single parent head of household that by the next century characterized the highly commercialized Newport.

The most comprehensive and detailed census taken while Rhode Island was still a colony occurred in 1774 , by which time Newport had evolved into a major urban colonial seaport and the fifth-largest city in the American colonies. However, the neighboring towns on Aquidneck, Middletown and Portsmouth retained the rural qualities that had characterized Newport in the previous century but had since been lost. A comparison of household structure between Newport and these two largely rustic towns reveals that the more populated and urbane Newport, with an economy that (as shall be explained in more detail later) had become almost wholly dependent on inter colonial commerce, began to promote household structures that were virtually nonexistent in its more rural neighbors. As noted earlier, forty-two Newport women lived alone in their dwellings at the time of the census. Several men also lived alone. In neither Middletown nor Portsmouth, however, did anyone, male or female, live alone. Significantly, the urban, commercial conditions of Newport seem to have made more viable a

38 Koehler, A Search for Power, 328. 
household headed by a single adult of one sex. For example, in Newport twenty-four households contained adult men but no white female resident over the age of sixteen, yet no Portsmouth home was without at least one white female inhabitant over sixteen. In Middletown, only two dwellings were without an adult white female, but both possessed a source of labor that probably performed many "wifely" functions... slaves; Henry John Overing owned three slaves, while George Rome controlled the labor of four. More statistically significant are the numbers of households without an adult male resident. Only two households in Portsmouth and six in Middletown in 1774 failed to contain at least one man over the age of sixteen. In Newport that number reached approximately 195 .

What are to be made of such statistics? When we keep in mind that the Newport of the 1600 s more closely resembled the nature of the Middletown or Portsmouth in the following century than it did of itself in the eighteenth century, it seems likely that the incongruencies between the household structures presented above are consistent with those that would be found between the less urbanized, less commercialized Newport of the seventeenth century and the more urbane Newport of the eighteenth. Indeed, Portsmouth's 1774 population of about 1,232 whites and its lower commercial volume make it not unlike Newport in the 1600 s, which at the turn of the eighteenth century numbered 1,886 inhabitants. And Middletown's approximately 781 residents, whose disenchantment with "[i]ncreased urbanization of the thickly inhabited portions of Newport community [had] led five hundred freeholders of 'the wood's part' to seek" to establish their own more rural town in the early 1740 s, compares well with the 492 residents Newport contained in 1660. Gary Nash has written that "[t]he growth and commercial development of the northern seaport towns brought 
about the restructuring of social groups..." 39 Indeed, fueled as it was by the continuing desire for prosperity, Newport's continued movement toward an urban, highly commercialized environment, and the changes that movement entailed for the city's inhabitants, do seem to have provided opportunities for residents, both men and women, to fashion household structures that were rarely viable in Newport's more rural environment of the seventeenth century.

Under pressure from the forces of geography, demography, and economy, the communitarian nature of seventeeth century life gave way in the 1700 s to the individualism and unrestrained capitalism that would characterize later centuries. Richard Bushman has succinctly described this transformation in thought and action of New Englanders in the eighteenth century as moving from Puritan to Yankee. Puritan communalism was increasingly challenged by socio-economic change which promoted commercial expansion and individual interest at the expense of communal good. In Connecticut, "[a]fter 1690 , more and more farmers entered trade, and a common interest in commerce had the opposite effect from a mutual involvement in agriculture.... [as] [p] eople loved wealth more than religion, and that spirit had destroyed the peace of society." 40 Similarly, Helena Wall has concluded that in the mideighteenth century, "[t]he shattering of religious consensus, the increasing complexity of economic relationships and the influence of the market, population growth, migration: all pushed private life and individual decisions beyond the reach of the community."41 A growing commercialism favored

\footnotetext{
${ }^{39}$ Nash, Gary, The Urban Crucible: The Northern Seaports and the Origins of the American Revolution, (Cambridge, Mass.: Harvard University Press, 1986), 246.

40 Bushman,

41 Wall, Fierce Communion, 128.
} 
individual autonomy and self-reliance over communal dependence. Such was the case with Newport in the mid-eighteenth century.

When Ann Franklin, widow of Newport Mercury founder James Franklin, died in 1763 her benevolence was commended as increasingly extraordinary for the seaport. "She was a faithful Friend," her obituary proclaimed, "and a compassionate Benefactor to the Poor, (beyond many of the great Estates) and often relieved them in the Extremity of Winter." 42 An even stronger indictment of the frayed sense of communal obligation among many of the city's residents was authored by "a Friend to America," who in 1769 proposed the alleviation of poverty and suffering in Newport through a self-help plan that would raise the town's poor "above Dependence upon their Neighbors" since "[as] you know most People are very unwilling to either lend or give."43 That fewer individuals were willing to care for the less fortunate, even if they were relatives, was acknowledged by the Rhode Island General Assembly when it required in 1755 "That the Children of all Parents incapable of supporting themselves, shall, at their own Charge, (if of sufficient Ability) relieve and maintain such Parents in the same Manner as Parents are... directed to support their poor Children, under the same Penalties, and to be applied in the same Manner."44 Sheila Skemp has concluded that as Newport matured into a city and ranks of the indigent rose, "resentment of them was also vocalized more frequently." 45

It was in the early eighteenth century that Newport, Rhode Island, really began to mature as a city. As it blossomed into a center of commerce, it lost reliance on local agricultural production as a vital source of revenue. Instead,

\footnotetext{
42 Newport Mercury, April 25, 1763.

43 Newport Mercury, June 5, 1769.

${ }^{44}$ Acts and Laws of The English Colony of Rhode Island and Providence Plantations, in New England, in America, printed by Samuel Hall (Newport, R.I., 1767).

45 Skemp, $A$ Social and Cultural History of Newport, Rhode Island, 335.
} 
it served as a harbor city that supplied goods from certain ports to meet the needs of other ports, rather like a middleman. An influx of merchants who understood Newport to be a budding seaport with a drive to prosper whetted Newporters' desires by transforming the city's commercial economy "from a sporadic, limited trade with a handful of ports to a complex trade involving hundreds of voyages annually to ports throughout the West Indies and continental colonies." ${ }^{46}$ Increasingly, in its pursuit of profit, the decisions of the growing merchant class tied Newport ever closer to the burgeoning Atlantic economy of the eighteenth century. This development had tremendous consequences for structuring the sources of economic opportunity in the city. The increasing number of commercial vessels sailing in and out of the city, for example, created a considerable demand for crafts and industries geared toward the sea. Worn ship rope needed replacement; torn sails necessitated mending or replacement; damaged barrels or boxes required repair; even whole vessels occasionally needed to be exchanged for new ones. Not surprisingly, as the demand for seafaring services increased so too did the supply. Newport in the 1700s saw a tremendous growth in the number of coopers, ropewalkers, sailmakers, caulkers, and other craftsmen who plied their trades in the port. The fact that Newport became well-known for its residents' abilities to produce quality vessels at reasonable rates in the eighteenth century indicates the prominence of shipping to Aquidneck. The more shipping Newport merchants engaged in and the more demand they created for jobs to facilitate that shipping, the more Newporters oriented the city's occupational structure toward the sea and loosened Newport from the agricultural moorings of its past. In fact, Newport fits well the process of

\footnotetext{
46 Withey, Lynne, Urban Growth in Colonial Rhode Island, (Albany, N.Y.: State University of New York Press, 1984), 19.
} 
development Gloria Main has described for New England coastal towns in general during the $1700 \mathrm{~s}$. In Newport, as in other Northern seaports, "[i]ncreasing population densities created exchange opportunities that encouraged both men and women to specialize and invest more time in nonfarm occupations." 47

An attendant phenomenon to the increasing amount of commercial goods entering and exiting Newport harbor was a distinct rise in the number of Newporters engaged in shopkeeping. Just after the turn of the eighteenth century, Carl Bridenbaugh believes, Newport had fewer shops than other towns of comparable size, including Charleston, South Carolina. ${ }^{48}$ Sheila Skemp notes, however, that "[r]etail shops, in fact, were becoming increasingly prominent in the 1720 s and $1730 \mathrm{~s}$, an indication that business was booming and effective demand was increasing." 49 According to Elaine Forman Crane, by the revolutionary era "in Newport everyone (or nearly everyone) had something to sell."50 The shops sold an increasingly wide diversity of goods as trade routes expanded and altered to include much of the Atlantic coast, the West Indies, and even on occasion direct trade with Great Britain. In the Newport Mercury of September 7, 1762, for instance, Jonathan Otis announced the arrival of South Carolina rice for his shop's shelves, while Henry Murphy advertised "Choice St. Kitts RUM" and a shop on the Long Wharf retailed "The London MAGAZINE for the Year 1761, compleat, and neatly bound." The city's women related to these shops in a variety of ways.

\footnotetext{
47 Main Gloria L., "Gender, Work, and Wages in Colonial America," The William and Mary Quarterly, 3rd Series, Vol. LI, No.1 (January 1994), 62.

48 Bridenbaugh, Cities in the Wilderness, 190.

49 Skemp, A Social and Cultural History of Newport, Rhode Island, 126.

${ }^{50}$ Crane, A Dependent People, 49.
} 
Most women purchased necessary goods and occasional luxuries for themselves or their families in the local shops. C. Dallett Hemphill asserts that when Salem, Massachusetts, "men and women entered the store, mill, or tavern, they were quite likely to encounter the merchant's, miller's, or tavernkeeper's wife and female servants." 51 Indeed, the wives, daughters, and other female relatives of Newport's male shopkeepers could on occasion be found tending the store with or for the men, as the gentlewoman Mary Ward was possibly doing in 1752 when Edmund Andrews "at said Times come into the Shop of Richard Ward, Esq. [Mary's husband] in Newport and threatened and abused the said Mary and then did strike or hit the said Mary one blow upon her Body with the Handle of a Brush..."52 This incident suggests that perhaps women in such positions were not awarded any type of gentlemanly deference. Least deterred by the possible difficulties concomitant with shopkeeping must have been those Newport women like Temperance Grant who tended their own shops. Clearly, in some way, shape, or form the increasing number of shops affected the daily lives of nearly all Newport women as by 1761 , Sheila Skemp estimates, there existed perhaps ninety shops in the city. Retail had truly become a prominent component of the Newport economy by the late eighteenth century.

As Newport's economy shifted, more and more of the city's men in the eighteenth century made their living off the sea as mariners, a trend of great consequence for the city's women. Perhaps some men felt that they had few alternatives. As the city's population grew there began to be greater competition for available jobs, the demand for which seemingly outstripped

\footnotetext{
51 Hemphill, C. Dallett, "Women in Court: Sex-Role Differentiation in Salem, Massachusetts, 1636-1683," The William and Mary Quarterly, 3rd Series, Vol. XXXIX (January 1982), 167.

52 Rex v. Edmund Andrews, Rhode Island Court of General Sessions, May 1752.
} 
the supply. The Town Council noted the increasing "Number of able-bodied Men, Women, and Children, who are poor Persons, that have no Employ..:" in 1764.53 Every historian who has studied Newport in the 1700s has also noted the increasing number of poor and indigent in the city as the century wore on. Crane contends that "[a]lthough the percentage of poor remained unchanged throughout the 1760 s and early 1770 s, the actual number of poor increased during these years." ${ }^{4}$ Even earlier, Bridenbaugh notes, Newport had growing numbers of poor. However, as Gary Nash has documented, Newport was not alone in this problem, suggesting the phenomenon may have been endemic to urban maturation in colonial America. "It was hard to ignore," he has written of Boston, New York, and Philadelphia in the mid$1700 \mathrm{~s}$, "the fact that in all the cities the largest buildings erected after $1765 . .$. were constructed to contain the impoverished, a growing criminal element spawned by poverty, and a noncriminal middle-class group whose only offense against society was an inability to weather the economic storms of the period." 55 Clearly some Newport men were pushed into the life of a mariner by circumstances and, as Lisa Norling has written of New England sailors, "thousands went to sea to seek their fortunes (or at least some hard-earned cash) on trading ventures... of up to eighteen months' duration."56 Of these "Jack Tars" Jesse Lemisch has written that "there were many... in the colonial period... who left the land in flight and fear, outcasts, men with little hope of success ashore."57

\footnotetext{
${ }^{53}$ Newport Mercury, January 2, 1764.

54 Crane, A Dependent People, 64.

55 Nash, The Urban Crucible, 218.

56 Norling, Lisa, 'How Frought with Sorrow and Heartpangs': Mariners' Wives and the Ideology of Domesticity in New England, 1790-1880," The New England Quarterly 65 (September 1992), 425.

57 Lemisch, Jesse, "Jack Tar in the Streets: Merchant Seamen in the Politics of Revolutionary America," The William and Mary Quarterly, 3rd Series, Vol. XXV (July 1968), 377.
} 
So prevalent was seafaring as an occupation for Newport males that "there was scarcely a Newport family that did not claim at least one mariner in its ranks." 58 Rather than subsisting through the stationary lifestyle of a yeoman farmer, these men were engaging themselves in an occupation that demanded mobility. Every day mothers and fathers were bidding Godspeed to their seafaring sons departing for far off lands; left at the docks were wives and children wondering if they would ever see their husbands and fathers again. Yet every day, too, husbands, fathers, and sons were returning from long absences overseas to renew relationships that had been placed on hold. There is perhaps no greater illustration of just how thoroughly the culture of the sea embedded itself in Newporters' lives than the decision of Hannah Lacy and her husband to name their boy Neptune. The nature of the seaport was truly reflected in the character of its inhabitants. The stay of the Jewish merchant Aaron Lopez in Newport provides a prime example of this reflection.

Though family connections drew Lopez to Newport in 1752, these connections must be understood within the context of the city's development. Newport, indeed the colony of Rhode Island in general, was by the mid-1700s already distinguished by its history of religious toleration, making the city attractive to those of the Jewish faith. Though their numbers were always small and evidence indicates some degree of discrimination against them in eighteenth century Newport, Jews felt comfortable enough in the city to have constructed in the $1760 \mathrm{~s}$ an attractive synagogue and to have hired a prominent Christian architect, Peter Harrison, to design it. Moreover, "Jewish merchants were prospering as well as the others, slowly finding their

58 Skemp, A Social and Cultural History of Newport, Rhode Island, 356. 
way into the affairs of the colony."59 Lopez's decision to emigrate from Lisbon to Newport was likely influenced by the rather favorable religious and economic climate his relatives enjoyed in the American city. Not surprisingly given the local economy, Lopez took to commerce soon after his arrival on Aquidneck in 1752. "During the 1750s," Virginia Bever Platt has written, "he expanded rather tentatively into overseas commerce, combining a little tea smuggling with the legal importing of goods from England."60 Apparently dissatisfied with the earnings from such activity, Lopez was soon willing to invest capital in the slave trade, a trade that had grown significantly in the city during the 1700s and one in which his cousin Jacob Rodriguez Rivera was already then engaged.

The pursuit of profit led Newport merchants into active involvement by the turn of the eighteenth century in the infamous triangular trade. Rum, often distilled in Newport itself, was shipped by certain of the city's merchants to Africa. There it was exchanged for the African slaves that would furnish the merchants with the West Indian molasses necessary for Rhode Island rum production. Though occasional outcries were heard concerning the city's involvement in the slave trade, they must have made little impression. There was money to be made by the trade in human cargo and the seaport's involvement in the trade steadily grew. Newport slavers were always able to find local distillers willing to sell the rum necessary to procure slaves and, as Platt has observed, "[a] slaving captain was not hard to find in Newport..."61 Accordingly, "Newport... had the dubious distinction

\footnotetext{
59 James, Sydney V., Colonial Rhode Island - A History, (New York, N.Y.: Charles Scribner's Sons, 1975), 208.

60 Platt, Virginia Bever, "'And Don't Forget the Guinea Voyage': The Slave Trade of Aaron Lopez of Newport," The William and Mary Quarterly, 3rd Series, Vol. XXXII, (October 1975), 602.

61 Platt, "And Don't Forget the Guinea Voyage'," 603.
} 
of being more heavily engaged in the slave-carrying trade than other colonial ports." 62 So strong was economic gain a motive for Newporters that even religious persuasion was not a sufficient deterrent. "It is one of the ironies of Newport," writes Elaine Forman Crane, "that it was both dominated by slave traders and populated by Quakers."63 Indeed, there were Quakers who, despite the sect's growing distaste for slavery, were actively involved in the trade. Most others were complicit. "When the Friends finally prohibited slavery among themselves in the 1770 s, Abraham Redwood chose to retain his slaves rather than his membership in the Society."64 That the slave trade flourished in Newport was no coincidence. Rather, it was a reflection of the long-standing value placed on economic profit. To turn a profit Newporters were willing, as one inhabitant admitted in 1762, to contemplate "any scheme of trade."65 Aaron Lopez's numerous slaving voyages prior to the Revolution reflect just such an attitude.

Britain's wars for empire during the eighteenth century did not leave Newport untouched. The wars, particularly the Seven Years' War, severely disrupted the entire Atlantic commercial economy, cutting off various ports and making voyages increasingly costly in time and money. This situation had a tremendous impact on Newport, as the city's economy by this time had become what Jacob Price has described as an "artificial" economy "based upon no imperatives of geography but upon a series of historical accidents that brought together a trading population there and facilitated the accumulation of capital and entrepreneurial and technical skills."66 A

62 Crane, A Dependent People, 20.

63 Ibid., 80.

64 Ibid., 81.

65 as quoted in Crane, A Dependent People, 11.

66 Price, Jacob M., "Economic Function and the Growth of American Port Towns in the Eighteenth Century," Perspectives in American History, Vol. 8 (1974), 151. 
commercial economy such as Newport's was particularly sensitive to the dangers on the high seas created by war. Central regions of commercial activity for the city's merchants could become difficult to reach. Trade with the French West Indies was frequently prohibited and trade with the British West Indies was hazardous, as the enemy was often prowling the sea lanes. In fact, all ocean-going trade was precarious during such conflicts. Yet to withdraw from oceanic commerce would have damaged the Newport economy even more profoundly, so dependent was it on the sea. Instead, Newporters characteristically sought out ways to profit from their predicament.

Though some Newport men participated in organized military undertakings with the British against the Spanish and French, the chief contribution of Newporters to Britain's war efforts was in the form of privateering. The nature of privateering fit the character of the city. Having grown up near the wharves and ships, many Newport men probably had a proclivity for naval service over land service. Bill Baller's investigation of military mobilization during the Revolution in Marblehead, Massachusetts, a town with a seafaring culture akin to Newport, suggests as much. "Although they fought well on land, most Marblehead men preferred service at sea."67 Like Newport, "[p]rivateering perfectly suited Marblehead's temperament and its traditions."68 Newport's cultural emphasis on the sea, however, was from the beginning intimately related to its cultural emphasis on the pursuit of profit. And privateering promised profit, as portions of the plunder from enemy vessels were promised to captain and crew alike. Privateering for profit was nothing new to Newporters of the mid-1700s. "Legend has it, " writes Sydney James, "that the brothers William and John Wanton, both in

${ }^{67}$ Baller, Bill, "Kinship and Culture in the Mobilization of Colonial Massachusetts," The Historian, Vol. 57, (Winter 1995), 293.

68 Ibid., 294. 
their early twenties, began their spectacular rise to fame and high office by organizing a band of about thirty friends, who sailed out of Newport armed with nothing more dangerous than pistols and by a clever stratagem captured a large pirate ship in 1694."69 But most privateering ventures were not nearly so successful. Still, Carl Bridenbaugh estimates, during the French and Indian War "Rhode Island actually issued thirty-five commissions to Newport ships before 1760 , and about one-third of the ... adult males, including slaves, went a-cruising."70

The determination to reap profits despite the risk also propelled many merchants and sea captains to conduct clandestine trade with the enemy during times of war. Newport was consistently cited by authorities as a great haven for such activity. It was also known as a safe refuge for pirates, whose plunder many residents were not reluctant to have fill their coffers. To be sure, other cities had such reputations as well, but not every colonial city did. That Newport had them attests to other colonials' thinking about its inhabitants' values and priorities.

Though not surprised at the city's success, Newport's founders would probably have been amazed at the transformations their city had undergone by the mid-1700s. The commitment to oceanic commerce had wrought tremendous change. Symbols of commercial and cultural maturity had multiplied. According to Carl Bridenbaugh, wharves in the city, numbering approximately thirty in the $1740 \mathrm{~s}$, doubled between the $1740 \mathrm{~s}$ and $1760 \mathrm{~s}$, signaling an ever-growing commitment to the sea. A badly-needed lighthouse was constructed on neighboring Conanicut Island in 1749 to safely usher the additional traffic in and out of the port. The attractive Brick Market House

69 James, Colonial Rhode Island-A History, 116.

70 Bridenbaugh, Cities in Revolt, 63. 
began operations in the 1760s. Fruitless attempts at establishing a local newspaper in the 1720 s and 1730 s met with success in 1758 with the establishment of the Newport Mercury. Further divesting the city of its rural heritage, the Town Council decided that the stray animals roaming the streets were now more detrimental than beneficial to Newporters. Specifically referring to Newport as "compact," a 1748 law disallowed "any Hog or Swine to run at large, in any of the Streets, Highways, or Commons, within the compact Part of the Town of Newport ..."71 Similarly, in 1759 it was decided that "if any Horse shall at any Time be found going at large within the Limits of the Town of Newport, it shall be lawful for any Inhabitant of said Town to take up and impound such Horse."72

As the city shed its agricultural heritage, the road to wealth in eighteenth century Newport became inextricably linked to the sea. To illustrate, based on the city's 1772 tax assessment list the two most prevalent occupations of the top tax bracket were ones wholly dependent on the Atlantic economy for their prosperity, merchants and distillers. A third, innkeepers, were benefited by the increasing transience of much of the population and the growing reputation of the city as a pleasant retreat for vacationers. "At the height of Newport's prosperity," Elaine Forman Crane estimates, "as many as 400-600 vacationers might have spent the season, which ran from May through October."73 Yet the city attracted more than just those on the "upand-up"; it was also a magnet for the "down and out."

As noted earlier, eighteenth century Newport was characterized by an increasing number of indigent. "By the 1750s," Lynne Withey has observed,

\footnotetext{
71 Acts and Laws of The English Colony of Rhode Island and Providence Plantations, in New England, in America, printed by Samuel Hall, (Newport, R.I.: 1767).

72 Ibid.

73 Crane, A Dependent People, 60.
} 
"Newport had both an almshouse and a workhouse," a phenomenon that Gary Nash has noted for other eighteenth century colonial cities such as New York, Philadelphia, and Boston. ${ }^{74}$ Then, as now, people perceived cities as arenas of opportunity and as a thriving seaport Newport attracted its fair share of hard-luckers. In regard to crime in Newport, Bridenbaugh contends that "the hitherto Arcadian little city on Rhode Island came in for a series of rude shocks after crime signalized its coming of age with the execution of John Shearman for burglary in 1764."75 Evidence suggests that greater transience, female as well as male, and more frequent law-breaking characterized the urbane Newport of the eighteenth century. For example, in 1756 Christiana Renshen and Julian Woolford, two transient women who had recently entered Newport, found themselves before the court in November answering the charges of theft levied against them. Though they pleaded innocent, they were found guilty of stealing from the shopkeeper John Cook. Ben Franklin's account in his Autobiography of his run-in, during the mid-1720s, with a couple of women aboard a Newport ship bound for New York also attests to a growing mobility of the seaport's female population and illustrates a disjuncture between the thinking of men and women concerning the female character.

Having just finished a visit with his brother John, who had lived in Newport for quite some time, Franklin boarded a sloop to New York. During the voyage, Franklin became acquainted with a pair of young women who had also boarded the ship in Newport. It was an acquaintance Franklin's description hints was rather flirtatious in nature, "a daily growing familiarity between me and the two young women, which they appeared to encourage,"

\footnotetext{
74 Withey, Urban Growth in Colonial Rhode Island, 62.

75 Bridenbaugh, Carl, Cities in Revolt: Urban Life in America, 1743-1776, (New York, N.Y.:

Alfred A. Knopf, 1968), 300.
} 
as he relates it. ${ }^{76}$ Witnessing this whole scenario unfold was a "grave, sensible, matronlike Quaker woman with her attendants." Significantly, possessing a wariness of Newport women which Benjamin seemed to lack, she, not Franklin, sensed that his young acquaintances were no good. At one point in their journey she pulled him aside and explained:

Young man, I am concerned for thee, as thou has no friend with thee, and seems not to know much of the world, or of the snares youth is exposed to; depend upon it, those are very bad women; I can see it all in their actions; and if thee are not upon thy guard, they will draw thee into some danger. 77

Persuaded by the gentlewoman to keep his distance, Franklin declined an offer put forth by the young ladies upon reaching New York to "come and see them" where they lived in the city. The following day "the captain missed a silver spoon and some other things, that had been taken out of his cabin, and knowing that these were a couple of strumpets, he got a warrant to search their lodgings, found the stolen goods, and had the thieves punished."78 That the entire episode warranted enough significance for Franklin to recount in his Autobiography is telling. Whether because he was blinded by an affection for the two women or by colonial society's idealization of "proper" behavior for a woman, Franklin was clearly too trusting of the women. He was aghast that women could, and would, act as such. Whereas before the revelation of their crime Franklin identifies the two as "women," his reference to them as "strumpets" after the exposure of their misdeeds indicates a mental dissociation of their activities from his conception of womanhood. That the Newport Quaker woman was wary of the women suggests that she had had prior experience with "very bad women" and understood that the reality of

76 Franklin, Benjamin, Autobiography, (New York, N.Y.: Bantam Books reprint, 1982), 29.

77 Ibid., 29-30.

78 Ibid, 30. 
colonial women's behavior did not always match the ideal, an understanding many Newport men seemed either less willing or less able to grasp.

Sometime during the dark hours of September third or fourth, 1760, someone broke into a dockside warehouse belonging to the Newport merchant Benjamin Mason. The thief or thieves involved in the break-in seem to have been rather selective; presumably there were more items available to filch from the warehouse than only the "two Pieces of Cloth-coloured Shalloon... and one Piece of Poplins" that were taken. Determined to apprehend the perpetrators, Mason recounted the details of the incident in the Newport Mercury and offered a reward "If any Person will detect the Thief or Thieves, so that he or they may be brought to Justice..." Mason's choice of words is revealing for what it implies about his conception of femininity. Despite the fact that the pilfered fabrics were as valuable to women as to men (and probably more useful given the woman's role as needleworker for the colonial family), Mason nevertheless assumed the culprit(s) to be male. Like Franklin, Mason's conception of colonial femininity did not include connivance and thievery, base traits which were incongruent with the notion of women as the "softer sex." Indeed, he could not even entertain the thought that one of the city's many women could have assisted in the crime against him. "And if it is suspected more than one [thief] are concerned, if either will discover his Accomplice or Accomplices," Mason added to his announcement, "he shall have the above reward, and be neither prosecuted nor exposed." It is unlikely that Mason's use of the pronoun "he" was meant to include women. Documents that sought to address both men and women, for instance, often employed the gender-neutral term "person," a word Mason himself used to address the reader of his ad, whom he perceived as a possible informant. Thus did Mason believe that if a woman were to be involved in 
this ugly incident, surely it would be in this more becoming role. As the example of Mary Brown illustrates, however, this conception of femininity proved increasingly problematic.

Mary Brown arrived in Newport late in the year 1762 with a tale to tell. According to Mary, she, along with her mother and father, the Reverend Josiah Brown, was forcibly taken from her home in Deerfield, Massachusetts, by Native Americans in 1739. Her captors murdered her parents and carried Mary north into Canada, where she would remain for the next twenty-three years. Whether she was released or escaped in 1762 she did not say, but in June of that year she left Canada and headed south for the colonies. By December, 1762 she had found her way into Newport and announced her presence to the town via the Newport Mercury on December 13th. As numerous men and women daily entered and left the bustling city of around 6,800 inhabitants, Mary's arrival in Newport was likely paid little notice. To garner attention to her plight, she sought out the local paper. Like so many merchants who advertised their newly arrived wares, Mary turned to the Mercury to advertise her arrival in the hope that she might find family. Mary, the paper sympathetically announced, "thinks she may have some Relations still living, who are hereby inform'd that she is now in Newport, where they may hear of her by enquiring of the Publishers of this Paper."79 Newporters would hear of Mary Brown again the following week, but unfortunately not as favorably as one might hope.

On December 20, the Newport Mercury announced that Mary Brown, "having been detected in Stealing, was committed to Gaol..."80 Individual acts of petty theft were rarely commented on in the Mercury, so it seems 
Mary's act had particularly rankled the paper, which admitted it had previously allowed Brown to "advertise in our last to find her Relations." 81 The episode allowed a doubt in the printers' minds about Mary's sad story to advance to an irritated challenge to the woman's very identity. On December 13, the Mercury had been sympathetic yet skeptical of Mary's tale of woe, but not skeptical enough to reject its publication. "One Mary Brown, who, as she says, was taken by the Indians at Deerfield..." began their relation that day of her plight. The subsequent announcement of her incarceration the following week suggests a sense by the paper's editors that Mary, "as she calls herself," was as fraudulent as her story. Though still not on the scale of larger cities like Boston and New York, "[c]rime and the general disorder which accompanies it," Sheila Skemp contends for Newport, "was to be sure on the upswing in this period."82 The Town Council tried to clamp down on the growing problem of transience and poverty in the city, implying its irritation with the situation. The evidence, however, suggests that it was fighting a losing battle.

As Helena Wall has so ably demonstrated, an enforced sense of community pervaded colonial American society. In many regards, a person's private life was public property. "Throughout colonial America, settlers supported the preeminence of the community, relied on the family as a source of social order, and empowered local authorities to protect communal values and stability."83 Particularly in New England, there existed a long-held belief that a community in essence "owned" its residents and was hence responsible for their conduct. A narrowly defined term, residency was established only

81 Ibid.

82 Skemp, A Social and Cultural History of Newport, Rhode Island, 137.

83 Wall, Helena, Fierce Communion: Family and Community in Early America, (Cambridge, Mass.: Harvard University Press, 1990), 3. 
by birth or the formal permission of the community as represented by the local town council. Non-residents who either did not seek or were denied resident status were deemed suspect. The uneasiness such persons caused communities is evident both by the use of the anxiety-laden term "stranger" to define them and the construction of a widely-used system of dealing with such strangers, the "warning-out" system. The warning-out system was designed to preserve one's own community by driving out non-residents and forcing them to return to the towns or villages of their legal residency, which were seen as being responsible for these people (particularly if the stranger seemed likely to become a town charge). However, the notion of fixed residency implied by the long-standing system was increasingly at odds with the growing mobility and transience that characterized Newport by the mid1700s. Faced with this dilemma, the Newport Town Council significantly chose to fight change with tradition. Rather than discard the tradition of fixed residency, the Council employed it as a foil against the city's rising number of transients.

On October 6, 1760, the Council initiated a strategy designed to rid the city of those that did not belong. The Town Sergeant was ordered to "Go Over the Town from House to house and Enquire what familys they have and when he finds Any that are not Inhabitants to Warrant them to Appear at the Town Council the 10th day of November... to Give An Acco[un]t of themselves to said Council." The same day saw the Council grill Latham Clarke, a vagrant from Hopkinton, over his recent return to Newport, the town of his birth. Officials were determined to make visible those whom the populace, mobile city had allowed to become invisible. But the magnitude of the problem and the inadequacy of the proposed solution were ironically suggested in April of 1761 when one Rachel Jacobs was brought before the 
Council. Though admitting she was not a native of Newport but rather of Dartmouth, Massachusetts, Rachel revealed that she "has been here two years Last fall, but unknown to said Council." 84 She then asked to make application for residency. Whether her request was granted or not we do not know, but her brief appearance in the historical record provides a glimpse into the evolving character of Newport, an increasingly dynamic, diverse city whose inhabitants' lives were also increasingly mobile and diverse, a sense of which can be further gleaned from the city's newspaper.

The content of the Newport Mercury mirrored the character of the city it served; the significance of the sea and of commerce, the importance of slaves and the slave trade, the growing incidence of crime, and Newport's involvement in Britain's affairs could all be evidenced from a single issue of the paper. On September 23, 1760, for example, two Newport privateering vessels, the brigantine Diana and the schooner Success, were fitting out "in Order to cruise against His Majesty's Enemies" and encouraged those with an interest in "making their Fortune" to join their outfits. That same day found Benjamin Mason still searching in vain for the thief or thieves that had raided his warehouse earlier in the month. Yet Mason was not the only Newporter on the hunt that day. The innholder James Hardy announced his search for a female Native American slave of his who had "RUN away last Thursday Night." His predicament was shared by Abe Michener, whose "Indian wench" had fled her bondage in Newport and, Michener supposed, "gone to Dartmouth." While some slaves were fleeing bondage, others, such as the "YOUNG Negro Fellow" and the "LIKELY Negro Girl" advertised in the Mercury, were up for purchase, commodified like so much else in the bustling commercial seaport. Caleb Gilbert advertised his "Turks Island

84 Newport Town Council Record Book \# 13 (1760-1763), April 6, 1761. 
SALT;" Jacob Richardson publicized his wares "Just Imported from LONDON"; and Christopher Townsend sought to unload "a Schooner about 40 Tons, lying at William Reed Wharfe, at the Point, with Anchors, Cables, Boat, ect. for Cash or good Security." 85

Fueled by a cultural emphasis on financial gain, the economic diversification of colonial Newport yielded transformations in the very way the city's inhabitants related to and perceived one another. Merchants, not gentlemen farmers, dominated positions of authority and often dictated the direction of the economy. Growing crime and vagrancy led to increased policing of the town's residents. The presence of African and Native American slaves instilled both hope and fear among the city's white inhabitants, who understood them as sources of income yet agents of disorder as well. Racial tension in Newport was surely high in 1751 when it was discovered that Peter Taylor's slave Cambridge had been plotting a slave revolt by intending to kill local slave owners in the city. ${ }^{86}$ And the changes in the economy also fostered changes to relationships between the sexes.

The long-standing pursuit of profit that spawned the steady growth in ocean-going commerce and the rising, increasingly mobile population, which combined to help transform Newport in the eighteenth century, also helped create a society that promoted various activities and relationships outside of marriage which worked against the gender roles it may have encouraged within the institution. In a revealing article concerning women in seventeenth century Salem, Massachusetts, C. Dallett Hemphill suggests the significance that the process of urbanization may have had on defining gender roles and relations. Early in Salem's history, when it was yet a rather

85 see Newport Mercury, September 23, 1760.

${ }^{86}$ Rex v. Cambridge, General Sessions Record Book, May 1751, 38. 
rural region (similar to seventeenth century Newport), gender roles were relatively loosely defined. Women could be found transacting men's business, working alongside their husbands in the fields, tending livestock, and performing other tasks traditionally assumed to be of a masculine nature. Of Northern New England women between 1650 and 1750, Laurel Thatcher Ulrich has similarly concluded that "[a]lmost any task was suitable for a woman as long as it furthered the good of her family and it was acceptable to her husband." 87 And Joan Jensen has made like discoveries for rural Pennsylvania in the eighteenth century, finding accounts that "provide enough evidence, for example, to call for revision of some historians' conclusion that women did not work in the fields." 88 However, as Salem's economy began to orient itself toward the sea and develop urbanity, gender roles began to diverge and crystallize, contends Hemphill. "As husbands became gunsmiths, coopers, cutters, or schoolmasters, and thus less dependent on agriculture for subsistence, their wives' share in familial economic production fell off." 89 Their role as consumers, however, was accentuated by the growing commercialism of Salem and they became more domestic. Patricia Cleary also suggests that "women may have had more responsibility for shopping activities after midcentury." 90 But if urbanization diminished female economic production within the institution of marriage, it also promoted it outside marriage, thus accentuating the divergent characters of wed and unwed women. Significantly, too, urbanization helped

87 Ulrich, Good Wives, 37.

88 Jensen, Loosening the Bonds, 46.

89 Hemphill, "Women in Court," 172.

90 Cleary, Patricia "'She Will Be in the Shop': Women's Sphere of Trade in Eighteenth-

Century Philadelphia and New York," The Pennsylvania Magazine of History and

Biography, Vol. CXIX, No. 3 (July 1995), 188. 
create a diversity in women's economic fortunes that further accentuated differences in relation to matrimony.

Historians of Newport have observed that late in the colonial era wealth became more heavily concentrated in the hands of the city's elite, a phenomenon experienced by other colonial seaports as well. Elaine Forman Crane writes of these cities that "wealth was increasingly channeled into the hands of fewer people, while each community was faced with a growing number of inhabitants unable to provide for themselves." 91 The wives of the wealthy, Shiela Skemp notes, "led a life of relative frivolity."92 For these women, "any broadening of their social lives came in large measure from their role as ornaments and enhancements to the festivities of men."93 As such, contributors to the Newport Mercury could excoriate such women publicly and wonder "How far the Vanity of our Ladies in dressing, and of our Gentlemen in drinking, contributes to the general Misery of the People?"94 At the same time, however, others could lament the "Number of able-bodied Men, Women, and Children, who are poor Persons..."95 Indeed, Lynne Withey estimates that approximately forty-five percent of Newport's population in the 1770 s were too poor to be taxed. ${ }^{96}$ Life for these women was far from frivolous. Inside or outside of marriage, they could ill-afford to play the role of ornament. Even some middle-class women "relied on public charity or the help of friends, or, alternatively, secured a position as school mistress or clerk..."97 Thus were two types of marriages presented to Newport women, one characterized by a wife's inactivity in the public economic realm (except

\footnotetext{
91 Crane, A Dependent People, 9.

92 Skemp, A Social and Cultural History of Newport, Rhode Island, 22.

93 Ibid., 23.

${ }^{94}$ Newport Mercury, August, 13, 1764.

95 Newport Mercury, January, 2, 1764.

96 Withey, Urban Growth in Colonial Rhode Island, 56.

${ }^{97}$ Skemp, A Social and Cultural History of Newport, Rhode Island, 23.
} 
perhaps as a consumer) and the other by forced activity in the marketplace. The growing number of poor in Newport coupled with the increasingly transient nature of marriage in the seaport community ensured more of the latter type. At the same time, the commercialization of Newport provided more and more opportunities for more and more women to survive without husbands by supplying occupations which, as Cleary notes of shopkeeping, were "usually understood by contemporaries as falling within accepted norms for women's family employment, [yet] had the potential to transcend or contravene those mores." 98

The evolving character of the city's economy provided Newporters with divergent sets of feminine economic characters. The first hewed more closely to traditional ideas about the role of a wife as an economic dependent and resembled the seventeenth century Rhode Island women Lyle Koehler describes. The second, which follows Gloria Main's observation that more New England women were "working outside the home in the final decades of the colonial period," was characterized by sustained public economic endeavors. ${ }^{99}$ Though it was this second character which gained prominence as Newport headed into the Revolution, it was the first which was embraced by many as the standard, the epitome of femininity. In a culture sensitized to issues of economic import, these Newporters were keenly aware of the economic dimensions of gender and by the mid-eighteenth century perceived that changes in the city's economy were adversely affecting that paragon of colonial gender relations... matrimony.

98 Ibid., 182.

99 Main, "Gender, Work, and Wages in Colonial America," 65. 


\section{Chapter Two}

Staying Afloat: Women's Economic Activities in a Commercial Seaport

The complex yet often subtle relationship between women and the colonial American economy has received significant attention from scholars in recent years. By supplementing information obtained from official political and economic documents with sources hitherto neglected, historians have formulated a more inclusive definition of what constitutes economic value and constructed a new understanding of the role of women in the early American economy. The image of the colonial economy that has traditionally dominated the discipline's discourse is of a gender-defined, dual economy driven by men from whom colonial women were virtually prohibited contact. Women are presented in this discourse as having controlled a different, less public and hence less important ecomony, one in which their activities had little bearing on the overall health and course of the general economy. Recent historians, however, have questioned the validity of such a model.

According to Jeanne Boydston, the development of a cash-based market individualism in the late colonial era initiated a perceptual exclusion that continues to this day of non-wage, particularly female labor from economic valuation. Prior to this time, economic utility was judged by what she terms "labor contribution" rather than by any monetary reward. Under this definition of economic value, the work of the colonial woman that frequently went without monetary remuneration - cooking, cleaning, childcare, gardening, cloth production and repair - nonetheless contained economic value. It was part of the overall economy of household production and interdependency that characterized the seventeenth and early eighteenth century. "Family subsistence in early America was achieved by hundreds of 
transactions with neighbors." Though it went unpaid, feminine labor formed a key component of the early American economy and was generally acknowledged to be as crucial to individual and family survival as masculine work. The notion of a gender-dichotomized economy in which feminine labor was disconnected and devalued, Boydston contends, developed only after the emergence of a cash- and wage-based economy in the late eighteenth and early nineteenth centuries. "Economic life, while still based in the family unit, was coming to be seen as an activity shaped by individual interest, characterized by market contact and money-making (the "penny"), and focused on extra-household activity - none of which well fitted the work of housewifery."1

T.H. Breen has noted the way in which the consumerism of the American colonies after the mid-eighteenth century was conceptually associated with dependency, a term that other historians such as Edmund Morgan have found was becoming anathema to colonists of the Revolutionary era. In this new conceptual understanding of economy, which was in its infant stages during the Revolutionary era, conventional gender constructions dictated that man became the producer and woman the consumer. Yet contentions that colonial commercial development reduced the female role in economic production and cast her in the role of consumer ignore the many ways in which the economy constantly formed and reformed relationships between men and women that frustrated the assignation of conventional gender constructions to the dichotomous economic categories of producer and consumer. ${ }^{2}$

\footnotetext{
1 Boydston, Jeanne, Home and Work: Housework, Wages, and the Ideology of Labor in the Early Republic, (New York, N.Y.: Oxford University Press, 1990), 29.

2 see, for instance, Hemphill, C. Dallett, "Women in Court: Sex-Role Differentiation in Salem, Massachusetts, 1636-1683," The William and Mary Quarterly 3rd Series, Vol. XXXIX (January 1982):164-175 for a discussion on the means by which commercialization cast the
} 
While Boydston's efforts focus primarily on establishing the economic utility of women's unpaid work, other historians have noted the ways in which women could continue to play the role of producer in the emerging cash-based marketplace of the colonial era. Due to the prominent position of men in the monetary marketplace of early America, it is easy to dismiss the reciprocal influences of women on the marketplace and of the marketplace on women. In her intriging work Women Before the Bar, Cornelia Hughes Dayton contends that the developing cash-based commercialism of the eighteenth century actually did work to circumscribe many women's involvement in economic transactions. However, to admit as much is not to deny that women could play a meaningful role in this type of economy; in fact, Dayton found that some women, particularly widows, could and did prove to be "important source[s] of both consumer and commercial loans and therefore, it must be acknowledged, played a modest but significant part in the capitalization and commercial development of the countryside."3 Dayton's findings reinforce my contention that female economic pursuits were not wholly relegated to a more informal, barter-based sector of the colonial economy. It is, in fact, difficult to categorize the economic activities of the late colonial era woman, for she was an economically multifaceted creature. A variety of factors could muddle neat distinctions between genders in the Revolutionary economy.

Current research suggests that the economic character and utility of a particular woman was influenced by a variety of factors. The three most significant for the purposes of this study include place of residence, marital status, and spousal employment. In regard to place of residence, Jeanne 
Boydston notes that "in general, both men and women in town were likely to engage in more trade and less agriculture and household manufacture than their rural counterparts."4 As has already been suggested and will be illustrated in greater detail, this pattern holds true for Newport. Additionally, because colonial society made crucial legal and economic distinctions between married and single/widowed women, marital status had a tremendous impact on the economic livelihoods of women, and shifts in marriage patterns could well effect change in female economic mannerisms, as occurred in colonial Newport. Even among married women, however, the nature of wives' economic activities varied by the character of their husbands' vocations. Mary Blewett, for example, found that though the wives of the early Republic's shoemakers were prohibited from extensive involvement in the shoe industry, they often were responsible for "a small part of the work - the sewing of the upper part of the shoe."5 Jeanne Boydston affirms that "wives were often expected to integrate into their own schedules substantial aspects of their husbands' occupations." 6 Though underway, the conceptual separation of economic production of goods and income from the home and the woman was far from complete in the late eighteenth century.

With the shift in male occupational tendencies occasioned by the transformation of Newport's economy in the 1700s, more and more boys who in the seventeenth century would likely have become yeomen farmers were instead becoming mariners. No longer did the city's male youths hang

\footnotetext{
${ }^{4}$ Boydston, Home and Work, 14.

5 Blewett, Mary H., "The Sexual Division of Labor and the Artisan Tradition in Early Industrial Capiatlism: The Case of New England Shoemaking, 1780-1860," To Toil the Livelong Day, eds. Carol Groneman and Mary Beth Norton, (Ithaca, N.Y.: Cornell University Press, 1987),

6 Boydston, Home and Work, 15.
} 
around the barns and fields; rather, "[a]s soon as school was out they would run to the wharves, swarm up the rigging of the ships, and shinny to the topmast striving to be the first to place a cap on the tip." 7 The lure of the sea was strong in Newport and many boys grew up, whether by choice or circumstance, to make their livings on the water, an eventuality of tremendous consequence for the city's women. Since colonial women were expected to marry, as increasing numbers of men became mariners so too did more and more women become mariners' wives, a status that could frequently be both physically and emotionally difficult. Such marriages were often, as one such wife described them, "'frought with sorrow and heartpangs'."8

Marriage to a seaman was full of trials and tribulations. "Unlike female inhabitants of agrarian societies," Bill Baller has discovered of eighteenth century Marblehead, Massachusetts women, "the women of Marblehead were used to sons and husbands being away from home for long periods." Indeed, depending on the destination, a sea voyage could last months, sometimes years. Though the husband was still nominally the head of the household, this meant that while he was at sea the mariner's wife was effectively left in charge of the family hearth. This situation placed such women in rather odd circumstances with regard to their legal status. As married women, mariners' wives were in a legal state of coverture, a condition that "prohibited them from owning property, establishing businesses, signing contracts, or in

\footnotetext{
${ }^{7}$ Good, Douglas L., "Colonials at Play: Leisure in Newport 1723," Rhode Island History, Vol. 33, No. 1, pg. 16.

8 as quoted in Norling, Lisa, "How Frought with Sorrow and Heartpangs': Mariners' Wives and the Ideology of Domesticity in New England, 1790-1880," The New England Quarterly, Vol. 65 (September 1992), 446.

9 Baller, Bill, "Kinship and Culture in the Mobilization of Colonial Massachusetts," The Historian, Vol. 57, No. 1 (Winter 1995), 295.
} 
other ways managing personal affairs or supporting themselves."10 Such activities were deemed inappropriate and unnecessary for married women, as they were, in theory, to be provided for and protected by their husbands. Yet adhering to the widely accepted and long-established theory of coverture, a central tenet of colonial marriage, was highly problematic for many eighteenth century Newporters.

It was often difficult for common seamen to provide adequate security for their families. Of these "Jack Tars" Jesse Lemisch has written that "there were many... in the colonial period... who left the land in flight and fear, outcasts, men with little hope of success ashore."11 Few mariners appear to have thrived financially in their occupation. Elaine Forman Crane suggests "[a]nother reason for the growing number of poor [in Newport] may have been related to seamen's wages, which appear to have followed the Philadelphia pattern between 1763 and 1776, and according to various accounts were, on the whole, even lower than wages in Philadelphia."12 "Newport's greatest single group of impoverished residents," Sheila Skemp asserts, "was... sailors who arrived in port and simply stayed on because they were sick, wounded, lame or even dying."13 Compounding the problem of supporting the family for mariner husbands was the fact that they were physically absent not only from the home, but from the entire town for prolonged periods of time. As wives well knew, under these circumstances the support of a husband could prove hopelessly unattainable.

\footnotetext{
10 Riley, Glenda, Divorce: An American Tradition, (New York, N.Y.: Oxford University Press, 1991), 20.

${ }^{11}$ Lemisch, Jesse, "Jack Tar in the Streets: Merchant Seamen in the Politics of

Revolutionary America," The William and Mary Quarterly, 3rd Series, Vol. XXV (July 1968), 377.

12 Crane, A Dependent People, 65.

${ }^{13}$ Skemp, A Social and Cultural History of Newport, Rhode Island, 117.
} 
With her husband Joseph at sea, Mary Brown herself resolved to sublease the couple's dwelling to Timothy Wetherel for forty pounds "by reason she could get a rume Cheaper in another place."14 Mary's decision suggests a realization on her part that, with Joseph away, she could not hope to subsist without generating some income on her own. By renting a less expensive place, thus cutting her expenditures, and leasing out their dwelling, thus producing new income, Mary acknowledged the reality that Joseph would not be able to support her. Like most mariners' wives, she understood that she would have to provide financially for herself, despite the fact that she was married. Lisa Norling's investigation of another eighteenth century sailor's wife, Lydia Almy of Smithfield, Rhode Island, reveals a similar pattern. With her seafaring husband Christopher away, Lydia "earned cash by taking in an occasional boarder and tanning skins to sell, and she expressed no sense of conflict over or inappropriateness concerning her forays into financial management and market production."15 Baller has found of Marblehead women that "[w]ith their husbands at sea, they assumed responsibility for child-rearing and household management." 16 These women became decisionmakers not necessarily by choice, but certainly by circumstance. Ironically, the very nature of their marriages did not generally allow mariners' wives to submit in practice to marital coverture. Thus many such women regularly lived in a state of quasi-independence, married yet often living lives similar to other Newport women, like single women and widows, subsisting outside the institution of marriage. And the periodic autonomy mariners' wives could expect within their marriages was ever in danger of becoming permanent

\footnotetext{
14 Barsheba Loveland $v$. Timothy Wetherel, RIICCP case file, May session, 1750.

15 Norling, "How Frought With Sorrow and Heartpangs," 426.

${ }^{16}$ Baller, "Kinship and Culture," 295.
} 
should (as all too frequently began to happen by the mid-1700s) their seafaring husbands fall victim to an unforgivìng ocean.

"It is hardly surprising in a community where men earned their living by the sea," writes Elaine Forman Crane, "that the sea extracted a heavy toll in return."17 Indeed it did. So conscious were sailors about the hazards of their occupation that many drew up their wills just prior to departing for voyages. And frequent were visits to the town council by newly widowed mariners' wives in order to confer over their deceased husbands' estates. One mishap could widow several women. In September of 1744, Newporters John Gidley and Captain Sueton Grant were surveying their ship's cargo in port when a cask of gunpowder ignited and exploded. "The forementioned gentlemen were all blown out of the Chamber [of the ship] different ways to a considerable distance, with their clothes all in a blaze, and Very much scorched in the head, face, hands and legs..."18 Neither man long survived the accident, yet both left behind wives and children. Wartime privateering produced its fair share of widows as well. Sarah Downer lost her husband Captain John Downer late in the French and Indian War when he was killed in an engagement with a French privateer. Many widows remarried. Others, like Mary Carr, widowed in 1765, and Isabel Marchant, widowed in 1749 when her husband died on a voyage to the West Indies, did not. Wives might not know for some time the fate of their husbands on the high seas and weeks, even months, could pass before the women were informed of their widowhood. Again, in such instances their legal status was at odds with their condition. In fact, when the men were at sea for extended periods of time wives themselves could be unsure of their marital status.

17 Crane, A Dependent People, 69.

18 Manuel, Elton, Grant Families of Newport, (Newport Historical Society, 1990), note No. 1. 
Leaving his wife behind in Newport, Samuel Cranston set sail for the West Indies in $\mathbf{1 7 5 6}$ to carry out business transactions. He never arrived. Off the Florida Keys his vessel was set upon by pirates and Cranston taken prisoner. Seven long years passed and his wife supposed Cranston had perished in the Caribbean. Assuming her widowhood, she accepted a marriage proposal and in 1763 was preparing to remarry when Samuel finally returned to Newport. ${ }^{19}$ The plight of the "widow" Cranston illustrates the strains seafaring placed on the institution of marriage in Newport and suggests the difficulties both men and women could experience in such marriages. "Without confirmation, one could never be certain of a catastrophe at sea which would release a woman from her legal restrictions as a feme covert."20 "It is little wonder," writes Sheila Skemp, "that there were so many sailors from Newport who were lost at sea, never to be heard from again, that the General Assembly was forced [in 1744] to initiate special legislation giving their wives the power of attorney after they had been missing for three years."21 Marriage in eighteenth century Newport was clearly physically, emotionally, and legally fluid. Husbands and wives were frequently separated and reunited; feme covert women often behaved out of necessity as if they were feme sole; and wives could quickly become widows at any age. Instability was a common characteristic of Newport marriages by mid-century. Moreover, married women in the seaport were more often exhibiting a de facto autonomy at odds with the conventional notions of marriage that were to structure the identity of men and women and inform their interactions with one another. Rather than establish the husband as

\footnotetext{
${ }^{19}$ see Bain, June, "A Tale of Two Husbands," Yankee (September 1960), 64.

20 Crane, A Dependent People, 73.

${ }^{21}$ Skemp, A Social and Cultural History of Newport, Rhode Island, 123.
} 
the locus of authority, these marriages diffused authority and blurred gendered distinctions within the institution.

While the urban, commercial nature of Newport promoted de facto autonomy within marriage, it also enabled larger numbers of women to subsist outside the institution of marriage by structuring the economy so as to enable feminine labor to acquire the monetary valuation increasingly needed to avoid dependency on and debt to others. Edmund Morgan notes the political connotations of debt for colonials: "Whenever debt brought a man under another's power, he lost more than his own freedom of action. He also weakened the capacity of his country to survive as a republic."22 By contrast, the woman was expected to enter into a state of dependency by marriage, yet in the emerging economy could avoid the economic pressure to do so through the pursuit of profit. Indeed, in her study of remarriage patterns in early nineteenth century Newburyport, Massachusetts, Susan Grigg suggests that among the seaport's women personal affection and desire may have been as important as economic need or physical opportunity in the decision to remarry. ${ }^{23}$ Still, the means of economic pursuit for women were informed by colonial gender constructs.

In his analysis of eighteenth century American seaports, Jacob Price has emphasized the significance of service-oriented occupations for men in the employment structure of colonial cities. Though the creation of such jobs as innkeepers, teachers, butchers, shopkeepers, barbers, and the like were contingent, Price argues, on developments in other sectors of the local

\footnotetext{
22 Morgan, Edmund, "Slavery and Freedom: The American Paradox," Colonial America ed. by Stanley N. Katz, John M. Murrin, and Douglas Greenberg, (New York, N.Y.: McGrawHill, Inc., 1993), 267.

${ }^{23}$ see Grigg, Susan, "Toward a Theory of Remarriage: A Case Study of Newburyport at the Beginning of the Nineteenth Century," Journal of Interdisciplinary History, Vol. VIII, No. 2 (Autumn 1977): 183-220.
} 
economy like external trading activities and manufacturing, in colonial cities service-sector vocations accounted for more male employment than any other area of the economy. "In general, it seems safe to say that, in all substantial colonial towns, the service sector broadly conceived accounted for around 50 percent of the employed adult male population."24 Though he includes little discussion of women in his analysis, Price's findings are significant in understanding the relationship of Newport women to the city's economy.

Colonial social construction of gender roles dictated that women be handmaidens. To the woman fell the tasks of service: cooking, cleaning, laundering, mending, midwifery, child care. Women were ever reminded that they should "Let your Desire be to please all Men honestly."25 And of wives men were taught that "To make your happiness compleat, Be still her chiefest aim."26 As such, the association of colonial women with service could actually promote greater female activity in a service-oriented economy. Price's findings suggest that such occupations were clearly on the rise by the mid-1700s, affording colonial women greater opportunities to utilize their role as handmaiden to eke out an existence on their own.

One of the most common methods of economic subsistence for Newport women in the $1700 \mathrm{~s}$, the taking in of boarders, was so common precisely because of the urban, cosmopolitan nature of Newport. On any given day, scores of visiting mariners, merchants and tradesmen, and even an occasional dignitary like George Berkeley would dock at one of Newport's many wharves. Their need for shelter and food created a demand for a service Newport's women were quite able and willing to provide. In town to

\footnotetext{
${ }^{24}$ Price, Jacob M., "Economic Function and the Growth of American Port Towns in the Eighteenth Century," Perspectives in American History, Volume 8 (1974), 133.

25 Newport Mercury, February 28, 1763.

${ }^{26}$ Newport Mercury, March 12, 1764.
} 
ply his trade in 1764, the English oculist and surgeon Dr. Stork advised prospective patients to visit him at Mrs. Searing's dwelling near the Trinity Church, where he was to board for the next three to four weeks before moving on. ${ }^{27}$ The way in which Newport women could, and did, play upon gender distinctions to generate their own revenue is suggested by the advertisement Abigail and Elizabeth Cole jointly placed in the Newport Mercury early in the summer of 1759 .

Available evidence suggests that Abigail and Elizabeth were sisters and that both were single women. Together they succeeded in carving out for themselves reasonably comfortable existences in the port city by attending to men's needs. In June of 1759 they took out an ad to "acquaint such GENTLEMEN who have Occasion for Private Lodgings" that they were moving their business to a new location which promised "a Number of genteel Apartments for the Accommodation of Gentlemen."28 That the ad was addressed to a male audience was no coincidence. Women boarded, but men did so more frequently, in greater numbers, and were generally able to rent at higher rates. The Coles understood this and recognized also that their gender proved no barrier to their search for a male clientele. The sisters seem to have experienced some success in their boardinghouse operations, for in 1774 when the census-takers came around they still maintained their own place. Elizabeth is listed in that census as a head of household with five others attached to her residence, one white woman over sixteen (presumably Abigail), one Native American, and three blacks. The following year's tax list found Abigail and Elizabeth listed together as the sixth-highest taxed women in the city at nine shillings three pence.

27 Newport Mercury, February 20, 1764.

28 Newport Mercury, June 5, 1759. 
Though boarding was by no means unknown to rural areas, it proved more viable for more women in an urban environment. Newport in the eighteenth century was a dense, compact city. Bruce Daniels estimates that Newport's density in 1774 was 1,196 persons per square mile. In contrast, Providence, the colony's second largest community, had a density of 239 persons per square mile. ${ }^{29}$ Elaine Forman Crane believes that the compactness of Newport affected housing availability. "Whether there were 1,500 or 1,800 families in the community, there clearly were a great many more families than houses. Under these circumstances, house sharing must have been a common phenomenon." 30 As Newport grew to become the fifth largest city in the colonies, the increasing mobility and density of its population provided a substantial demand for lessors. Many widows took advantage of this situation to provide support for themselves after their husbands' deaths.

Carole Shammas has noted of Philadelphia on the eve of the Revolution that "[o]nly a very small percentage of women boarded and most of them were married or widowed." 31 Indeed, in Newport the most typical boarding arrangement was the leasing of a portion of the widow's dwelling to a single man or a man and his family. Sometimes entire estates were rented. The complexities of boarding in a seaport are evidenced by the case of Barsheba Loveland. Loveland, a Newport widow, leased a part of her residence to Joseph Brown and his wife Mary at a cost of forty pounds a year. However, when Joseph went to sea, Mary moved out and sublet the space to Timothy Wetherel. Not long afterwards, Wetherel and Loveland quarreled their way into court over boarding privileges. The terms of boarding agreements were

\footnotetext{
${ }^{29}$ see Daniels, Bruce C., Dissent and Conformity on Narragansett Bay: The Colonial Rhode Island Town, (Middletown, Conn.: Wesleyan University Press, 1983), 54.

30 Crane, A Dependent People, 71.

31 Shammas, Carole, "The Female Social Structure of Philadelphia in 1775," The Pennsylvania Magazine of History and Biography 107 (January 1983), 82.
} 
occasionally manipulated by widows so as to procure work from their lessee(s) and thus save on expenses. For example, the widow Judith Clarke agreed in 1755 to lease one William King a plot of her land "containing by Estemation Seventeen Square Rods and the House thereon" upon the condition that he 1) fence in the lot immediately "with a good and Sufficient Fence according to Law" and 2) "fitt up and mend said house upon said Lott by Putting two New Cells to the Easternmost part and with Shingling said Easternmost part and otherwise to mend and do all Needful Repairs..." and 3) to pay a yearly rent of five cords of wood in two installments of two and a half cords every six months. ${ }^{32}$ Failure to meet contractual obligations could, and periodically did, land the men in court. In November 1760, Mary Barney sued Thomas Crossing for one hundred pounds in back rent. ${ }^{33}$ The same session of court saw Phebe Battey likewise sue David Richard, Jr., and Sarah Heffernan bring suit against Jeremiah Heffernan for failure to pay rent. ${ }^{34}$

In writing his now-famed novel The House of the Seven Gables, Nathaniel Hawthorne in 1851 drew on the long tradition of New England women as boardinghouse keepers. The character Holgrave enters the novel as a boarder of the elderly Hepzibah Pyncheon, who possesses the House. Hepzibah, an "old maid" as Hawthorne describes her, had found poverty "treading on her heels for a lifetime" and her circumstances dictated that "[s]he must earn her own food, or starve!"35 Tellingly, Hawthorne also has Hepzibah keep shop for subsistence. "This business of setting up a petty shop," he concludes, "is almost the only resource of women in circumstances

\footnotetext{
32 Judith Clarke v. Joseph Hull, November 1755, RIICCP case file.

${ }^{33}$ Mary Barney v. Thomas Crossing, RIICCP Record Book, Vol. F, 360.

34 RIICCP Record Book, Vol. F, 348 and 365.

35 Hawthorne, Nathaniel, The House of the Seven Gables, (New York, N.Y.: Bantam Classics reprint, 1981), 27.
} 
at all similar to those of our unfortunate [Hepzibah]."36 Here too the author drew upon observation and historical understanding to shape his novel. Carole Shammas has found that in colonial Philadelphia "[r]etailing was the most common occupation for female household heads." 37 Patricia Cleary similarly argues that "women traders in eighteenth-century cities like Philadelphia and New York ran highly visible shops from which they sold imported luxury wares." ${ }^{38}$ In Newport, too, shopkeeping became an increasingly viable vocation for women as the city geared its economy toward trade and commerce.

"Retail shops," Sheila Skemp has observed of colonial Newport, "were becoming increasingly prominent in the 1720 s and $1730 \mathrm{~s}$, an indication that business was booming and effective demand was increasing." 39 Most often, women acquired shops through men. Of late eighteenth century New York City, Christine Stansell has concluded, "Widowhood was a common road to female proprietorship."40 It was not at all unusual for the widow of one of Newport's many shopkeepers to attempt to carry on the business after his decease. For example, following the untimely death of her husband Sueton, Temperance Grant ran the family's shop with the help of relative Patrick Grant. The widow Sarah Rumreill, a long-time member of Ezra Stiles's Second Congregational Church, carried on a successful shop to which many Newport men were indebted. Robert Petty, a local tailor, often purchased the appliances of his trade from Rumreill. Cordwainers, shipwrights, butchers, distillers, and house carpenters all frequented her store. Sarah's success was

\footnotetext{
36 Ibid., 27.

37 Shammas, "The Female Social Structure of Philadelphia in 1775," 75.

38 Cleary, "'She Will Be in the Shop,"' 182.

39 Skemp, A Social and Cultural History of Newport, Rhode Island, 126.

40 Stansell, Christine, City of Women: Sex and Class in New York, 1789-1860, (Urbana, Ill.: Illinois University Press, 1987), 14.
} 
not overlooked by the town council. In 1772 , the council taxed her fourteen pence, a high rate for a woman and indicative of her relative prosperity.

Exactly how these women were able to transact and interact in a profession that was still male-dominated and required at least a modicum of financial understanding is unclear. It seems likely, Lisa Wilson has concluded, that such women had been involved in the operations of the shops long before they were widowed. "Widows' behavior gives us good reason to believe that these women were familiar with the economic affairs of their families before their husbands' deaths." 41 Evidence also indicates that other family members, particularly sons, aided widows in tending to all the necessary details of shopkeeping. Sarah Rumreill's son Thomas, who also tended his own shop, seems to have done at least some of his mother's bookkeeping for her. When she sued the tailor Robert Petty in 1760 for failure to pay his debts, she presented to the court a detailed list of goods sold to Petty between 1758 and 1759 and their calculated value, which was clearly the work of her son. At the bottom of the compilation, Thomas had written "Errors Excepted For my Mother."42

That widows were helped by relatives should not be construed as indicative of their incompetence. "The evidence in Philadelphia," writes Lisa Wilson, "suggests that men often trusted their wives' economic skills and that women deserved this confidence." 43 Indeed, the Newport shopkeeper Caleb Gardner's will of November 2, 1761 suggests the same. Caleb clearly wanted his wife Elizabeth to subsist comfortably on her own after his death. To her he left much of their dwelling house and his shop, access to the garden, the

\footnotetext{
41 Wilson, Lisa, Life After Death: Widows in Pennsylvania, 1750-1850, (Philadelphia, Pa.: Temple University Press, 1992), 115.

42 Sarah Rumreill v. Robert Pettys, May 1760, RIICCP case file.

43 Wilson, Life After Death, 119.
} 
yard "for Laying of firewood," the "Well and Pump for fetching of water," as well as "personal items necessary for housekeeping." The shop in particular he saw as a vehicle toward her future comfort. Yet Caleb's concern for his son and his family also influenced the character of his bequest, so he left it up to his wife and son together to "Improve my Whole Estate... in carrying on shopkeeping... the Better to Enable My Ex[ecutors] [one of whom was Elizabeth] to Pay and Discharge My Debts [and] my said Wife Elizabeth and my Son Caleb and his family to have... Comfortable Subsistence out of the Improvement of my Said Estate." That Gardner felt his wife capable of carrying on his business and desired her to do so are both reflected in her inclusion in the provision regarding the shop. Moreover, the will reveals Caleb's faith that shopkeeping in Newport was economically viable enough to pay off his debts after his death yet still support both his widow and his son's family. Finally, Caleb Gardner's will suggests that a man's concern for his family may also have helped propel women into the public sphere of business. ${ }^{44}$ Indeed, Lisa Wilson has discovered a parallel example of such familial concerns among eighteenth century Philadelphians. When the cabinetmaker Thomas Bryan wrote his last will in 1799 he, like Caleb Gardner, perceived his business as the key to the joint maintenance of his wife and children after his death. "I will \& direct," he declared, "that the said benches \& tools shall be still kept and used by him [his son] in carrying on the trade \& business jointly with his mother for the better support \& bringing up of my younger children." 45

The influence of colonial gender constructs is evident in the economic pursuits of Newport's women out of wedlock. As noted earlier, the role of the

\footnotetext{
44 see Newport Town Council Record Book \# 13 (1760-1763), 129.

45 as quoted in Wilson, Life After Death, 115-116.
} 
colonial woman as handmaiden to the colonial man allowed women to engage in service transactions with men that had the potential to erase an economic need for marriage or remarriage. Catering to gentlemen also meant the possibility of generating greater income than serving women, as in Newport "[w]omen as a group were considerably less affluent than men..."46 As a result, many women geared their livelihoods toward occupations that would afford them the greatest potential revenue, service-oriented activities aimed primarily (though not exclusively) at the male population. Though Abigail and Elizabeth Cole are prime examples of this phenomenon, other telling examples exist as well.

On April 20, 1752, Major John Roger's wife appeared before the Newport Town Council requesting a retail liquor license for their household. John was away, and his wife had concluded that she would need to produce income herself in order to get by. Her choice of service would give her a predominantly male clientele, for though women did consume alcohol they were less likely to do so than men. Yet, not coincidentally, women frequently retailed spirits. In his investigation of colonial New England alehouse culture, a culture particularly prevalent among urban seaports like Boston and Newport, Bruce Daniels concludes that "a substantial number of tavernkeepers were women."47 And Douglas Good has discovered of Newport in the 1720s that "[t]he Town Council had regularly met at Mary Nichol's inn."48 Available evidence suggests too that female tavern keepers were not alone in tailoring their livelihoods toward a male customer base.

Several colonial Newport women are listed in the records as glovers. George H. Richarson's scrapbook contains a list of six such women, including

46 Crane, A Dependent People, 71.

47 Daniels, Bruce C., Puritans at Play, (New York, N.Y.: St. Martin's Press, 1995), 153.

48 Good, "Colonials at Play," 10. 
a Mrs. George Sherman who "says 12 pair was a smart day work from morning until 9 o'clock at night."49 His list, however, seems far from exhaustive. Though the prevalence of women glovers is uncertain, there is evidence that suggests these women may have also directed their business toward the city's men. Richardson made note that Sarah Sherlehy, a late eighteenth century Newport glove-maker, "makes gloves for Capt. Elnathan Hammond."50 The will of the widow Sarah Wright is also instructive in this regard.

When she died in December of 1760, "old" Sarah Wright left no direct indication of how she survived widowhood economically, yet she seems to have adequately provided for herself. Among the possessions of her estate were found a clock and case worth two hundred pounds, china bowls, and, interestingly, nine ounces of gold valued at one hundred pounds an ounce. She also left behind her slave Belinda, whom Sarah requested be manumitted at death and given "her Bed and Everything that belongs to it." 51 How Sarah may have provided for herself and Belinda is intimated by the presence in her estate's inventory of twenty-one pair of men's gloves and four pair of women's gloves. Since a widow would presumably have little need for so many gloves, it seems likely that, perhaps with the aid of Belinda, she made or at least retailed them. And the fact that Sarah possessed so many more men's gloves than women's indicates that, like others, she catered to a primarily male clientele.

An even more difficult occupation to evidence, prostitution, is also indicative of the way many female services served men's wants and desires. Prostitution certainly existed in eighteenth century Newport; in fact, it may

49 George H. Richardson Scrapbook, Newport Historical Society..

50 Ibid.

51 The will of Sarah Wright, Newport Town Council Record Book, 1760-1763, Book 13, 69. 
have even thrived. Both Douglas Good and Elaine Forman Crane have documented its presence in the city. Crane contends that "[a]lthough prostitution was illegal by virtue of the laws governing fornication, brothels flourished."52 Similarly, Good concludes that "[p]rostitutes plied their trade among the respectable as well as the army and on the waterfront." 53 Individual cases of prostitution are often masked and only suggested in the records. In May 1749, for instance, Benjamin Dunham was brought before the Court of General Sessions "charged with having the carnal knowledge of the Body of Mary Hill of said Newport Singlewoman at several Times and that the said Mary Hill is with Child by him... which when born will be a Bastard."54 Curiously, several years later, in 1757, James Searle, "an Infant under the age of twenty one years," was likewise "chargd by Mary Hill of said Newport Singlewoman with begitting her with Child."55 At least in part, the nature of Mary's relationships with the two males was clearly sexual, but whether or not she was, or would have considered herself, a prostitute remains unclear. To some of Mary's contemporaries, however, there was certainly a prostitution problem in Newport. "Deborah Meanwell" argued in 1769 that the lack of concern "for the safety or liberties of their country" evident among Newport's young men stemmed from the fact that they were frequently out "drinking, gambling, and whoring" their nights away. ${ }^{56}$ The difficulties a colonial woman faced without the aid of a husband could convince her to suspend her sexual propriety if doing so proved financially beneficial.

\footnotetext{
52 Crane, A Dependent People, 75.

53 Good, "Colonials at Play," 13.

54 see General Sessions Record Book, May 1749, 23.

55 see General Sessions Record Book, May 1757, 88.

56 Newport Mercury, May 29, 1769.
} 
As noted earlier, when the widow Sarah Wright drew up her last will and testament she included a provision that would manumit her slave Belinda upon Sarah's death. Wright's provision reveals the complexities of the relationships between the white women of Newport and their slaves. The widow chose to free Belinda rather than pass her on to a friend or relative, indicating a belief by Wright that her slave deserved freedom. Historians have noted that in general women were much more likely to manumit slaves in wills than were men. That the widow made Belinda's freedom contingent upon her own death, however, suggests that Belinda was too valuable to be freed while Wright was still alive and trying to endure widowhood. Indeed, the slave presence in Newport was a potential source of physical, emotional, and financial help to the area's widows. Still, although in her will she gave to the widow Jane Wright (a relative by marriage) "my feather bed... and, one pillow with a white cover...," Sarah declined to bequeath Belinda as aid..$^{57}$ As death approached, Sarah had obviously concluded that bequeathing Belinda her freedom was more just than keeping her in bondage to help another; yet she had previously been willing to subjugate the slave woman to fulfill her own needs. The inconsistency of Sarah Wright's attitude about Belinda suggests the potential tension female slave holders in colonial Newport faced between moral, emotional, and economic needs.

Census records indicate that in 1774 almost twenty-five percent of Newport households headed by white women included one or more Native Americans or blacks. As there were few free blacks or Native Americans in Newport at the time, it can be assumed that most were slaves. New England slaves generally lived in close proximity to their masters. William Piersen writes, "Since northern slave owners rarely held enough bondsmen to permit

\footnotetext{
57 The will of Sarah Wright, Newport Town Council Record Book, 1760-1763, Book 13, 69.
} 
the expense of separate living quarters for the races, common residence during the more domestic hours reinforced the proximity of workday relationships." ${ }^{8}$ Joseph Peter Parker adds that "[t]he slave quarters were usually in the garrets of houses or in various outhouses on the larger estates." 59 The resultant familiarity between slave and slave holder in New England bred "emotional attachments within Yankee families between white and black [that] were a complex and contradictory fabric, interweaving formal expectations of social roles with coarser strands of racial prejudice and finer threads of human affection." 60 Still, the relationship was ever-grounded in economic exchange. "It was primarily to furnish laborers that Negro slaves were brought into New England."61

Historians have generally been slow to appreciate the significance of slavery in allowing white women to maintain themselves outside of marriage. Lynne Withey has described the impact of slavery on household size in Newport, noting that the discrepancy in size between households with slaves in 1774 and those without them was seven-tenths of a person. She suggests that only the wealthy benefited from the presence of slaves in Newport. "Slaves were most common in Newport," she writes, "where they were servants in wealthy households." 62 There is indeed a strong relationship between wealth and slaves in colonial Newport, even among women heads of household. Elaine Forman Crane estimates that only around three and a

\footnotetext{
58 Piersen, William, Black Yankees, (Amherst, Mass.: The University of Massachusetts Press, 1988), 25.

59 Parker, Joseph Peter, "Slavery in Rhode Island," (Master of Arts thesis: University of Rhode Island, 1962), 28.

60 Piersen, Black Yankees, 32.

61 Greene, Lorenzo Johnston, The Negro in Colonial New England, 1620-1776, (Port Washington, N.Y.: Kennikat Press, Inc., 1966), 101.

62 Withey, Lynne, "Household Structure in Urban and Rural Areas: The Case of Rhode Island, 1774-1800," Journal of Family History, Vol. 3 (1978), 40.
} 
half percent of Newport taxpayers in the late colonial era were women.63 The 1775 tax list, for instance, contains the names of only thirty-four female taxpayers, women with enough wealth to justify taxation. Of these women, well over half (between fifty-five and sixty percent) owned slaves. In fact, together they held approximately half of the slaves owned by female heads of household in the 1770s, which numbered nearly three hundred women. Many of the women were widows and presumably inherited their slaves from their husbands. Yet it would be a mistake to construe the slaves' presence in these women's estates as simply reflections of their deceased husbands' wealth. There were slave-owning women who did not appear on the tax list, and though certainly helpful, inherited wealth was no assurance that a widow could maintain herself economically over the years. Widowhood was often synonymous with poverty in colonial America and a deceased husband's debts could financially ruin his wife, as could her own mismanagement. "With a husband's death, a widow was immediately beset by legal, financial, and family problems."64 That a woman like Sarah Rumreill who had been widowed for over twenty years could yet appear on the 1772 tax list is as much a testament to the way she handled her husband's wealth as it is to the husband's wealth itself. Evidence suggests that the utilization of slaves afforded Newport women a level of subsistence they might otherwise have been unable to maintain.

Historians such as Lorenzo Greene and William Piersen have noted the wide variety of tasks New England slaves were trained to perform by their masters. "The majority of New England blacks," writes Piersen, "found themselves in service to masters who could afford no more than one or two 
slaves to aid them in general housework and the running of a small farm or business." 65 Training one's slave in a particular craft was socially acceptable and thus northern slaves were often familiar with a variety of occupations, including (but certainly not exclusive to) tanning, smithing, carpenting, tailoring, weaving, baking, and butchering. Greene contends that "[i]n the many homes employing slave labor, Negro women served as cooks, laundresses, maids, nurses and as general household workers, but they were also trained in domestic arts."66 Such slaves directly contributed to their masters' economic well-being.

Before his death, Amy Weeden's husband William, a painter, had done much work for Captain Matthew Cozzens, including painting his chaise, the inside of Cozzens's house, and his sloop the Herring. After William's death, Amy continued to transact business with Cozzens by lending him her slave. For eleven days worth of her slave's painting, Cozzens gave Amy eight yards of Irish linen. Not feeling adequately compensated, Weeden took him to court and was awarded three pounds lawful money of Rhode Island for the balance owed her. Cozzens appealed the decision but eventually dropped the suit. Amy's slave had probably been trained to paint by her husband William and had likely aided him in such time-consuming projects as the painting of Cozzens's ship. Shiela Skemp notes an incident in which "Mary Updike... sent slaves to work for [Henry] Ward in return for the goods she purchased from him."67 Lorenzo Greene has concluded that such "hiring out of slaves seems to have been a general practice."68 Yet hiring out was not the only

\footnotetext{
65 Piersen, Black Yankees, 43.

66 Greene, The Negro in Colonial New England, 110.

67 Skemp, A Social and Cultural History of Newport, Rhode Island, 383.

68 Op. Cit., 120.
} 
means by which Newport women could use slaves to help maintain themselves financially.

Slaves could be of particular help to shopkeepers. Goods had to be hauled to and from the wharves and warehouses to the shops, then stored and stocked; the shops themselves needed periodic cleaning; and shopkeepers could always use help tending to customers. Lorenzo Greene has discovered an instance in which "Mesheck, the slave of Colonel Hinsdale of Deerfield, Massachusetts, operated for his owner at Deerfield a store located opposite the house of George Sheldon, the town's historian."69 It seems likely that Sarah Rumreill's three slaves were in some way involved in the operation of her successful shopkeeping venture. Similarly, Abigail and Elizabeth Cole, the boardinghouse owners noted earlier, assuredly utilized their four slaves to carry on their business as well. In addition to their boardinghouse, Elizabeth and Abigail sold dry goods, which probably extended the tasks expected of their slaves. The staymaker Hannah Allen had only one other resident in her home, a Native American slave who, if she did not assist Hannah in her trade, at least probably attended to other chores which freed time for Hannah to devote to her occupation. Belinda may have done the same for the glover Sarah Wright. It is unlikely that these women's slaves were merely idle residents in the home. Such was not the nature of slavery in New England. Slaves "were not being trained to be the equals of white New Englanders, only to be useful and accommodating slaves."70

Slaves were valuable commodities in eighteenth century New England and, as widowhood and spinsterhood were often financially precarious states of existence, could consequently be fiercely guarded by the city's women. In

69 Ibid., 118.

70 Piersen, Black Yankees, 37. 
1763, for example, the widow Hannah Wanton filed suit against John Rogers, charging that Rogers "did take and carry away from the Pl[aintiff] a Negro Boy named Primus of the value of Two Thousand pounds Money \& to the Pl[aintiff] belonging..."71 Hannah's assertiveness paid off. She won the case. The widow Mary Mullin's slave Doppo was prosecuted in 1762 for assaulting the merchant Isaac Polock; Doppo allegedly grabbed Polock "by the Throat and did Scratch the said Isaac \& violently Shake him and did threaten that he would ------ him."72 Though the record is silent about the reason for Doppo's contact with Polock, it is possible that he was transacting business for Mullin. Historians have illustrated that some slaves were given responsibility for business transactions by their owners. "By demonstrating a marked interest and ability in discharging their masters' affairs, some Negroes were rewarded with positions of trust and responsibility."73 If she was able, it is likely that the widow paid Doppo's forty pound fine plus cost of suit. Mary Brett took Temperance Grant to court in 1754 over two slaves, Mole and Cato, whom she argued were the property of her husband John at the time of his death. The case stretched through several sessions of court before it was resolved, as both plaintiff and defendant utilized their rights of appeal.

Slave ownership very much involved women in public negotiations with the city's men. Whether it was to answer for a slave's misdeeds, to hire out slave labor, to buy or sell a slave, or to enter a runaway slave ad in the newspaper, slavery drew mistresses into the courthouses, warehouses, wharves, and printing shops. As slaves like Hannah Wanton's Primus or

71 Hannah Wanton v. Josiah Rogers, May 1763, RIICCP Record Book, Vol. G, 3.

72 Rex v. Doppo, General Sessions Record Book, May 1762, 145.

73 Greene, The Negro in Colonial New England, 117. 
Mary Mullin's Doppo could be valued at up to one thousand pounds, ${ }^{74}$ a runaway slave represented a severe economic blow to women as both lost capital and lost labor. As such, it was not uncommon for colonial mistresses to traipse into the printing shops with advertisements offering rewards for the return of their fugitive slaves. Nor was it unknown for women to advertise the sale of their slaves, again immersing themselves in public financial dealings. "Transactions involving the sale of slaves were usually executed through regular bills of sale and were witnessed, signed, and recorded just as was the sale of other property."75 Sale was not an uncommon method of ridding oneself of an uncooperative slave. Moreover, the sale of a slave could yield needed finances for a woman should her situation deteriorate. In this regard also, it was financially beneficial to possess skilled slaves. "At the slave market artisans invariably sold for twice as much as unskilled field hands."76 Not surprisingly, then, when the Newporter Amy Weeden sought to sell a slave of hers in 1765 , she was sure to emphasize that the "likely Negro Man... is allowed, by the best Judges, to be a very good Painter."77 The extra money garnered by the sale of a skilled slave could be of great importance, as by the mid-eighteenth century a clear characteristic of Newport was the growing number of poor inhabiting the seaport.

Bruce Daniels argues that the rising poverty in the city "resulted primarily from economic forces operating beyond anyone's direct control."78

\footnotetext{
${ }^{74}$ see, for example, the appraisal of James Collins's estate in the Newport Town Council Record Book, 1760-1763, Book 13, pg. 91. Collins owned several slaves ranging in value from 1,000 pounds for "one Negro Man named Bristol" to 200 pounds for the young slave girl Yiolet.

75 Greene, The Negro in Colonial New England, 45.

76 Stavisky, Leonard, "The Origins of Negro Craftsmanship in Colonial America," The Other Slaves: mechanics, artisans, and craftsmen, ed. by James E. Newton and Ronald L. Lewis (Boston, Mass.: G.K. Hall \& Co., 1978), 186.

77 Newport Mercury, February 18,1765 .

78 Daniels, Bruce, Dissent and Conformity on Narragansett Bay: The Colonial Rhode Island Town, (Middletown, Conn.: Wesleyan University Press, 1983), 78.
} 
Increasing population and density, the fluctuating Atlantic economy which "swung erratically between prosperity and depression," and increasing involvement in Britain's colonial wars all played a part in bringing about the situation. ${ }^{79}$ Though not as severely, it seems clear that Newport was enduring some of the same growing pains that Gary Nash has described for other northern seaports... increased poverty, indebtedness, and widowhood..$^{80}$ Indeed, the ranks of indigents included a number of widows. Lynne Withey estimates that between 1700 and 1780 the resident poor in Newport included thirteen widows. ${ }^{81}$ These women needed varying degrees of help. In March of 1752, Benjamin Jeffers's widow was provided with half a cord of wood paid for out of the town treasury. ${ }^{82}$ "Anywhere from about one-tenth to one-fourth of Newport's poor," Withey estimates, "received this type of support in the period before the Revolution." ${ }^{83}$ Still, there were others like Elizabeth Thurston who needed greater aid. "The Town Council totally supported Widow Elizabeth Thurston for a number of years." ${ }^{84}$ As previously mentioned, in addition to the emotional trials occasioned by the loss of a loved one, the widow frequently had to endure the claims of her husband's creditors. For some women, satisfying the claims could be quite distressing and could leave them in dire straits.

Sarah Shaw's husband Lemuel had a history of trouble with the law. In 1748 he was prosecuted for the illegal selling of rum, probably without a license. A few years later he was ordered to pay a ten pound fine for illegal

\footnotetext{
79 Ibid., 79.

80 see Nash, Gary, The Urban Crucible: The Northern Seaports and the Origins of the American Revolution, (Cambridge, Mass.: Harvard University Press, 1986).

81 see Withey, Lynne, Urban Growth in Colonial Rhode Island, (Albany, N.Y.: State

University of New York Press, 1984), 134.

82 Newport Town Council Record Book, 1750-1755, Vol. 11, 41.

83 Op. Cit., 57.

${ }^{84}$ Skemp, A Social and Cultural History of Newport, Rhode Island, 345.
} 
card gaming in addition to returning the money he had won. Some time in the mid-1750s, he died under incarceration, most likely in debtor's prison. Both his life and his death seem to have burdened Sarah, for not long after Lemuel's decease Sarah was sued by Abiel Cook, a man to whom Lemuel owed hundreds of pounds in money. The widow pleaded with the court that she had nothing to give, for "after the Death of Lemuel Shaw a Coat [?] with wearing apparel to the Value of about fifteen pounds old tenor of said Shaw's estate came into her possession which she laid out for the funeral Expenses of said Shaw who died in prison and that she hath not otherwise administered upon his estate..." 85 No other record of Sarah Shaw has been found, but it seems likely that she either remarried, moved in with relatives, or lived a life, like many widows, on the margins. Lisa Wilson notes of Philadelphia's widows that "[m]ost paupered widows had been the wives of men who worked in low-paying jobs, and many had themselves labored for wages during marriage in order to supplement their family's income." 86 Indeed, there is evidence that for some Newport women marriage was the cause of their distress.

Sarah Osborne, best known for her role in Newport's Great Awakening revivalism, is a prime example of a woman for whom marriage did little to foster economic security. Without the approval of her parents, the teenage Sarah married a local mariner named Samuel Wheaton and the following year bore a child by him. Tragically, Samuel would not long be able to enjoy his new family, for only two years after marrying Sarah he died at sea. Burdened with an infant son and thrust into the role of financial provider by the sudden death of her young husband, Sarah turned to school teaching as a

${ }^{85}$ Abiel Cook v. Sarah Shaw, November 1755, RIICCP case file.

86 Wilson, Life After Death, 59. 
means of support. Other Newport women also kept schools to make ends meet. In May of 1767, Mary Gardiner announced that she "Has removed to the House of the Widow King, in the Church Lane, where she continues to keep School, and teaches Reading, Writing, and all sorts of Needle Work." ${ }^{\text {87 }}$ Similarly, Elizabeth Allen, who was "Living in the Widow Bristow's House, on the Point" in 1768, proposed to operate a "School for Reading and Knitting." 88 Mary Beth Norton writes that indeed "Sarah Osborne was not alone among eighteenth-century women in her decision to support her family by teaching [as] [s] tudies based largely on newspaper advertisements have shown that numerous women, especially those who were unmarried, adopted this method of earning money." 89

Sarah's first school teaching venture lasted approximately seven years and attracted students from as far away as Providence and Stonington, Connecticut. Though historians differ over the cause, they agree that in 1741 Sarah closed down the school "and for a few months she made ends meet by serving as an assistant in a shop." 90 The following year she accepted a marriage proposal from Henry Osborne, "but soon afterward it emerged that he was heavily in debt, and everything that he and Sarah owned was sold to pay his creditors. "91 Henry's business failed and, as Mary Beth Norton asserts, he "never worked again, therefore placing the entire burden of supporting the combined families on his wife's shoulders."92 The situation left her, as she herself wrote, "a poor over Loaded weak animal crouching and

\footnotetext{
87 Newport Mercury, May 4, 1767.

88 Newport Mercury, July 4, 1768.

89 Norton, Mary Beth, "My Resting Reaping Times': Sarah Osborn's Defense of Her 'Unfeminine' Activities, 1767," Signs, Vol. 2 (1976), 518.

90 Buel, Joy Day, and Buel, Richard, Jr., The Way of Duty: A Woman and Her Family in Revolutionary America, (New York, N.Y.: W.W. Norton and Company, reissue 1995), 19. 91 Ibid., 19.

92 Norton, Mary Beth, '"My Resting Reaping Times': Sarah Osborn's Defense of Her 'Unfeminine' Activities, 1767," Signs, Vol. 2 (1976), 517.
} 
trembling inder its burden" whose only "means that Holds up our Heads above water at all is a couple of boarders."93 She also resumed teaching. Assessing her predicament, Charles Hambrick-Stowe has concluded that "poverty dogged Sarah all her life."94 Marriage clearly did not protect Sarah Osborne from the unpleasantries of life. Instead, as with other women, matrimony exposed her to them.

On March 2, 1752, Penelope Dyre appeared before the Newport Town Council and "Prayed that She might have Something Allowed Her for Support of Her Self and Children She having had no Support from Her said Husband [Charles] for Severall Years past..."95 Lynne Withey notes an instance in Newport in which "George Harris's wife herself appeared before the Council, asking them to take steps because her husband was improvidently spending all his money, leaving his family to suffer." 96 On February 4, 1760 the Town Clerk was ordered to find William Easton and bring him before the Town Council "at the Request of his wife to know whether he will allow her a Separate Maintenance."97 In 1768, Asa Letin left his wife Ann two years into their marriage only to return nine months later, collect the money she had earned trying to support herself and their young child, and depart again, never to return. Understanding that the source of her trouble was her marriage, Ann divorced Asa in 1774.98 Elaine Forman Crane argues that "women who were married to sailors often turned to the merchants for money to see them through the long months when their

\footnotetext{
93 as qouted by Ibid., 517-518.

94 Hambrick-Stowe, Charles E., "The Spiritual Pilgrimage of Sarah Osborn (1714-1796)," Church History, Vol. 61, No. 4 (December 1992), 409.

95 Newport Town Council Record Book, 1750-1755, Vol. 11, 41.

96 Withey, Urban Growth in Colonial Rhode Island, 61.

97 Newport Town Council Record Book \#13 (1760-1763), February 4, 1760 notes.

98 Divorce petition of Ann Letin, March 1774, R.I. Sup. Ct. Records, Newport District, Record Book F, 91.
} 
husbands were on a voyage." 99 For these women, marriage brought emotional pain and economic privation. "[L]ife before the loss of her husband," Lisa Wilson writes of such women, "involved desperate poverty and inadequate, dangerous housing [so that] [w]idowhood... made little change in her economic circumstances." 100

Though detailed records of the transient women on relief in colonial Newport do not exist, Lynne Withey's analysis of Newport's northern Rhode Island neighbor, Providence, contains some interesting insights as to what type of women found themselves enmeshed in the colony's poor relief system. One out of every four of Providence's transient women who received poor relief was married. 101 Withey dismisses any significance in this number, but if one considers the circumscribed and sedentary, yet protected lifestyle colonial marriage was ideally to present to women, the number of married female transients is actually surprisingly high. In early 1760 the wife of Captain John Coultas, having followed her husband to Newport, was jailed as a stranger in town and ordered to explain her presence in the seaport to the Town Council. "She Informed the Council that She is his [Coultas's] wife But Desired to Go Back to Piscataqua by the first Vessel that Goes." 102 Also surprising is the relatively few transient women Withey identified as widows receiving relief from the city. Given the close association in the colonial mind between widowhood and poverty, one might expect that widows would outnumber married women among Providence's transient poor; yet only sixteen percent of the city's transient women were widows. Similarly, Lisa Wilson has noted of Philadelphia's almshouse that "[i]n 1813, when

99 Crane, A Dependent People, 72.

100 Wilson, Life After Death, 60.

101 see Withey, Urban Growth in Colonial Rhode Island, 136.

102 Newport Town Council Record Book \# 13 (1760-1763), April 7, 1760 notes, 26. 
administrators began to keep statistics of the population by gender, widowed inmates averaged only 2 percent of the institution's female adult population."103 Single women with children constituted another sixteen percent of Providence's transient poor and eighteen percent of the resident poor women. (Such women existed in Newport as well, like Ann Hill who the Town Council judged "is Very Poor \& has 3 children [and is] to be allowed 5 [pounds] a Week till further Order."104) Withey judges the remaining fortythree percent of Providence's transient females to be single. Of these women, she concludes "Almost all were young, came from towns within a thirty-mile radius of Providence, and worked as servants or laborers." 105

Colonial Newport's poor women seem to have been a diverse lot as well. The town surely saw its share of transient women such as Mary Mason, "who says she belongs to New London," along with the mysterious Mary Brown and the deviants Christiana Renshen and Julian Woolford introduced in the previous chapter. ${ }^{106}$ Married women were not immune to economic want and neither were widows. "Perhaps you know as well as I," wrote one Newporter in the summer of 1769 to the Newport Mercury, "that there are many poor women in this Town, almost starving for Want of Employ..."107 Yet that Lynne Withey detected only 115 individual women who required poor relief from the town over an eighty year time span suggests that most women eked out an autonomous existence so that by 1774 twenty percent of the city's households were headed by women. ${ }^{108}$ And the care taken by some to delineate inheritance despite a paucity of valuable goods indicates a pride in

\footnotetext{
103 Wilson, Life After Death, 90.

104 Newport Town Council Record Book, 1760-1763, Vol. 13, 1.

105 Withey, Urban Growth in Colonial Rhode Island, 64.

106 Newport Town Council Record Book, 1700-1763, Vol. 13, 46.

107 Newport Mercury, June 5, 1769.

108 see Crane, A Dependent People, 70.
} 
their lives and their possessions as well as a desire to independently decide the distribution of their estates.

In her examination of the free women of Petersburg, Virginia, in the early nineteenth century, Suzanne Lebsock has discovered that for women "relative poverty was less likely to prove an obstacle to writing a will" than it was for men. ${ }^{109}$ Moreover, they could be more meticulous than men concerning the distribution of their estates. Lebsock attributes such distinctions to differing value systems between the city's men and women. Because the measure of a man was his wealth, she argues, men who were financially troubled were reluctant to document their humiliation and would instead hold off in the hope of better days ahead. By contrast, women were less concerned with wealth as a measure of personal worth and more concerned about providing what they could, however little, to loved ones while it was still in their power to do so. Yet it must be kept in mind too that wealth is a relative concept. In a city like Newport, where women were as a whole poorer than men, those women who maintained their own households might not regard themselves as indigent and might still consider their possessions of worth, despite the opinions of others.

Though impoverished, Sarah Gregory would leave her eldest son "One Pound old Tenor to be Possessed by Him his heirs and assigns forEver."110 Her second son received the same inheritance as his older brother, and Sarah's youngest son would inherit "One Certain Chest of Wo[man's] Wearing Cloaths and Certain Linnens."111 Realizing her destitution, Sarah Gregory's final wish was "that all my household goods should be Sold at

\footnotetext{
109 Lebsock, Suzanne, The Free Women of Petersburg, (New York, N.Y.: W.W. Norton and Company, 1984), 134.

110 The will of Sarah Gregory, Newport Town Council Record Book, 1750-1755, Vol. 11, 53.

111 Ibid., 53.
} 
Public Vendue to Defray my Debts and funeral Charges..."112 Gloria Main's investigation of rural Massachusetts widows of the Revolutionary era reveals that, like Newport's Sarah Gregory, "[t]hose widows who did write wills had little to give on the average but what they had, they bestowed with great particularity."113 An inventory of her estate taken after her death reveals the unrefined nature of the Newport widow Sarah Albeen's life. The individual entries of her possessions were often preceded by the adjectives "old" or "coarse." She owned, among other things, "Two old Bedsteads," "Two pair old Sheets worn and patched," "One Pair coarse pillow Cases," "Two old Gowns," and "one Broken grid iron."114 Still, Albeen chose not to leave the distribution of her estate to the Town Council (as was done in cases of intestacy); rather she preferred to do so herself so as to ensure that her children received her estate "Equally Divided between Them."115 Included in her possessions were "2 spinning wheels and a foot wheel" that Sarah probably used to make and mend cloth. The spinster Sarah Chaloner must have maintained close ties with her mother, for when Sarah died in late 1760 much of her modest estate went to her mother, whom she requested administer her estate. Lee Virginia Chambers-Schiller has noted that the number of spinsters like Sarah Chaloner was on the rise in the late eighteenth century and that most of these women, such as Newport's Ann Fling, "moved between the domestic, vocational, and occupational realms according to the dint of family and economic pressure."116

\footnotetext{
112 Ibid., 53.

113 Main, Gloria L., "Widows in Rural Massachusetts on the Eve of the Revolution," Women in the Age of the American Revolution, eds. Ronald Hoffman and Peter J. Albert

(Charlottesville, Virginia: University of Virginia Press, 1989), 88.

114 The inventory of Sarah Albeen's estate, Newport Town Council Record Book, 1750-1755,

Vol. 11, 50 .

115 Ibid., 50.

116 Chambers-Schiller, Lee Virginia, Liberty, A Better Husband, (New Haven, Conn.: Yale University Press, 1984), 4.
} 
In November of 1750, Ann took her employer, the mariner William Sweet to court. According to Ann, she had been hired by Sweet "as a hired Maid Servant from the Eighteenth of October 1749 to the thirteenth day of April 1750 " during which time he neglected to pay her her wages and to reimburse her for the cash she had lent the mariner's wife at various times during her stay with the Sweets. ${ }^{117}$ Domestic service was a common source of income for colonial single women and, with over one thousand families living in the city by the late eighteenth century, likely a prevalent one in Newport. In the summer of 1759 appeared an ad in the Newport Mercury seeking "A YOUNG WOMAN, to live in a small Family. Such a Person, on Application to the Printer of this Paper, may be inform'd of a Place, which may be agreeable."118 And in November of that same year, another family sought "A SINGLE Woman, who can be well recommended, and understands Cookery..."119 One such respondent, Mary Durfy, performed a variety of paid tasks for her employer. In addition to keeping house for Gideon Freeborn, Mary also schooled his children for parts of the summers of 1751 and 1752, lent him cash, and "nett[ed]" him three pairs of gloves. ${ }^{120}$ Her work pattern was by no means unusual for women out of wedlock. Lisa Wilson writes of late eighteenth- and early nineteenth century Philadelphia widows that "[t]he low pay and fluctuating demand for marginal occupations often required a widow to take on several tasks to attain an adequate income."121 Though the nature of her work is unclear, what seems clear is that the Newport spinster Freelove Boss engaged in activities that provided her with enough compensation to reside on her own. In November of 1755 , she sued the

117 Ann Fling $v$. William Sweet, November 1755, RIICCP case file.

118 Newport Mercury, June 5, 1759.

119 Newport Mercury, November 20, 1759.

120 Mary Durfy $v$. Jonathan Freeborn, May 1755, RIICCP case file.

121 Wilson, Life After Death, 63. 
mariner John Dennis "for not performing the Promise and Assumption of him the Deft. to the Plaint. made Damage eighty pounds Currant Money of New England."122 In 1774, Freelove was one of the forty-two women in Newport that census-takers found residing completely by themselves.

In the service-oriented economy of Newport in the late $1700 \mathrm{~s}$, the work of women such as Ann Fling, Sarah Osborne, and Temperance Grant was integral not only to their own maintenance, but to the maintenance of other Newporters as well. Women were connected to the local economy in a multitude of manners. They were shopkeepers, staymakers, schoolteachers, servants, and slave holders. They were spinners. Abigail Howland was paid two pounds, fourteen shillings for eighteen skeins of worsted in 1749 . In 1757 she received twenty-two pounds, eight shillings for fifty-six skeins of cotton. ${ }^{123}$ The same editorial that lamented the poverty of many of the city's women also acknowledged that "most of them [are] very good SPINNERS."124 Newport women were midwives and wet nurses. Indeed, it was not unknown for their services to be advertised in the local paper. In 1759 , for instance, one ad announced "A WET Nurse is wanted" and in 1764 a woman advertised herself as "A wet Nurse, with a good Breast of Milk, wants a Place."125 Women were tavern keepers, boarding house owners, tailoresses, glovers, hucksters, and quilters. The widow Peckham was simply referred to as "the woman that quilts." 126 Any number of means were used to make a living. After her husband James's death, Ann Franklin took over his occupation and became editor of the Newport Mercury until her own death in April of 1763. The widow Elizabeth Gidley (whose husband John had perished in the same

\footnotetext{
122 Freelove Boss v. John Dennis, November 1755, RIICCP Record Book, Vol. E, 151.

123 George H. Richardson Scrapbook, Newport Historical Society.

124 Newport Mercury, June 5, 1769.

125 Newport Mercury, April 10, 1759; Newport Mercury, March 26, 1764.

126 George H. Richardson Scrapbook, Newport Historical Society.
} 
1744 explosion that took Temperance Grant's husband Sueton) earned at least some income by selling milk. She took the caulker Joseph Peterson to court in 1755 for his failure to pay for 207 quarts of milk he purchased from her. 127

Perhaps the most unique attempt to garner income belonged to Anne Durfey. Durfey concocted and marketed her own medical ointment under the label "Dr. Foot's Salve." In 1759, she took out an ad in the Newport Mercury to inform the city that some "pernicious" persons who "have no... connection with the said Anne Durfey" nor have "ever received the least Intimation fro[m] [her as to] how to prepare the genuine Sort" were retailing a counterfeit salve "under the same Name" as her own. Protective of her product, she reminded readers that "[t]he true and genuine Dr. Foot's Sal[ve] is made only by Anne Durfey, of Newport." According to Anne, "THE excellent Virtues" and "intrinsic Worth" of her ointment were "well known" among Newporters. Anne's claim must have had at least some validity to have inspired the impostors then "vending their spurious" imitation. Obviously rankled, she viewed their fraud as a threat, an effort "to deprive the said Durfey [of] Advantage."128 As Anne Durfey's notice suggests, the difficulties faced by colonial women in trying to maintain an independent existence could induce them to vigorously defend that which was of economic import.

In May of 1750, the widow Barsheba Loveland took her boarder Timothy Wetherel to court over the use of her garden plot. Wetherel, according to Loveland, had against her will used "near two thirds parts of said Garden Spot." ${ }^{29}$ Martha Thorp, a widow who lived alone but may have been friends

127 Elizabeth Gidley v. Joseph Peterson, May 1755, RIICCP Record Book, Vol. E, 76.

128 Newport Mercury, date destroyed.

${ }^{129}$ Barsheba Loveland v. Timothy Wetherel, May 1750, RIICCP case file. 
with Loveland, testified that she "did heare Barsheba Loveland forbid Timothy Withe[rel] upon his Perrile of Diging of any parte of her land or thatt land that he has diged up... and further that she told him thatt if he did she would sue him..."130 Elizabeth Jackson, the wife of mariner William Jackson, and Sarah Caswell, a spinster, testified for Loveland as well. Gardens were seeds of subsistence for women like Barsheba Loveland, allowing them to grow produce they otherwise would have had to purchase from others.

Jeanne Boydston has found that Martha Moore Ballard "kept a garden where she produced much of her family's food: onions, beans, corn, cabbage, and winter squash."131 By cultivating such produce, she concludes, "women enabled their households to increase their independence from the cash market."132 Similarly, Sarah Deutsch has discovered for late nineteenth century Hispanic women that "[t]he garden provided Hispanic women with an autonomous base, a source of subsistence independent of but not in competition with men."133 "Often," she contends, "a widow who had no other land survived on the produce of her garden."134 Produce could not only be cultivated for personal consumption, but for retail as well. Christine Stansell notes that the hucksters of early nineteenth century New York City frequently peddled fruits and vegetables. Ann Leighton writes of eighteenth century women that "[s]ometimes widows with green thumbs would set up shop and take orders, advertising themselves modestly."135 It was not

\footnotetext{
130 Ibid.

131 Boydston, Jeanne, Home and Work: Housework, Wages, and the Ideology of Labor in the Early Republic, (New York, N.Y.: Oxford University Press, 1990), 39-40.

132 Ibid., 40.

133 Deutsch, Sarah, No Separate Refuge: Culture, Class, and Gender on an Anglo-Hispanic Frontier in the American Southwest, 1880-1940, (New York, N.Y.: Oxford University Press, 1987), 51-52.

134 Ibid., 280.

135 Leighton, Ann, American Gardens in the Eighteenth Century, (Boston, Mass.: Houghton
} 
uncommon for merchants like Nathaniel Bird to advertise 'CHOICE GARDEN SEEDS" in the Newport Mercury. ${ }^{136}$ In colonial Newport, the garden was an economic asset.

The Newporter Edward Carr's bequest to his wife Hannah makes clear his understanding of the potential value of a garden to a widow. When he died in 1747 , he left his wife "half the house, half the dairy house, half the yard behind the house, one-half the corn, one-half the meal, one-half the other provisions laid in for the year past," yet Carr did not halve the garden. ${ }^{137}$ "[T]he garden before the door" went wholly to his widow Hannah. ${ }^{138}$ When John Dawby leased his dwelling to the widow Susannah Carr in 1753, he included the use of the garden in the fifteen pounds per quarter year rent. The premium on garden space in the compact Newport of the late 1700 s could be used by Newport women to entice prospective tenants. Looking to sell or at least lease her house in 1763, Hannah Brayton took out an advertisement in the Newport Mercury announcing her intent. The ad let those interested know that Brayton's garden was also part of the deal: "TO BE SOLD... or TO BE LETT for a term of time, by Hannah Brayton, A Large and convenient Dwelling-House, and Garden." 139 With the economy of Newport in the late eighteenth century an "undeniably... troubled one" according to Shiela Skemp, items of economic significance became even more attractive and valuable. 140

In the mid-1770s, Susannah Lamb and her friend Polly Moody were responsible for a series of thefts in Newport. Their thievery was not mere

Mifflin Company, 1976), 191.

136 Newport Mercury, April 28, 1761.

137 Clark, Bertha W., Genealogy of Carrs, 1954. NHS.

138 Ibid.

139 Newport Mercury, August 8, 1763.

140 Skemp, A Social and Cultural History of Newport, Rhode Island, 301. 
frivolous diversion however. Rather, the two women frequently "talked the Matter over before they set out together" and involved so many other women in their schemes, including Susannah's mother and Polly's sister, that their crimes were clearly an organized, purposeful effort to draw income. ${ }^{141}$ Indeed, many of the stolen items were resold to unsuspecting Newporters! The women's thievery brought them into contact with all sorts of Newporters and provides a glimpse into the daily interactions of women and men in the colonial city.

A number of different women were involved in the ring of thievery, but no men. One of the central culprits was Susannah, a spinster and daughter to the widow Mary Lamb (who was herself involved in the operation). Other members included Polly Moody and her sister Mary, also a spinster. Martha Moody, wife of the Newport housewright James Moody and seemingly a relative to Polly and Mary Moody through marriage, was also an accomplice. The connections these women had to one another, be it through blood, marriage, or friendship, facilitated the viability of the endeavor, as did the commercial nature of eighteenth century Newport with its many shops and wharves. In fact, many of the stolen goods were taken from local shops.

Susannah Lamb admitted in court that during the summer of 1775 she had entered the store of the widow Rogers and stolen "Two pairs of metal Shoe Buckles." From the shop of Mr. Bird (probably the Nathaniel Bird mentioned earlier) she took "a wood box, with some Wafers." She and Polly Moody visited Robert Bagnall's shop "with an intention of Stealing Shoes," which is exactly what they did. ${ }^{142}$ Susannah estimated that together they stole thirty pair of shoes. Tracing the subsequent path of these shoes is

${ }^{141}$ Rex v. Susannah Lamb, September 1775, R.I. Sup. Ct. Records, Newport District, Record Book F, case file.

142 Ibid. 
instructive. "[A]fter they had got the Shoes," Susannah testified, "they carried them to the Examinant's Mother [Mary Lamb]." 143 According to her daughter, the widow Lamb then sold several pair of the shoes to the shopkeeper Nat Smith. Yet in court Smith testified that "he never bought any Article of Mary Lamb..."144 Indeed, he did not. Mary Lamb herself admitted that the shoes she sold were sold not to Nat, but rather to his wife Elizabeth, who on several occasions had conducted business with the widow Lamb. For example, "[s]ome Time last Week," Elizabeth recounted on July 5, 1775, she "bought of Mary Lamb the Elder the following Articles, Six Pair of Scissors,... Nineteen Skains of coarse thread..., Twenty eight skeins finer thread..." She did admit to purchasing from Lamb on another occasion "a pair of Calamanco Shoes and gave her Five pounds Ten Shillings for them."145 Where did the money go? According to Susannah "her Mother allowed Polly Moody 4 [pounds] for every Pair of Shoes she sold, keeping the Rest of the Money the shoes sold for, for her Trouble."146

The shopkeeper Lydia Bebee informed the court after the ring was exposed that Polly Moody "came often to her Shop with Shoes lying across her Arm in open view, and said that her Uncle brought them down the River and employed her to sell them And gave her a pair out of every seven pair for her trouble."147 Polly similarly approached the wife of the shopkeeper James Drew (she was likely tending his shop) and announced that "her Uncle lived up the River, was a Shoemaker, and sent the Shoes down to her Mother to sell, and said that she had a Chest full And that many of the Shopkeepers

143 Ibid.

${ }^{144}$ Rex v. Mary Lamb, September 1775, R.I. Sup. Ct. Records, Newport District, Record Book $\mathrm{F}$, case file.

145 Ibid.

${ }^{146}$ Rex $v$. Susannah Lamb case file.

147 Ibid. 
had bought shoes."148 Polly's story was not wholly inaccurate. Though the source of the shoes is clearly false, it seems that many shopkeepers did purchase the shoes from the women, including Sarah Rumreill to whom Mary Lamb sold "Two pair."149 That Susannah, Polly, and Mary were able to hawk the stolen goods simply by approaching the storekeepers themselves suggests that women were regularly involved in a local exchange of goods and were able to find a market for goods they themselves manufactured or, in the present case, stole. This contention is further supported by following the exchange of other goods stolen by the women.

By no means were shoes the only targets of the thieves. Susannah recounted an incident in which "she was in the Shop of Mr. Paul Mumford with Polly Moody, when she stole a paper of scissors, seven pair of which she received from Polly Moody and gave them to her Mother who sold them to Nat Smith's wife for 3 [pounds]."150 Elizabeth Drew bought "a pair of scissors for Fifteen Shillings" from Polly, presumably from the same stash of scissors as those sold to Elizabeth Smith but perhaps from the one Polly and Susannah "stole from the shop of Robert and George Lawton." 151 Susannah was with Polly when Polly "stole half a paper of Pins from Miss Easton's, and that [Susannah] asked Polly Moody to step into the shop and reach her another Paper of Pins out of that Shop which she did, and the Examinant [Susannah] sold them to Nat Smith's wife for six coppers." 152 With amazing regularity items were stolen and resold. Susannah once "received from Polly Moody a Small Silver Spoon, which she cut in Two peces and sold for her." "Tobacco and Snuff," she admitted, "we sold to John Wanton The Tobacco for

\footnotetext{
148 Ibid.

149 Rex $v$. Mary Lamb case file.

${ }^{150}$ Rex $v$. Susannah Lamb case file.

151 Ibid.

152 Ibid.
} 
one shilling a Paper, and the Snuff for Thirty Shillings a Bottle." Susannah also "stole from a yard near Mr. Thurston's Meeting House, a broad Ax, which she sold to Eleazer Reed..." and "about Three Weeks ago she stole out of the yard of Robert Dunbar a small brass kettle full of Holes and patched, which she sold to Old Mr. Fryers..." The women even had the audacity to steal "a Pewter Close Stool Pan... from Governor Wanton." 153

In order to subsist, these women were willing to flout authority. Not even the Governor intimidated them. Yet that they were so frequently able to resell stolen goods to other Newporters suggests that the women were well aware of how to manipulate gender norms so as not to arouse suspicion. Not coincidentally most of the stolen articles were those that were associated with femininity... needles and pins, thread, scissors, a kettle, aprons, and pewter platters among other items. In contrast, realizing the craft of shoemaking in colonial America was the province of men, Polly understood that she had to cleverly construct an alibi designed to alleviate doubt about the source of the shoes she possessed; therefore, she claimed that her "uncle up the river" made them and she only retailed them. Though their means may have been unusual, these women were not at all unlike the Cole sisters who, though by different means, understood and exploited gender roles to maintain a living in the hustle and bustle of colonial Newport.

Independent economic existence for the women of Newport was difficult. Mary Lamb is listed in the 1774 census as a head of household and presumably had her daughter Susannah in residence. In the political and economic turmoil of the summer of 1775 , it is not unlikely that the Moodys had also fallen on hard times. In this atmosphere, items that could contribute to subsistence, whether they be slaves, gardens, or stolen property,

153 Ibid. 
were highly valued. Tellingly, several items stolen by the Lambs were not resold. Flannel clothing stolen by Susannah and Mary were "made use of about her [Mary's] GrandChild," indicating that the women had children to support. ${ }^{154}$ Similarly, in 1756, the widow Margaret Price was indicted along with Elizabeth Purcell for stealing from an open window of Isaac Polock's home "one Diaper Table Cloth" along with other practical items such as "one Holland Shirt."155 Polly Moody gave Mary Lamb one pair of the stolen shoes to wear, which Lamb admitted-"she has worn."156 Polly's sister Mary also received a pair to wear, and Martha Moody received of Mary "one pair of womans Shoes, one Quarter of a pound of thread, [and] two pair of Scissors... among other items. ${ }^{157}$ There is no evidence to suggest Martha resold these particular articles. What motivated the felonious taking and receiving of such items, then, was likely need, not greed and as such was excused by women bearing similar burdens.

The livelihoods of eighteenth century Newport women were diverse. In order to make a living, some set up shop to retail the commodities unloaded onto the city's numerous wharves; others had to steal them. Though their methods may have differed, their motives were the same... economic subsistence. The evolution of the city's economy toward commercial capitalism carried with it marital and economic risks, yet presented these women with a widened array of means to survive, whether by choice or circumstance, outside the bounds of matrimony and the legal coverture of a husband. In so doing, the transformations of Newport's economy not only altered the women's relationships to the institution of marriage, but to their

\footnotetext{
154 Rex $v$. Mary Lamb case file.

155 Rex v. Margaret Price, November 1756, Court of General Sessions Record Book, pg. 82.

156 Rex $v$. Mary Lamb case file.

157 Rex v. Martha Moody, September 1775, R.I. Sup. Ct. Records, Newport District, Record Book F, 121.
} 
colony's court system as well, for the search for subsistence could and often did drive Newport women into the local courthouse. 
Chapter Three

Navigating the Court System: The Gendered Dimension of Colonial Newport Litigation

Court records have proven in recent years to be valuable sources of data not only for historians interested in institutional history, but for social historians interested in recreating the tenor of everyday life as well. As Cornelia Hughes Dayton reminds us, "In the seventeenth and eighteenth centuries the legal system could function only with the cooperation of ordinary men and women."1 Dayton's book Women Before the Bar is one of the few full-length works on early American law that approaches New England courtrooms from the perspective of gender. Along with the work of Marylynn Salmon, Women Before the Bar documents the means by which a cultural conception of female dependency and subordination was given legalistic expression in the courtroom and the ways in which women functioned in such an environment. As a locus of social interaction, the courtroom represented an important arena in which Newport's men and women interpreted and constructed impressions of each other in the late colonial era.

In large measure, a woman's marital status dictated her relationship to the colonial Rhode Island court system. The English common law principle of unity of person as it was adopted by the American colonies effectively barred a married woman from overt, active participation in legal trials. Because she was no longer regarded as an independent agent, but rather as an extension of her husband, the law did not generally permit her to file suit on her own. Marylynn Salmon writes of the colonial wife, "At marriage, her husband

\footnotetext{
1 Dayton, Cornelia Hughes, Women Before the Bar: Gender, Law, \& Society in Connecticut, 1639-1789, (Chapel Hill, N.C.: The University of North Carolina Press, 1995), 4.
} 
gained the right and responsibility for prosecuting suits in her name as well as his own. She could not initiate a suit without him."2 Thus, in colonial court records the married woman appears (when she appears at all) in a passive role. In one of many such examples from the Newport records, though Mary Channing was the administratrix of the late Newport physician James Robinson's last will and testament, she could not prosecute Robinson's debtors without the participation of her husband John in the suit.

Significantly, this principle extended even to the prosecution of incidents occurring before the woman's marriage.

It was not unusual for the Rhode Island Inferior Court of Common Pleas, which was the court of original jurisdiction for most civil cases, to hear cases involving the recovery of debt contracted prior to a woman's marriage. Given the propensity of the area's women to generate income outside of marriage, it follows that they both incurred debts and, like Mary Durfy and Ann Fling, had individuals indebted to them. When such women married, however, their debts and credits became their husbands' debts and credits. As a result, in May of 1755 when Mallafant Sanford wanted to call in the debt owed her by Timothy Closson, a debt contracted when she was still Mallafant Linakin, she had to sue through her husband to get it. Similarly, Susannah Brownell sued George Borden through her husband John that same court session for Borden's "not performing the Promises and assumption of him the Deft. to the said Susannah when sole." ${ }^{3}$ Yet it is often difficult to establish these women's agency because, as the true beneficiaries of a favorable judgment by the court, their husbands could legally prosecute the cases themselves.

2 Salmon, Marylynn, Women and the Law of Property in Early America, (Chapel Hill, N.C.: The University of North Carolina Press, 1986), 14.

${ }_{3}$ John Brownell, et. ux. v. George Borden, RIICCP Record Book, Vol. E, 21. 
In the late summer of 1760 , Hannah Chandler, the wife of the Newport distiller Jonathan Chandler, was at home one day supervising the repair of their flooring by a pair of housecarpenters. In the midst of the project, Mary Vial, who lived in an upstairs chamber of the Chandler's house with her husband John, "came Downstairs with two Pails in her hands and went unto the well for water."4 Unfortunately for Mary, she caught the fancy of one of the carpenters, Christopher Lynsey, who "seating in a chear a smoking" declared after Mary had gone outside that "he would go to the said Mary Vial... and make friends with her and kiss her..."5 Hannah warned Lynsey that "he had better let her alone" and proceeded to the cellar, where the other carpenter "had some work... and had gone down to do it..." Cathrine Chandler, a singlewoman who likely lived in the house as well, remained upstairs to witness Mary's return from the well.

Mary the wife of the said John Vial was comeing in to said house with two Pails of water in her hands and said Lynsey meet her... and forbid her Coming in to said house and... Mary told Lynsey that she had more business there then he... had for she did not hire said house of him[.] Lynsey then Partly Pushed said Mary Down and she... catched hold on the sellar Door and Recovered herself and then she threw one of the Pails of water at... Lynsey and then she threw the Pail Likewise at said Lynsey and then... Lynsey Took the other Pail of water which stood on the steps and Threw... water all over... Mary. ${ }^{6}$

From the cellar, Hannah "did not see... Lynsey Lay any hands on... Vial's wife" yet "presently the[re] Came Down through the floor into said Cellar a Quantity of water."7 Presumably neither Hannah's husband nor Mary's husband were home at the time, for there is no mention whatsoever of their presence in the house during the assault. Despite John Vial's absence from the house and his inability to protect his wife from Lynsey's advances,

\footnotetext{
4 John Viall, et. ux. v. Christopher Lynsey, RIICCP case file, November session 1760.

${ }^{5}$ Ibid.

${ }^{6}$ Ibid.

${ }^{7}$ Ibid.
} 
however, it was he who stood to gain when Lyndsey was ordered to pay the Vials for his assault on Mary since, like any colonial husband, John "could spend her money, including wages, sell her slaves or stocks, and appropriate her clothing and jewelry."8 That the principles of coverture and unity of person could be taken advantage of by a husband to his wife's detriment is suggested by the previously-mentioned ordeal of Ann Seten.

Asa Seten left his wife Ann with "a young child to maintain without any Support or Assistance from him" only two years into their marriage. ${ }^{9}$ Forced by the situation "to apply herself to daily Labour for the maintenance of herself and her child," Ann eked out an existence. Working for others was not unknown to Ann. About six months before Asa had left her, Ann had been employed by their neighbor Zilpah Read to do some weaving for her. Finding out about the transaction, Asa "said he would have the pay for her weaving and would be Damnd before She should have any of it." 10 Though it was Zilpah who had reached the agreement with Ann, it was her husband who "Paid him [Asa] something more than half the Debt which he [Asa] Took..." Asa'a appropriation of Ann's earnings did not end here, however. Nine months after he had abandoned his wife and child, Asa "returned and making enquiry in the neighbourhood, where she had any mony due her for her work, went to the people and insisted on payment, and to obtain it took considerable less than was due and immediately absconded again and hath never returned to her since or afforded her any assistance..."11 Though clearly abusive of the right, Asa was nevertheless enabled to collect Ann's earnings by right of his marriage to her. Indeed, Ann had to plead with the

\footnotetext{
${ }^{8}$ Salmon, Women and the Law of Property in Early America, 15.

${ }^{9}$ Divorce petition of Ann Letin, March 1774, R.I. Sup. Ct. Rec., Newport District, Record Book F, 91.

10 Ibid.

11 Ibid.
} 
Rhode Island Superior Court to grant "that she may be able to keep what trifle she can earn for the support of herself [and] child..."12

Coverture was not wholly disadvantageous to the colonial wife. Just as suits prosecuted by a married woman had to go through her husband, suits initiated against the wife also had to be prosecuted through the husband. When John Freebody sought in 1750 to recover a large debt owed him by the deceased Edward Pelham, he sought out the beneficiaries of Pelham's will, his three daughters. But because all three women were married, it was their husbands, John Banister, Peter Harrison, and Joseph Cowley, who became the primary defendants. And when Freebody won the case, it was the husbands who were expected to pay. Husbands had an obligation to support and protect their wives, and should a wife violate law or custom responsibility could devolve upon the husband.

Helena Wall has uncovered several seventeenth century examples of the devolution of responsibility for wives' actions onto their husbands. For example, though Thomas Robinson made sexual advances toward William Fancy's wife in the New Haven, Connecticut of the early 1640s, Fancy failed to act on her requests that he expose Robinson's behavior. When the incidents finally came to the public's attention, Fancy was denounced "for his being as it were a pander... who should have been her protector."13 In another instance, "After convicting William Paule and Katherine Anis of 'unclean and filthy behavior' in 1657, the Plymouth court then charged Alexander Anis 'for his leaving his family, and exposing his wife to such temtations, and being as baud to her thein' and sentenced him to sit in the

\footnotetext{
12 Ibid.

13 as quoted in Wall, Helena M., Fierce Communion: Family and Community in Early America, (Cambridge, Mass.: Harvard University Press, 1990), 71.
} 
stocks while his wife and Paule were whipped."14 Though eighteenth century Newport bore little physical resemblance to and lacked the intense religiosity of these seventeenth century Puritan towns, a similar pattern of thought concerning responsibility and initiative within the institution of matrimony is discernible in the 1771 Newport case of John Pond and his wife Mary.

Both John and Mary were brought before the Superior Court in September of 1771 to answer unrelated charges of theft. In Mary's case, she had allegedly, "with Force and Arms did Steal, take and carry away out of the Dwelling House from Job Howland of Newport aforesaid mariner two pair of Silver Sugar Tongs and Six silver Tea Spoons of the value of three Pounds lawful Money..."15 Committed to the local jail while awaiting trial, Mary originally "saith she is not Guilty thereof, and for trial thereof puts herself upon the Country."16 However, soon afterward Mary withdrew her not guilty plea and admitted to the court that she was indeed guilty as charged, but that she had perpetrated the crime "by Order of John Pond... her husband."17 Her contention was surely bolstered by the fact that John was at that same time confessing his guilt in an unrelated theft of Simon Pease's warehouse. The court resolved that the responsibility for Mary's deviancy lay not with her, but rather with her husband. As such, Mary was cleared of the charge against her and released, while John was punished by having to "pay and restore to the said Job Howland three pounds lawful Mony, the specific Goods being returned as one fold, that he pay a fine of ten pounds lawful mony, And that the said John Pond... pay all costs of Prosecution [and] Conviction..."18 Recounting the episode for its readers on September 30, the Newport Mercury

\footnotetext{
14 Ibid., 71.

15 Rex v. Mary Pond, R.I. Sup. Ct. Record Book, Vol. F, 492.

16 Ibid.

17 Ibid.

18 Ibid.
} 
stated that "Mary Pond, wife of John Pond, was tried for Theft, and throwing herself upon the Mercy of the Court, her Husband was fined 10 [pounds] Lawful Money."19

By failing to report that Mary confessed to actually committing the crime, the paper's printer, Solomon Southwick, revealed too his belief that the wife bore no responsibility for her actions. Furthermore, his piece erases any hint of initiative on her part for the theft. Her role is portrayed as a passive one despite her admission of guilt. Indeed, adherence to the English precepts of coverture and unity of person led men to alienate women both legally and psychologically from a sense of agency or individual initiative. In an era when approximately ninety-five percent of women married during their lifetimes, there was a strong association in the colonial mind between women and matrimony. That association was strengthened with every article Newporters read like the story of a young English "gentlewoman" who, distraught over a failed courtship with a "Gentleman of Fortune," committed suicide by hanging herself "in her Chamber, at her Father's House in Westminster."20 Not surprisingly, then, with esteemed men like William Blackstone instructing that "The very being or legal existence of the woman is suspended during the marriage, or at least is... consolidated into that of the husband" a construction of woman as an independent actor in the public sphere was undeveloped..$^{21}$ As previously noted, it was likely this circumstance which in part blinded Benjamin Franklin to the dangers of his Newport acquaintances and Benjamin Mason to the possibility that the thief(s) he sought may have been female. Deference and humility toward

\footnotetext{
19 Newport Mercury, September 30, 1771.

20 Newport Mercury, August 1, 1763.

21 Dayton, Cornelia Hughes, Women Before the Bar: Gender, Law, \& Society in Connecticut, 1639-1789, (Chapel Hill, N.C.: The University of North Carolina Press, 1995), 19-20.
} 
men were to be part and parcel of the feminine character. Understanding this, the Newporter Sarah Osborn assured a doubter about her relation to the men who congregated at her house for spiritual guidance in the late 1760 s that "she was 'Greatly distresst' lest she move 'beyond my Line' [and]... explained... that she had 'no thing to do with' the young men who met weekly at her house, that she did not pray with tenaged boys, and that, with respect to those older men who also came regularly to her home, 'I by no means Set up for their instructor'." 22

Because marriage was so integral to the societal construction of feminine character, women existing outside of marriage - such as widows and spinsters - maintained an anomalous identity in colonial society. As women they were expected to conduct themselves in an amiable manner, or as it was put in the Newport Mercury, women were to "Learn to command Respect by your obliging, agreeable, modest, and virtuous Behavior." 23 Yet because they were not protected by a husband, the courts acknowledged that women outside of wedlock must be able to protect themselves and so granted them the ability to formulate and execute wills and contracts, buy and sell real estate on their own, as well as sue and be sued in their own names, privileges denied their married sisters and normally reserved only for men. Thus could the widow Barsheba Loveland threaten Timothy Wetherel to dig in her garden at his "Perrile" and vow that if he did she would sue him..." Women out of wedlock muddled colonial gender distinctions by their not uncommon assumption of roles associated in the colonial mind with masculinity.

\footnotetext{
22 Norton, Mary Beth, "'My Resting Reaping Times': Sarah Osborn's Defense of Her 'Unfeminine' Activities, 1767," Signs: Journal of Women in Culture and Society, Vol. 2 No. 2, (1976), 519.

23 Newport Mercury, February 28, 1763.
} 
By the mid-eighteenth century, the New England courts had become thoroughly masculinized as the region's economy evolved into what Cornelia Hughes Dayton has termed the "litigated economy." According to Dayton, the informal, largely unsophisticated local economy of seventeenth century New England afforded women in general a greater involvement in economic transactions. "Male householders whose dealings ended up in court often depended on the power of their wives and daughters to remember the details of oral agreements made months and even years before." 24 The presence of women in court, even in cases not directly involving them as litigants, was ordinary. However, as colonial trade became increasingly enmeshed in the Atlantic economy, the nature of business dealings changed. Particularly in port cities like Newport, goods were no longer exchanged through an informal barter system, but rather through an increasingly complex system of cash and credit. Notions of proper femininity, which among other things restrained their formal education, could circumscribe a woman's efficacy in the emerging economy. "As men's routine economic dealings became more commercial and cash-based," Dayton argues, "women were largely excluded from the realm of greatly expanded credit relations."25 And as New England courts grew into "a giant debt-collecting machine" in reaction to the transformations in the economy, women's presence in the courts diminished accordingly. The preponderance of economic disputes between men solidified as men's provinces both the economy and the judicial system. "The scores of men gathered in and near the courthouse during sessions facilitated male sociability and cast any women's appearance as an anomalous event."26 Just how strongly court and commerce were associated in Newporters' heads with

${ }^{24}$ Dayton, Women Before the Bar, 73.

25 Ibid., 72.

${ }^{26}$ Ibid., 101. 
men by the mid-1700s is suggested by the examples of Margaret Briggs and Alice Shearman.

When John Briggs died in early 1764, he left his wife Margaret in financial turmoil. Since he had died insolvent, John's personal property (excepting Margaret's dower) was used in accordance with the law to satisfy creditors' demands against his estate. Local government officials played a direct role in securing these claims, as town councils were required to "appoint Two or more fit Persons to be Commissioners, with full Power to receive and examine all Claims of the several Creditors, and how they are made out; which Commissioners shall put up Notifications of the Times and Places of their Meeting, to attend the Creditors, for the receiving and examining of their Claims..."27 Official designees of the council were also charged with liquidating the debtor's personal property assets through a public auction (referred to as a "vendue") in order to pay the deceased's debts. Thus in February, an ad was drawn up and submitted to the Newport Mercury announcing that "on the 19th Day of March next, at nine o'Clock in the Forenoon, at the House of the Widow Margaret Briggs, will be exposed to Sale by Public Vendue - Several sorts of Household Goods, and other personal Estate of John Briggs..."28 Margaret likely had little role in the decisions regarding the vendue and the placement of the ad. She did not affix her name to the bottom of the notice, as was routine for personal advertisers to do, and in keeping with the colonial legal custom of identifying women formally through marital status she is referred to as "the Widow." By contrast, in June of 1764 Margaret placed an ad in the Mercury herself to

\footnotetext{
27 Acts and Laws of The English Colony of Rhode Island and Providence PLantations, in New England, in America, printed by Samuel Hall (Newport, Rhode Island: 1767).

28 Newport Mercury, February 20, 1764.
} 
which she did affix her name and referred to herself not as John's widow, but rather as the administratrix of his estate and the "Subscriber" of the ad. ${ }^{29}$

Apparently, the sale of John's personal estate was not enough to satisfy all of John's creditors. Mary petitioned the colony's Superior Court in March to allow her to sell off portions of John's real estate in the hopes of satisfying the claims of "sundry persons" who still held claims against her as the administratrix of John's estate. Margaret's petition was not unusual. In 1758, the legislature required that "when the Goods and Chattels belonging to the Estate of any Person deceased shall not be sufficient to pay his just Debts,... the [Superior] Court are hereby fully empowered to authorize the Executor or Administrator of such Estate to make Sale of all or any Part of the Houses and Lands of the deceased (saving unto the Widow her Right of Dower) so far as shall be necessary to satisfy the just Debts due from the deceased."30 Indeed, the same session of court saw Patience Rogers present a similar petition. Unlike the sale of personal property, initiative with regard to the sale of real estate was left to the executor(s) or administrator(s) of the estate. Therefore, when Margaret Briggs presented the June ad to the Newport Mercury offering to sell "all the Real Estate (or Two, Thirds thereof) that belonged to John Briggs... to the Highest Bidder" herself, she found herself enmeshed in practices commonly linked to the masculine character, not the feminine one. When women married, as they were expected to do, they lost all rights to real estate and the sale thereof. Real estate transactions, then, were the province of men. Thus did the printer, when setting Margaret's ad to print, erroneously refer to Margaret as a male. "NOTICE is hereby given," read the initial ad, "that there is to be sold by the

${ }^{29}$ Newport Mercury, June 25, 1764.

${ }^{30}$ Acts and Laws of the English Colony of Rhode Island. 
Subscriber [Margaret], at the House where he now lives..."31 (Catching the mistake, the newspaper reprinted the ad correctly the following week.) Were this a unique event, one could dismiss it as a mistake devoid of any real meaning for assessing gender relations in colonial Newport... but it was not unique.

By law, any case brought before the colony's courts was to be transcribed by a clerk into a court record book, a tedious job indeed considering that by the mid-1700s the Court of Common Pleas in Newport, for example, handled roughly 1,000 cases each year. When the Court of Common Pleas met in Newport in May of 1760, the widow Alice Shearman of nearby Portsmouth brought an action of trover against George Shearman. Despite seeking two hundred pounds in damages, Alice dropped the suit and was ordered to pay George the cost of the suit. Perhaps out of habit, since female litigants appeared in only approximately ten percent of that court's cases, did the clerk in 1760 mistakenly record that Alice "discontinued his suit."32 Nevertheless, the mistake clearly illustrates the extent to which, even psychologically, the court system had become masculinized and women's presence there rendered an anomaly.

Not coincidentally, both cases of mistaken gender identity involved widows. As previously mentioned, their position in colonial society was ambiguous, and more than other women widows complicated gender norms and distinctions. Released from the bonds of matrimony, the widow was released from that institution which defined femininity. As a feme sole, it was overwhelmingly the widowed woman who, whether by choice or

32 Alice Shearman v. George Shearman, RIICCP Record Book, Vol. F, 311. 
circumstance, was most frequently immersed in masculine spheres of colonial activity, particularly the courts.

Very often widows appeared in the colony's courts as executrixes or administratrixes of their deceased husbands' estates. The function entailed much responsibility, subjecting women to the rigors of the colonial financial and legal systems. As accountability for the deceased's debts and credits devolved upon the executor or administrator, the role increased the likelihood of confrontation with men. It is unlikely, for instance, that Sarah Shaw had much familiarity with Abiel Cook while her husband Lemuel was alive. Before his death, Lemuel contracted numerous debts through promissory notes - no less than twenty-five between 1753 and 1754 - to a multitude of persons. To Abiel, he pledged the "some of one hundred and sixetey five pound olde tennor for a black horse." 33 But when Lemuel passed away, it was Sarah who became liable for Lemuel's debts as administratrix of his estate. And Cook went after her. Though she maintained that she had nothing left to give him, Cook insisted to the Court of Common Pleas that she "hath other Goods and Chattles of the Estate" which could be used to satisfy his claim. ${ }^{34}$ Finding out otherwise, he dropped the suit.

Though administering an estate was rarely financially rewarding and often full of trial and tribulation, widows were generally desirous of the role. Frequent were the appeals of widows to the town council requesting administration of their husbands' estates. As was required of potential administrators by law, Rachael Dehane on September 6, 1751 "appeared in Council and prayed that She might have Administration Granted Her on... Husband's personall Estates and She having Given Bond for Her Faithfully

33 Abiel Cook v. Lemuel Shaw, November 1753, RIICCP case file.

${ }^{34}$ Abiel Cook v. Sarah Shaw, November 1755, RIICCP case file. 
Performing..."35 Though some women, like Alexander McDonald's widow, refused to administer their husbands' estates, the town council almost unequivocally granted administration to those women who sought it. Why the town council did so is unclear, but William Ricketson's findings for Massachusetts Bay in this regard are suggestive.

In his examination of the relationship during King Philip's War between widows and the Massachusetts Bay colony courts, Ricketson discovered that the volume of widows appearing before the courts affected the dispensation of estates. Though the casualties from King Philip's War are difficult to calculate, most historians agree they numbered in the thousands. As many men left behind wives, "[t]he rapid creation of scores of bereaved women who were younger than normal, whose husbands were more likely to have died intestate, and who were left with relatively small estates made it necessary to adopt new means of dealing with widows. ${ }^{36}$ Given the swift enlargement of court business occasioned by the war and the "sudden appearance of so many indigent widows, most of them with minor children," the courts were more liberal in according widows entrustment of their husbands' property, Ricketson argues, than even the husbands themselves would have been. ${ }^{37}$ As by the late colonial era the Newport Town Council found its daily business increasingly variegated and complicated by an expanded population base, as more and more of the city's men were exposed to the hazards of the seas, and as the colony found itself embroiled in the French and Indian War (Sydney James estimates that "Rhode Island supplied in the early war years almost a

\footnotetext{
35 Newport Town Council Meeting Notes, September 6, 1751, Newport Town Council Record Book, Volume 11 (1750-1755).

36 Ricketson, William F., "To Be Young, Poor, and Alone: The Experience of Widowhood in the Massachusetts Bay Colony, 1675-1676," The New England Quarterly 64 (March 1991), 114.

37 Ibid., 118.
} 
tenth of its males of military age"38), it is likely that the Town Council too became more liberal regarding the dispensation of administration rights on estates. Despite the headaches often accompanying the role of administratrix, women generally wanted the responsibility. The evidence suggests that both men and women viewed the positions of executor and administrator as positions of trust.

One might imagine the anger and grief the shipcarpenter Francis Bissell must have felt upon returning to Newport to find his wife Penelope with a daughter "Got in my Absence... by Kendell Nichols of Newport aforesaid bricklayer."39 In fact, so disturbed was he that he mentioned the episode in his last will and provided Abigail (the child of the adulterous act) a paltry "sum of five shillings" as a bequest. Having broken her husband's trust, Penelope was given by him only the bare minimum of a dower, one-third of the household goods and the use of the best room in his houses, but only for so long as she remained a widow. By contrast, the same Town Council meeting proved the will of Humphrey Walters, who left his "Well Beloved Wife Elizabeth Walters all my Estate of what Nature or kind Soever and whereforever the same May be found to be Enjoyed by her, her Heirs and assigns forEver."40 Walters requested that his wife be appointed his executrix; Bissell refused to allow his wife this office of trust and instead nominated William Cranston. Penelope likely understood the meaning behind her husband's slight and, as colonial women often viewed widowhood as "an office of trusteeship and stewardship," felt the sting of his loss of faith

\footnotetext{
38 James, Sydney V., Colonial Rhode Island - A History, (New York, N.Y.: Charles Scribner's Sons, 1975), 285.

39 The will of Francis Bissell, Newport Town Council Record Book, Volume 11 (1750-1755), pg. 56.

40 The will of Humphrey Walters, Newport Town Council Record Book, Volume 11 (17501755), pg. 55.
} 
in her one last time. ${ }^{41}$ The women who approached the Council praying they be granted administration of intestate estates, then, may well have felt not only an obligation to administer but also a sense that they were competent enough to be trusted with the estates.

Mary Ward certainly felt Isabel Marchant capable of executing her will, and requested that Marchant do so. As Ward's executrix, Marchant in the spring of 1769 forced payment of a debt owed the estate by William Cranston. Incidentally, representing Isabel in this case and others was her step-son, the esteemed Newport lawyer Henry Marchant, whom as a youth had been "educated by his step-mother, aided by the liberality of Henry Collins." 42 After the death of Isabel's husband Huxford, she and Collins had battled over the terms of his will, with Isabel asserting her right as his wife to her proper dower. "Because the common law denied femes coverts the right to own property, it had a strong moral obligation to provide support during widowhood..." 43 What may have been at issue in this case, however, was the nature of Isabel's support. As the executor of Huxford's will, Collins argued that since the will's named wife, Sarah, died before Huxford (probably in childbirth or shortly thereafter, since in that 1743 will Huxford refers to her as "now bigg with [child]") her widow's portion did not apply to Isabel and thus should go to Huxford's children. Collins may have expected the children to assume responsibility for Isabel's welfare. Several historians have noted a preference among men of means in the late colonial era, men like Henry Collins, to grant children (particularly sons) greater control over property and leave widows more dependent on good will for support than on dower rights. Carole Shammas has observed:

\footnotetext{
41 Dayton, Women Before the Bar, 76.

42 Index File, Newport Historical Society..

${ }^{43}$ Salmon, Women and the Law of Property in Early America, 142.
} 
The richer a husband was, the less likely he was to leave his wife more or even the same share as intestacy statutes provided.... They required that whoever receive the homestead, usually an elder son, furnish the widow with food, firewood, and room space.... Widowhood frequently meant becoming a lodger in your own household. ${ }^{44}$

Isabel was of a different mind. She argued that her husband died intestate, since no will named her as his wife, and as such she was entitled to her dower right of one-third his personal estate. Perhaps observing or hearing of instances in which dependent mothers were mistreated by offspring, Isabel may understandably have been wary of making her welfare contingent on that of others. Indeed, only five years after Isabel's dispute with Collins went to court, the Rhode Island General Assembly passed an enactment entitled "An ACT declaring how far Parents and Children are liable to maintain each other." Clearly, maintenance of mothers was not always achieved willingly.

In 1750 the widow Elizabeth Coggeshall brought suit against her daughter Elizabeth in order to recover her dower. The court awarded her the one-third of the house and stable she requested. Newporter Sarah Dunbarr was forced to sue the executor of her husband's will, John Usher, to receive her legacy from George. The death of her husband Benjamin Brenton drew Alice Brenton into court when John Nichols neglected to present the widow "her Reasonable Dower which to her belongs of one... Dwelling House [and] Lot of Land... of which she hath nothing as she saith Damage Six Thousand Pounds Current Money of New England."45 Likewise, Wait Easton took to court Nicholas Easton in order that "he the Deft. justly and without Delay render to the Plaint. who was late the wife of... James Easton her seasonable Dower

\footnotetext{
44 Shamman, Carole, "Eariy American Women and Control over Capital,". Women in the Age of the American Revolution, eds. Ronald Hoffman and Peter J. Albert (Charlottesville, Va.: University Press of Virginia, 1989), 143-147.

${ }^{45}$ Alice Brenton v. John Nichols, RIICCP Record Book, Vol. F.
} 
of a certain... Dwelling House[,] Barn[,] Cheese House[,] and about eighty five Acres of Land being part Meadow part Pasture and part Arable Land..."46 Yet it was not only widowed women who found their way into court over inheritance and other disputes. Then as now, a variety of disputes, frequently involving monetary affairs, could place loved ones at odds, and it was not unknown for in-laws, siblings, and even parents and children to prosecute one another. Colonial America was a litigious society and "[m] ost householders at some point in their lifetime could expect to be threatened by a creditor with a lawsuit, see a cow led away in attachment for an unpaid debt, or be forced themselves to sue a debtor whom they feared was about to leave the country." 47

The spinster Mary Rodman prosecuted her younger brother Thomas as the administrator of their father's estate. In his will, Mary's father had stipulated that she was to have of his estate one thousand pounds old tenor "to be paid her by my Executor at the age of Twenty one Years or day of Marriage which shall first Happens..." Mary insisted that her brother "hath in his Hands sufficient of the Goods and Chattels of the said Clarke Rodman, to satisfy and pay the Plaintiff who is arrived at the age of Twenty one Years, the aforesaid Legacy." 48 As Mary was single, and would remain so the rest of her life, her father's legacy was of the utmost financial importance to her and she was willing to take her brother to court in order to receive it. (Interestingly, the shopkeeper Sarah Rumreil took Thomas to court the same session to recover the value of goods she had given his late father on credit but for which she never received payment.)

\footnotetext{
46 Wait Easton v. Nicholas Easton, RIICCP Record Book, Vol. F., 393.

47 Dayton, Women Before the Bar, 70.

48 Mary Rodman v. Thomas Rodman, May 1755, RIICCP case file.
} 
In 1751, Joseph Cooke agreed to make repairs on that part of the Long Wharf owned by his mother Susannah and did so again in 1753 . When Joseph sued his mother in 1755 to collect the money owed for his repairs to her part of the wharf, she countersued to recover the value of two loans her son had long failed to repay. Susannah likely came by her share of the Long Wharf through widowhood and seems to have been living a comfortable existence in the $1750 \mathrm{~s}$. A testament to the city's growing prosperity and trade networking, the Long Wharf was symbolic of all that Newport had become in the eighteenth century. Organized as the Long Wharf proprietors, the city's leading merchants sought to facilitate larger vessels entering the harbor, and so had designed a dock that would extend further into Newport Harbor than any previous wharf. "In addition to their practical motives, the Long Wharf proprietors saw their project as part of an effort to give Newport the status of a major seaport."49 The wharf, then, was laden with symbolism and attests to the power of economic interests to shape and mold the city's image. As such, it is particularly significant that several women at various times after the wharf's construction owned portions of that prized dock.

When the proprietors of the Long Wharf approached the General Assembly in 1769 requesting a lottery to defray the costs of expanding the wharf an additional 170 feet beyond its current distance, three women - Mrs. Turner, Mrs. Mary Carr, and Mary Rodman - appeared on the petition as proprietors. ${ }^{50}$ The presence of these women in such a prominent commercial rank as Long Wharf proprietor problematized gendered notions of trade and business, inverting the paradigm of male economic control and dominance over women.

\footnotetext{
49 Withey, Lynne, Urban Growth in Colonial Rhode Island, (Albany, N.Y.: State University of New York Press, 1984), 30.

50 Colonial Records of Rhode Island, 577.
} 
When the shopkeeper John Miller sought in 1766 to let half of his "large Store on the Long Wharf," he directed prospective lessees to negotiate not with him, but rather to "Enquire of Mary Rodman, at the Point."51 The prosperity of the seaport allowed some women to exert economic influence over Newport's development. Cornelia Hughes Dayton writes of such women that "the court records provide indirect evidence that well-propertied widows in the most expansive decades of New England's preindustrial history played a role similar to that of wealthy widows in commercializing regions of early modern England: they were an important source of both consumer and commercial loans and therefore, it must be acknowledged, played a modest but significant part in the capitalization and commercial development of the countryside." 52

Newport women not infrequently came into court to recover the value of loans furnished by them to the city's men. As mentioned, the singlewoman Mary Durfy sued her employer for the recovery of money she had lent to him. Mary Briggs was probably sorry that in the early 1750 s she, like so many others, had loaned hundreds of pounds to Lemuel Shaw only to see him go to debtor's prison for his inability to repay the loans. On March 7, 1755 William Palmer promised in writing that he would "pay to Temperance Grant on Order, Fifty pounds Old Tenor with Interest after expiration of said time till paid for Value received 50 [pounds]." Having asked Palmer for payment several times without satisfaction, Grant took Palmer to court. Cornelia Hughes Dayton recognizes such lending among colonial women as a method of generating income rather than simple kindness. "After [around 1715], the growing popularity of promissory notes gave widows greater chances to earn

51 Newport Mercury, March 17, 1766.

52 Dayton, Women Before the Bar, 94. 
interest as frequent, small lenders."53 And for others it provided an opportunity to keep their heads above water financially, if only temporarily.

Just how active widow networks could be in credit/debt activities is suggested by the disparate lawsuits of Temperance Grant, Rachel Greene, and Ann Maylem. On February 29, 1752 Ann Maylem and Temperance Grant agreed to terms on a loan in which Maylem "promise[d] to pay Mrs. Temperance Grant on Order Sixty five pounds... on demand for Value received."54 Two years later, Grant sued the widow Maylem for failure to repay the loan. Several years later, Rachel Greene, a widow and a consort of Maylem's, lent several hundred pounds to the widow Mary Cowley upon Mary's pledge "to pay to Sarah Greene Widow on Order the Sum of Six hundred and forty pounds old Tenor in one month from the Date hereof and if not paid then Interest according to Custom till paid for Value received."55 Cowley was an economically active woman, who in 1764 ran a dancing school and in 1773 opened up the Crown Coffee in her home. In 1775 she was one of only thirty-four women to appear on the city's tax list, but in 1764 she proved unable to pay off the loan from Greene and was promptly sued. When Rachel Greene later died, it was Ann Maylem who would appear before the Town Council requesting administration of the estate and responsibility to prosecute Greene's debtors. The evidence suggests that such networks were likely common. ${ }^{56}$

\footnotetext{
${ }^{53}$ Dayton, Women Before the Bar, 87.

54 Temperance Grant $v$. Ann Maylem, May 1754, RIICCP case file.

55 Sarah Greene v. Mary Cowley, September 1764, RIICCP case file.

56 Beyond court data, the records indicate that many women in colonial cities worked and lived in close quarters. In A Dependent People, Elaine Forman Crane notes this tendency of Newport women. Moreover, of Philadelphia women in 1775, Carole Shammas has found that women out of wedlock were more likely to board in the homes of other women. In Newport, some women chose to keep school at the homes of local widows. It was also not unknown for women like Ann Rathbun and Margaret Mitchell to set up business together. Interestingly, as was standard for men's jointly-run enterprises, when the two women together sued Joshua Bills in 1753 for sundry expenses owed their boardinghouse, their partnership was described by the court as a "company."
} 
So adventurous were some women financially that they actively lent the General Assembly money on interest. In 1757, Sarah Wright complained along with several male lenders that

... we have lent the Government sundry Sums of Money when the Colony was under great Necessity of the same And have taken the General Treasury's Bonds therefor, most of which are now Due but we can get neither Principal nor Interest which we think is a very great Hardship more especially as the Money has sunk very much since we parted with it \& continues to do so... Therefore we humbly pray your Honrs. to direct the Genl. Treasurer (since it is not in his Power to pay us) to settle \& state the Money as it was when we lent it \& renew our Bonds with the Money so fix'd and upon those Conditions we are willing to take up...57

Similarly, Isabel Marchant petitioned the Assembly in 1777 in regard to her loan to the government,

... that some time since she lent the general treasurer a sum of money, to supply the necessities of government upon a very pressing occasion; and that she hath now an opportunity of making use of the same, to her advantage; and thereupon prayed this Assembly, that the general treasurer might be directed to pay her the said sum, by her lent, with the interest due thereon..$^{58}$

The two women's requests for the interest due them make clear that they regarded their loans to the treasurer as investments and themselves as investors, as does Marchant's disclosure that she could better use the capital in question "to her advantage" elsewhere. Elaine Forman Crane has discovered the names of several women among the Newport real estate investors of lots located in Woodstock, Connecticut in the 1760 s. Such women were certainly not of the same character as the seventeenth century Rhode Island women Lyle Koehler has described as essentially inert in the public economic realm. Rather, they more closely resemble the New York women who fired off a public letter to a local newspaper in 1773 "demanding their

57 Petition of Joseph Jacobs and others before the Rhode Island General Assembly, January $25,1757$.

${ }^{58}$ Colonial Records of Rhode Island, 312. 
rights as property-owners and citizens."59 Their economic leverage and outof-wedlock legal status afforded such women identities unavailable to their wedded sisters. Cornelia Hughes Dayton has observed that in the late colonial era more women were entering the Connecticut courts to pursue their own debts than were pursuing them for others as administratrixes and executrixes. Moreover, when they did enter the court system in this period they overwhelmingly entered as the litigant of initiative, the plaintiff, rather than as the defendant. ${ }^{60}$ Likewise, women in this era were approximately twice as apt to enter the Newport Court of Common Pleas as plaintiffs than as defendants. Dayton suggests that such a pattern "indicates that most widows continued to actively avoid coming into court as debtors and that wealthy widows engaged in frequent lending, but not borrowing."61 Yet in the stagnating and uncertain economy of the Revolutionary era, both the Rhode Island General Assembly and the colony's court system were saddled with a number of men and women whose fortunes were washed away.

Though Caleb Gardner had hoped the proceeds of the family shop would sustain his family after his death, his son appeared before the General Assembly in June of 1770 decrying the excessive competition of the Newport economy and petitioning for relief as an insolvent debtor. An act passed by the Assembly in 1756 protected an insolvent debtor from imprisonment if the debtor agreed to "deliver and assign all his property (reasonable and necessary bedding and wearing apparel for himself and family excepted) to three court-appointed commissioners who, in turn, were to distribute the

59 Matthaei, Julie A., An Economic History of Women in America: Women's Work, the Sexual Division of Labor, and the Development of Capitalism, (New York, N.Y.: Schocken Books, 1982), 67.

60 see Dayton, Women Before the Bar, pages 99-100.

61 Ibid., 101. 
proceeds among the creditors on a proportional basis."62 Peter J. Coleman notes that with his petition granted, Gardner was able to make a "fresh start" and was soon prospering again. Instead of languishing in prison, which "pushed many a debtor into a more or less permanent state of pauperism," Gardner was plugged back into the economy by the act. As the case of the innholder Mary Pinnegar suggests, the 1756 act potentially benefited businesswomen as well as businessmen.

In an era when marriage was expected of women and the overwhelming majority entered wedlock, Mary Pinnegar remained single her entire life. To support herself, the Newport spinster operated an inn and her business became another cog in the machine of the local economy. Just as she provided services to others, they provided services to her. The local brewer Giles Hosier stocked her with barrels of "Strong Beer" to dispense to customers. Pinnegar's purchase of a single barrel netted Hosier twenty-one pounds. From the retailer Nathaniel Bird, Mary purchased such items as cards, plates, knives and forks, and bottles of mustard which she employed in her occupation. In 1765 Mary announced the opening of her coffee house in the Newport Mercury, but four years later she declared herself insolvent "through many Losses sustained in the Course of her Business" and sought the clemency of the 1756 act. ${ }^{63}$ Though much of her estate would probably be lost (including that which she used to operate the inn - "1 Scales \& Weights," "5 Tables," "14 Chairs," "2 Backgammon Tables," "1 Sign \& Retailing Board," "1 Frying-pan," "3 Funnels," "1 Note of Hand for 100 [pounds] old Tenor," and "Book containing Sundry Accounts unsettled") she would avoid debtors' prison and, like Caleb Gardner, gain a second chance. That she subsequently

62 Coleman, Peter J., "The Insolvent Debtor in Rhode Island," The William and Mary Quarterly 3rd Series, Vol. XXII (July 1965).

63 The Insolvency Petition of Mary Pinnegar, November 1769, R.I. Superior Court case file. 
prospered is evidenced by the fact that in $\mathbf{1 7 7 2}$ the town assessed her a tax of seven shillings, rather high for a colonial woman who only three years earlier had declared bankruptcy. Other women, however, were not so lucky.

When her husband Henry passed away, Mary Taggart became burdened with his outstanding debts as co-executor of his estate. Soon she was involved in protracted legal disputes with her husband's creditors and debtors, men like the merchant William Mumford and the ship captain John Downer (who incidentally would leave his own wife Sarah widowed only two years later when killed during an engagement with a French Privateer in 1762). Left with "an ancient Mother that is Bed-ridden and hath been so for many Years whom [Mary] constantly attended," Mary proved unable to make ends meet and in 1765 found herself "confined in His Majesty's Gaol in Newport" for failure to discharge a debt "for a large Sum of Money" that "she is not able to pay." With little to offer her creditors beyond such worn items as "1 Old Bonnet," "2 Old Quilted Petticoats," "4 Old Handkerchiefs," and "1 pr. Old Shoes," Mary Taggart petitioned for relief under the colony's 1756 act. Though her petition was granted, Mary probably never prospered to the degree of Mary Pinnegar. Rather, she likely went the way of Elizabeth Hunt.

When Elizabeth's husband, the mariner George Hunt, died in 1759 he left his wife "a Widow with four small children." Elizabeth was able to pay off George's debts and she herself "hath since received about three thousand two hundred pounds old Tenor for house rent" which she had "used with the utmost Frugality" to support herself and her children. Indeed, in the spring of 1765 she advertised to let part of her "genteel House, on the Hill, near the Library with many Conveniences, and very commodious for a small Family."64 Yet it was not enough. In 1767 she informed the colony's Superior

64 Newport Mercury, April 29, 1765. 
Court that "she is at this Time indebted about fourteen hundred or fifteen hundred pounds old Tenor sundry persons, who are uneasy and threaten to sue her unless she pays her respective dues to perform[,] which she is unable..." Elizabeth asked that the court allow her to sell a piece of her late husband's real estate "that she may be thereby enabled to pay her Creditors."

By 1767, all Newporters had good reason to be uneasy. The city's involvement in the French and Indian War had been less than pleasant. Taxes were raised, "[s]everal major mercantile firms sank hopelessly into debt as a result of losses at sea," and the British government under Lord Grenville had begun to tighten control over colonial commerce. Indeed, just as the contest with the French was ending, others were beginning. Clashes with the British in Newport Harbor were arising with regularity and the city was earning the ire of colonial neighbors by refusing to subscribe to nonimportation agreements during 1765 and 1766 despite their displeasure with the newly-passed Stamp Act. Worried about their financial security in this uneasy environment, the merchants turned to the courts in increasing numbers. Like Cornelia Hughes Dayton's Connecticut, Rhode Island's courts were becoming a giant debt-collecting machine, creating a close association in Newporters' minds between the court and the failing economy. Lynne Withey has noted that the proportion of merchants appearing before the Court of Common Pleas as litigants increased from 35 percent in 1750 to 49 percent by 1770.65 The women who most often appeared in court to combat the city's men were not legally innocuous wives, but rather widows and single women whose existence out of wedlock fortified them with the legal authority to challenge the economic livelihoods of men. And these women had found their way into almost every little nook and cranny of the local economy, from

65 see Withey, Urban Growth in Colonial Rhode Island, 143. 
huckstering fruits and vegetables and running inns and shops to owning parts of the greatest wharf in Newport and even holding real estate investments and government securities.

As much as they could given the dominance of the city's men in this arena, the women had also inched their way into overseas commercial trade. Shiela Skemp has discovered that "Sally Duncan, sister of Captain James Duncan, often put a barrel or two of molasses aboard one of her brother's vessels in hopes of making a tidy little profit."66 The widow Sarah Sparks took the merchant Isaac Elizer and the firm of Naphtali Hart and Company to court over two bills of exchange the London merchant Joseph Sherwood had entrusted them to deliver to her upon return to Newport. Because bills of exchange functioned like checks, it is likely Sparks had provided some commodity to Sherwood through the Newport merchants for which he was compensating her. The 1767 bills instructed Elizer and Hart to "Pay to Sarah Sparks of Newport Rhode Island on her Order" the sum of twenty-four pounds and thirty-five pounds respectively as the go-betweens for the widow and the Englishman. Neither merchant complied, so in May of the following year Sparks sued both. Incidentally, four years later Naphtali Hart and Company would declare insolvency.

At the same time that Newport's economy was being buffeted by the economic dislocations that would ruin Hart, Gloria Main has found that "[c]ompared to earlier years, almost three times as many girls and young unmarried women appear on the record as working for someone other than their parents in the closing decades of the colonial period."67 With the number of women in Newport beginning to outstrip that of men and more

66 Skemp, A Social and Cultural History of Newport, Rhode Island, 366.

67 Main, Gloria L., "Gender, Work, and Wages in Colonial America," The William and Mary Quarterly, 3rd Series, Vol. LI (January 1994), 51. 
and more of these women subsisting without a husband at the hearth (becoming increasingly visible in the public economic domain and the courts as economic threats rather than domestic helpmeets), an anxiety about the institution of marriage developed. As Newport increasingly felt the political and economic instability of the Revolutionary era, a discourse grounded in republican rhetoric developed in the seaport to address the character of marriage. Rather than dismiss the inherited construction of a femininity based on the dependency and domesticity of marriage as incongruent with the situation in which a growing number of the city's women found themselves, concerned community members instead celebrated the traditional notion of matrimony as the pinnacle of femininity and social stability. Ironically, at a time when change was in the air and the very notion of tradition was being questioned by Rhode Islanders (who would make their colony an early and forceful proponent for independence from Great Britain), Newport's civic leaders promoted tradition for the city's women. 


\section{Chapter Four}

The Tides of War: Fortifying the City with Wedded Bliss

Clashing over their findings, historians seeking to assess the impact of the American Revolution on colonial women have correspondingly constructed divergent explanations respecting that colossal event's significance for participants and posterity alike. One school of thought posits the theory that both the physical and psychological components of the Revolutionary experience transformed women's self-conceptions in American society. Buoyed by a self-assertiveness brought on by the exigencies of war and by a rhetoric that preached virtue and independence, women helped reformulate their function in the early republic to include positive public responsibilities that reflected a new-found self-confidence. "In the chaos of the revolutionary period," Mary Beth Norton writes, "[women] accordingly began the process of developing an innovative conception of their relationship to the public realm." 1 The Revolution, according to this interpretation, was a source of female empowerment. Though the impetus for change was clearly the tumult of the times, historians like Norton accord women primary agency in what they perceive as a positive redefinition of the feminine role in the nascent United States. As Linda Kerber puts it, "If American women were to count themselves as the daughters of Liberty, they would have to invent their own ideology." 2 The onset of revolution, then, marked a break with the past for women. "As the nature of American government and society had changed

\footnotetext{
${ }^{1}$ Norton, Mary Beth, Liberty's Daughters, (Boston, Mass.: Little, Brown, and Company, 1980), 170.

2 Kerber, Linda, Women of the Republic, (Chapel Hill, N.C.: University of North Carolina Press, 1980), 32.
} 
during the half-century that witnessed the Revolution, so too had American notions of womanhood."3

A competing school of thought, led by the work of Joan Hoff Wilson, disputes the "revolutionary" impact of the Revolution on colonial women. Wilson contends that neither the public rights nor the private conception of women were significantly altered by the Revolutionary experience. The advent of Republican Motherhood, a concept hailed by Norton and Kerber as reflective of a new public image of women in the post-Revolutionary period, represented instead, Wilson argues, the perpetuation of pre-Revolutionary gender distinctions. Women were given the role of keepers of the virtue at the very time the efficacy of public virtue was being questioned and abandoned by their husbands, brothers, and sons. Thus the virtue women were charged with was a private virtue. "After virtue became a female attribute in the 1780 s and 1790 s, it remained private and 'outside politics,' thus effectively excluding women from 'institutionalized public life'."4 Rather than heralding a new era for American women, the Revolution more firmly entrenched them in their established role in the private sphere of subservient wife and mother. These women, Wilson insists, "simply could not conceive of a society the standards of which were not set by males." ${ }^{\text {5 }}$

Though the present study of Newport's female population does not extend into the post-Revolutionary period, there is evidence to indicate a preRevolutionary antecedent to the processes Wilson finds at work in the early Republic. As the seaport hurtled toward revolution, an effort was made, from a myriad of motives, to remind the city's female inhabitants that the

\footnotetext{
3 Norton, Liberty's Daughters, 296.

${ }^{4}$ Hoff, Joan, Law, Gender, and Injustice, (New York, N.Y.: New York University Press, 1991), 57.

5 Ibid., 57.
} 
preferred station for them was as wife. Somewhat paradoxically, as Newport's men worked to free themselves from their traditional relationship to mother England, they simultaneously sought to edify their women as to the virtues of wedlock and the traditional feminine calling of wifehood.

Tremendous anxiety and instability characterized Newport in the years following the cessation of the French and Indian War. The ending of that war, which Sheila Skemp notes had kept Newporters hard at work, sent the local economy into a funk from which it would never really emerge. Post-war Imperial policies aimed at corralling colonial economic and political autonomy disrupted the entire Newport community. As the British authorities increasingly made their presence felt, Newport grew factious. In a local culture that placed a premium on affluence and economic achievement, British meddling threatened more than the loss of profits, it menaced Newporters' very identities.

When British authorities decided following the French and Indian War that depleted war coffers ought to be replenished by those for whom they were opened, their collection plan struck at the pillar upon which eighteenth century Newport had been built - overseas commercial trade. Not surprisingly, then, when news reached Newport of the British scheme to raise revenue via a vigorously-enforced tax on foreign molasses (a staple of the seaport's trade) Newporters felt threatened. Some local merchants echoed in thought and others in deed what the Malbones expressed in writing: "It is certainly unnatural for us to Suppose that [the Ministry] have premeditatingly [laid] these schemes to effect our Ruin... but... in general we do think so..."6 Presaging greater acts of rebellion by townspeople, a group of

\footnotetext{
6 as qouted in Crane, Elaine Forman, A Dependent People: Newport, Rhode Island in the Revolutionary Era, (New York, N.Y.: Fordham Un .iversity Press, 1991), 111.
} 
Newporters manifested their unhappiness with the Sugar Act by illegally "reappropriating" confiscated molasses from royal authorities. The next decade in Newport would be marked by ever-increasing dissension as townspeople struggled over their personal and collective futures in the seaport.

By no means were city residents united over the proper response to British initiatives. In fact, there were active elements of loyalism within the seaport that rankled outsiders as much as fellow residents. Characteristic of their community, these Newporters had constructed their identities out of economic interest. The steady growth in prosperity had led some Newporters to embrace English gentry culture in the search for status, a pattern James Deetz and T.H. Breen have found so pervaded eighteenth century America that "on the eve of the American Revolution, Americans were more English than they had been in the past since the first years of the colonies."7 "The greater incidence of Toryism among Newport's elite," Lynne Withey argues, "can be attributed, in part, to the presence of more men with direct ties to England - either by birth or patronage - and the greater influence of the Church of England there."8 The influence of the Anglican Church in Newport, as Elaine Forman Crane has noted, was itself directly related to the city's growing affluence and the desire for status. She confirms that "the most visible and consistent advocates of the British regulations were Anglicans."9 Just as economic interest had led them to the Anglican faith, so too did economic interest shape their stand on the Revolutionary upheaval around them. "The majority of Newport Loyalists," Joel Cohen has

\footnotetext{
7 as quoted in Breen, T.H., "An Empire of Goods: The Anglicanization of Colonial America, 1690-1776," Colonial America, fourth edition, ed. by Stanley Katz, John Murrin, and Douglas Greenberg, (New Yirk, N.Y.: Mcgraw-Hill, Inc., 1993), 396.

${ }^{8}$ Withey, Lynne, Urban Growth in Colonial Rhode Island, (Albany, N.Y.: State University of New York Press, 1984), 79.

${ }^{9}$ Crane, A Dependent People, 129.
} 
discovered, "were conservative merchants who were more fearful of armed rebellion and its attendant destruction of trade and constitutional authority than they were of Parliament's encroachments."10 These men earned the ire of many as tension with Britain increased, including James Otis of Boston who labeled them a "little, dirty, drinking, drabbing, contaminated knot of thieves, beggars, and transports..."11 Yet while the loyalism of some Newporters was infused with economic self-interest, the patriotism of others was equally tempered by such motives.

Despite the residents' anger in 1764 and 1765 over both the Revenue Act and the Stamp Act (against which they rioted), the city's merchants refused to participate in what patriots understood to be a valuable foil against royal encroachments, non-importation agreements. Despite the political advantage afforded economic boycotts, in Newport the economic price was too high for "a community completely dependent on trade to deny itself even a small part of that trade."12 Later boycotts were entered into reluctantly, only after many threats and accusations from fellow colonists such as the disgusted New Yorkers who maintained that Newporters "have greatly advanced their private interests, and injured the cause of Liberty...."13 Always guided by the pursuit of profit, only when political and economic interests coincided would the ever-opportunistic Newporters be induced to act.

The increasingly heavy patrol of Newport harbor disrupted trade and vexed many city residents. Not surprisingly, then, it was the seizure of trading vessels, the very lifeline of the Newport economy, which led an impassioned crowd to demolish the H.M.S. Liberty in 1769. Indeed,

10 Cohen, Joel A., "Rhode Island Loyalism and the American Revolution," Rhode Island History, Vol. 27, No. 4 (October 1968), 97.

11 as quoted in Crane, A Dependent People, 127.

12 Crane, $A$ Dependent People, 117.

13 as quoted in Crane, $A$ Dependent People, 118. 
"anything that threatened Newport's trade warranted retaliation."14 Acts of defiance to the crown litter the city's history in these years: skirmishes between British seamen and local residents, break-ins, smuggling, firing on British vessels like the St. John and the Maidstone in Newport harbor, as well as full-scale rioting. Elaine Forman Crane is convinced that "economic grievances precipitated Newport's entry into the war" and that Newporters in general were no ideologues. ${ }^{15}$ Yet the Revolutionary cause inextricably linked economic issues with political philosophy. To adhere to the Revolution on the basis of economic self-interest was to necessarily adhere as well to the republican theories by which that revolt was justified. Thus while its residents decried that British high-handedness would bring them "a total end of all prosperity" did the Newport Mercury emblazon its banner with the maxim "Undaunted by TYRANTS, ------ We'll Die or be FREE."16 So too did one local artist depict Newport as a city that illustrates "the Advantages which LIBERTY gives to COMMERCE."17 Yet because gender relations played a pivotal role within republican philosophy, Newport men on the eve of the American Revolution would come to equate their economic survival, nay, their very identities, with the preservation of a particular set of gendered ideals championed by republicanism yet in important ways conflicting with trends already well underway within the seaport community. To understand the anxiety Newporters exhibited over the city's female inhabitants in the Revolutionary era, then, it is essential to understand the connections between gender and republicanism.

14 Crane, A Dependent People, 113.

15 Ibid., xi.

${ }^{16}$ Newport Mercury, January 1, 1770.

17 as quoted in Crane, A Dependent People, 114. 
Gender as a foundation for societal organization and expression has been well documented by historians in recent years. Far from confining themselves to the private social interactions between men and women, historians of gender have shown that gender relations inform the construction of meaning for politics, economics, and religion as well. As Joan Wallach Scott puts it, gender as an organizing force "can be found in many places, for the meaning of sexual difference are invoked and constructed as part of many kinds of struggles for power." 18 Indeed, as Jay Fliegelman notes, the rhetoric utilized to endorse American independence from Great Britain was informed by gender as a basic framework for its vision of ideal relationships of all types in American society.

Fliegelman has persuasively argued that Lockean pedagogy effected a considerable change in the way eighteenth century Americans perceived human relationships. Rapidly discarding the religious notion of innate human depravity and Original sin, Americans embraced the concept of a malleable human nature which, if shaped by parental affection and example rather than force and precept, could mold a more sanguine, moral society based on what other historians have termed "affective individualism." Within such a society, authority would be characterized by benevolence, not constraint. Parents would guide male children toward an independent adulthood with a gentle hand and daughters would find their liberation in a marital union of their own making. "Central to the rationalist ideology of the American Revolution," Fliegelman writes, "was the belief that in an ideal world all relationships would be contractual."19 Men and women would

\footnotetext{
18 Scott, Joan Wallach, Gender and the Politics of History, (New York, N.Y.: Columbia University Press, 1988), 6.

19 Fliegelman, Jay, Prodigals and Pilgrims: The American Revolution Against Patriarchal Authority, 1750-1800, (Cambridge, England: Cambridge University Press, 1982), 123.
} 
marry because they loved each other voluntarily, not because of parental pressure. This development has lead Jay Fliegelman to conclude that "[t]he struggle for American independence and for subsequent federal union was intimately related to, and ideologically reflected in, a national affirmation of the sacred character of affectional and voluntaristic marriage."20 That eighteenth century Americans should stake so much, indeed the very future of their society, on the institution of marriage was not, however, such a radical departure from their collective past. Actually, the marital bond had long been regarded throughout the colonies as essential to the health of a society.

Though, as Jan Lewis notes, "eighteenth-century thought placed the family and the state on one continuum, that of 'society,' and did not yet... erect a barrier between the private sphere of family and the public one of the world...," this conception of society was in fact rooted in earlier thought. From the very beginning of settlement, colonists had conceived of family relations as integral to the construction of society. Seventeenth century colonists, particularly the Puritans, insisted that "family disorder or disharmony of any sort rippled through the rest of society."21 The family was a microcosm of society, the "little commonwealth." 22 As the genesis of family life, marriage was viewed as particularly important in ensuring social concord. "For the sake of order, morality, and its own economic interests, the community demanded stability in marriage." 23 Marriage, then, had always been at the center of the colonial notion of social order and stability, and

\footnotetext{
20 Ibid., 129.

${ }^{21}$ Wall, Helena M., Fierce Communion: Family and Community in Early America, (Cambridge, Mass.: Harvard University Press, 1990), 11.

22 see Demos, John, A Little Commonwealth: Family Life in Plymouth Colony, (New York, N.Y., 1970).

${ }^{23}$ Wall, Fierce Communion, 80.
} 
though many of the terms of marriage had been changed by the eighteenth century, this notion remained. Thus could John Witherspoon, writing shortly before the Revolution, proclaim that "marriage has ever been considered by every wise state the sinew of its strength and the foundation of its true greatness." ${ }^{24}$ And no one could make more clear the intricate connections in the eighteenth century between marriage, stability, liberty, and prosperity than an ardent patriot like Benjamin Franklin.

Franklin's discussions of marriage are replete with references to Enlightenment and republican principles. Marriage, he would inform a friend in 1745, "is the most natural State of Man, and therefore the State in which you are most likely to find solid Happiness." On another occasion, refuting the notion that in matrimony man is but a slave in bondage "for every Woman is a Tyrant," he maintained that matrimony was instead an avenue of liberation, at least for men. ${ }^{25}$ "If there be any Bondage in the case, 'tis the Woman enters into it, and not the Man." 26 "Nor does a Man lose his Liberty, but encrease it," Franklin continues. Significantly, his argument hinges on assumed connections between marriage and stability as well as liberty and economic prosperity:

A man being fixt [married] in Life minds his Business better and more steadily; and he that cannot thrive married, could never have throve better single;... a Man that has a Wife and Children, is sooner trusted in Business, and can have Credit longer and for larger Sums than if he was single, inasmuch as he is looked upon to be more firmly settled...27

\footnotetext{
${ }^{24}$ as quoted in Lewis, Jan, "The Republican Wife: Virtue and Seduction in the Early Republic," reprint American Vistas, ed. by Leonard Dinnerstein and Kenneth T. Jackson, (New York, N.Y.: Oxford University Press, 1995), 178.

25 The Papers of Benjamin Franklin, Volume 2: January 1, 1735 through December 31, 1744, ed. by Leonard W. Labaree (New Haven, Conn.: Yale University Press, 1960), 22.

26 Ibid., 23.

27 Ibid., 23-24.
} 
The married man, according to Franklin's formulation, then, is at once the symbol of stability, liberty, and economic opportunity. Franklin's interpretation of matrimony reveals the conglomeration of old and new ideas that institution represented to colonists on the eve of independence.

Marriage had long been associated with stability and economic opportunity. Jeanne Boydston notes that "Seventeenth-century Europe was still a society in which... a man could anticipate having in a wife not only a companion and a source of comfort, but also 'a servant for profit.' The English immigrants whose culture would so dominate American experience carried this view with them to the colonies." 28 Yet by the eighteenth century Americans had largely discarded notions of compulsion within matrimony so that "Revolutionaryera writers held up the loving partnership of man and wife in opposition to patriarchal dominion as the republican model for social and political relationships." 29 Order, liberty, prosperity - to colonists of the Revolutionary generation all were dependent on marriage. As noted earlier, however, marriage in late eighteenth century Newport was anything but stable. At the very time marriage was touted as a symbol of the Revolution and the foundation of a new republic, in Newport the institution was under great stress.

Newport fits well the patterns of demographic change several historians have noted characterized older colonial towns and cities in the eighteenth century. As towns aged, so too did their populations. "The settlers of new towns," writes John Demos, "were generally young people, presumably because the opportunities for gaining wealth and prestige were greater there than in the more established communities of their birth and also because the

${ }^{28}$ Boydston, Jeanne, Home \& Work: Housework, Wages, and the Ideology of Labor in the Early Republic, (New York, N.Y.: Oxford University Press, 1990), 5.

${ }^{29}$ Lewis, "The Republican Wife," 161. 
problems of town building required a youthful strength, imagination, and resourcefulness." 30 That men also predominated in the founding of new communities left many older towns with a generally older and more female populace. Indeed, Elaine Forman Crane has discovered that Newport in the late colonial era "had a larger percentage of older people generally than the colony as a whole," a pattern Lynne Withey believes "suggests that younger people tended to move out of the state toward the end of the eighteenth century." ${ }^{11}$ Both historians have noted as well the profound sex ratio imbalance that characterized the city at this time.

Describing the process of feminization of colonial communities, Susan Grigg writes that "[m] ore men than women were in each wave of settlement, but in each newly settled region the balance shifted first toward rough equality in numbers and then toward an excess of women as natural increase overwhelmed the early imbalance..."32 By the middle of the eighteenth century the sex ratio in Newport had just about evened out. In 1755, during the nascent stages of the French and Indian War, men comprised about fiftyone percent of the seaport's adult white population while women constituted forty-nine percent. However, only nineteen years later, in 1774 , the sex ratio had dramatically shifted in favor of women. In that short time, white adult women had increased in number twice as rapidly as men and by the eve of the Revolution acutely outnumbered men, far beyond natural variance. This overabundance of women in relation to men had tremendous ramifications for gender relations in Newport on the eve of the Revolution.

\footnotetext{
30 Demos, John, "Families in Colonial Bristol, Rhode Island: An Exercise in Historical Demography," The William and Mary Quarterly, 25 (January 1968), 49.

31 Crane, 70; Withey, Lynne E., "Household Structure in Urban and Rural Areas: The Case of Rhode Island, 1774-1800," Journal of Family History Vol. 3 (1978), 42.

32 Grigg, Susan, "Toward a Theory of Remarriage: A Case Study of Newburyport at the Beginning of the Nineteenth Century," Journal of Interdisciplinary History, Vol. VIII:2 (Autumn 1977), 196.
} 
In regard to the effect of the sex ratio imbalance on marriage in Revolutionary Newport, Elaine Forman Crane contends that "[b]ecause of the sexual imbalance, there were a number of unmarried females in the community whose chances of marriage decreased as the imbalance became more severe." ${ }^{33}$ Moreover, connecting sex ratio to town size and economic orientation in Revolutionary Rhode Island, Lynne Withey has discovered that "[i]n Newport,... women headed about 20 per cent of all households throughout this period, compared with about five per cent in subsistence agriculture towns, six to seven percent in commercial towns, and seven to eleven per cent in smaller port towns and towns near cities." ${ }^{34}$ Recall that the emergence of a large-scale, overseas commercial-based economy in eighteenth century Newport had wrought tremendous change in the lives of its families. The sea drew increasing numbers of men away from their families, forcing wives to take a greater role in daily decision-making and straining the efficacy of marital coverture. Indeed, wives often found themselves living lives more akin to widowhood than to matrimony and in fact widowhood was always just around the corner for these women. When tragedy struck the seaport, as it increasingly did in the eighteenth century, the effect was very often to tear at the "ties that bind." For instance, the destruction of two Newport vessels in a vicious snowstorm the day before the Christmas of 1745 unmade many a marriage and reminded all of the precarious nature of both life and marriage. Roughly four hundred men were lost that day. ${ }^{35}$ Not surprisingly, young widows were a common characteristic of colonial seaport communities. While in Newport many wives

\footnotetext{
33 Crane, A Dependent People, 75.

34 Withey, "Household Structures in Urban and Rural Areas," 43.

35 this episode is recounted in James, Sydney V., Colonial Rhode Island-A History, (New York, N.Y.: Charles Scribner's Sons, 1975), 270.
} 
were widowed at a young age due to tragedies at sea, evidence suggests that there were many older widows in the city as well.

In her study of the early nineteenth century Massachusetts seaport community of Newburyport, Susan Grigg has determined that, on the whole, colonial women were much less likely to remarry when widowed than were men and, in fact, age was an important factor in governing rates of female widowhood and remarriage, for though "[r]emarriage became progressively less likely for women as the age at widowhood increased,... among widowers the remarriage rate did not vary with age except at the extremes..."36 A lack of evidence that wealth, poverty, or number of children had a strong impact on the likelihood of remarriage, Griggs submits, implies that the desire (or lack thereof) to marry may be as important a determinant in remarriage rates as need or opportunity. Similarly, Nancy Cott has discovered that a distinct rise in the proportion of never-married women characterized eighteenth century colonial America. For families formed in the first half of the century, nine percent of their daughters would never marry. Those formed in the Revolutionary era, however, would see twelve percent of their daughters remain single. While numbers alone indicate that Newport's women were increasingly unlikely to marry, choice as well as circumstance may have mitigated the pervasiveness of the marital bond in Newport. The situation led one concerned resident to conclude that marriage in the city had grown "out of fashion." 37

Accentuated by the fact that at any given time, scores of eligible men were away at sea, women, particularly unwed women, seemed to be flooding the seaport. The churches, for instance, were inundated with women.

36 Grigg, "Toward a Theory of Remarriage," 201.

37 as quoted in Skemp, A Social and Cultural History of Newport, Rhode Island, 240. 
"Eighteenth century records indicate that women outnumbered men in Newport churches three or four to one, while in the rest of the American colonies that figure remained closer to two to one." 38 Furthermore, as the service-sector of the local economy grew, women gained a greater presence in other sections of the public realm. As previously illustrated, by the time of the Revolution, Newport women had found their way into a wide variety of economic endeavors and were engaging men as counterparts in the public world of business. Daniel Scott Smith has found that "[g]ainful employment was most characteristic of younger widows in urban areas. An astonishing 80 percent of the female household heads (a group overwhelmingly composed of widows) enumerated in the 1810 census in the central sections of Philadelphia were listed with occupations." 39 Gloria Main concludes that this "growing ability of women to earn money and conduct business at the local store [in this era] can be viewed as a positive good, giving them greater control over their own lives."40 Indeed, as has been shown, the most consistent characteristics of women who appeared in the local courthouse to prosecute cases in Newport were their unwed and capital-earning status. Anecdotal evidence suggests that such a sense of control may have even begun to penetrate the thinking of women in wedlock.

"Even before the [Revolutionary] war," insists Lee Virginia ChambersSchiller, "the family served as the arena in which women asserted their individuality and desire for independence."41 Suggesting as much, one contributor to the Newport Mercury, adjusting his inquiry "to the Meridian of

\footnotetext{
38 Skemp, A Social and Cultural History of Newport, Rhode Island, 238.

39 Smith, Daniel Scott, "Inheritance and the Social History of Early American Women," Women in the Age of the American Revolution, eds. Ronald Hoffman and Peter J. Albert (Charlottesville, Virginia: University Press of Virginia, 1989), 59-60. 40 Main, "Gender, Work, and Wages in Colonial New England," 65.

41 Chambers-Schiller, Lee Virginia, Liberty, A Better Husband, (New Haven, Conn.: Yale University Press, 1984), 2.
} 
Rhode-Island," mused in the late summer of 1764 "Whether if Women had no Portions, we should then see so many unhappy and unfruitful Marriages?"42 Both the question and the publisher's decision to print it betray a sense of anxiety about the health and stability of the institution not uncharacteristic of the city's community members as friction with Great Britain began to increase at the close of the French and Indian War. In fact, changing demographics, dubious economic stability, political tensions with Britain, and the eighteenth century emphasis on voluntarism all combined to make Newporters very uneasy about the city's women and apprehensive about the state of marriage in their community as the tide of revolution swelled around the seaport.

The dominant discourse which subsequently arose around matrimony upheld the institution as the true mark of womanhood and subtly challenged the femininity of women existing outside of the "ties that bind." At a time when marriage was infused with notions of political and economic prosperity, such women were perceived as threats to individual and community stability. "That MAN who resolves to live without WOMAN, or that WOMAN who resolves to live without MAN, are ENEMIES TO THE COMMUNITY in which they dwell," went the prevalent wisdom, "INJURIOUS TO THEMSELVES, DESTRUCTIVE TO THE WORLD, APOSTATES TO NATURE, and REBELS AGAINST HEAVEN AND EARTH."43 Implicit in this discourse as well were issues of female autonomy firmly, if subtly renounced, thus confirming the place of Newport patriots in Linda Kerber's conclusion that "[f]aced with a choice between coverture and independence, the Revolutionary chose coverture." 44

\footnotetext{
42 Newport Mercury, September 3, 1764.

43 as quoted in Lewis, "The Republican Wife," 178.

44 Kerber, Linda, Women of the Republic, (Chapel Hill, N.C.: University of North Carolina
} 
The Newport Mercury was instrumental in the transmission of the discourse on marriage among Newporters. Michael Warner has documented the significance of the printed word to eighteenth century Americans, made most evident by the burgeoning number of newspapers that came into existence in that century. To Warner, such a development represented a new understanding among the colonists of the value of print. "By 1765," Warner writes, "print had come to be seen as indispensable to political life, and could appear to men such as [John] Adams to be the primary agent of world emancipation." 45 However, it is important to remember the gendered dimensions of linguistics in colonial society. "Writing was a specialized skill primarily employed by the male-dominated realms of commerce and law; it was especially common for women to be taught reading but not writing." 46 This fact was of substantial consequence in structuring men's and women's respective relationships to the colonial newspaper and gave the papers a distinctly masculine bent. In their examination of the Pennsylvania Gazette, an eighteenth century paper representative of its era, Charles Clark and Charles Wetherell observed of the newspaper that "[a]lthough its involvement in provincial life extended beyond trade and commerce, it clearly centered on economic matters of 'getting and spending'."47 As men dominated the substance and tone of content, colonial newspapers reflected masculine concerns. Women essentially related to the newspaper (if at all) as readers and not as active contributors of opinion. With the establishment of the Newport Mercury in 1758, then, the city's men were given a new avenue of

Press, 1980), 136.

45 Warner, Michael, The Letters of the Republic: Publication and the Public Sphere in Eighteenth-Century America, (Cambridge, Mass.: Harvard University Press, 1990), 32. 46 Ibid., 16.

47 Clark, Charles E., and Wetherell, Charles, "The Measure of Maturity: The Pennsylvania Gazette , 1728-1765," The William and Mary Quarterly Vol. XLVI, No. 1 (April 1989), 281. 
discourse with which to promote their convictions. Of this development, Sheila Skemp writes, "Indeed the Newport Mercury in this period almost supplanted the sermon as a means of moral propaganda." 48 While much of the newspaper's moralizing on matrimony reflected the republican celebration of the institution, evident within many of the pieces are anxieties over the state of marriage in the seaport as well as implicit, and at times explicit, antipathy toward women existing out of wedlock.

The capacity of certain types of women to arouse anxiety and enmity in men has been well documented by historians. The rise of commerce in England as early as the sixteenth century, for instance, proved a formula for a verbal backlash against women. Women participating in the new economy were accused by some as exhibiting an "unfeminine" assertiveness and autonomy. Of these critics, Carol Karlsen writes that "more than likely it was not so much women's increasing independence in the wake of commercial development that troubled these commentators; rather it was the increasing visibility of women within their traditional but increasingly commercialized occupations," a situation, remember, that also characterized late eighteenth century Newport.49 The proposed solution to some Englishmen then, to "keep their wives in their houses" as one London manifesto put it, was one that would be later reconfigured by their American descendants in Newport. Given the republican significance attributed to marriage in the Revolutionary era, it was suggested (after all, marriage was now supposed to be voluntary on the part of the woman) that marital bondage was a far superior state of existence for females than was anything outside the institution.

\footnotetext{
48 Skemp, A Social and Cultural History of Newport, Rhode Island, 429.

49 Karlsen, Carol F., The Devil in the Shape of a Woman, (New York, N.Y.: Vintage Books, 1987), 160-161.
} 
On Monday, February 28,1763, readers of the Newport Mercury were treated to a curious piece entitled "A Receipt to make Love Powder, for the Use of the Fair Sex." The composition advised the Newport woman to "Let your Desire be to please all men honestly; and neglect not your duty to God to pay Attendance to any earthly Concern."50 "Learn to command Respect," it continued, "by your obliging, agreeable, modest, and virtuous Behavior." Of course, the entire premise of the piece, as well as the decision to print it, was that the city's women were in need of such direction. Instruction in the art of creating attraction would aid in reversing the seeming trend away from wedlock. When supplemented with the advice "which you have already received from your Friends, Relations, and Bible," the recipe, promised its author, "if ma[d]e a daily Practice... is the most powerful Provocative to Love upon Earth." Proof of the power of love and the felicity of marriage was presented a month later in a story recounting the union of two elderly widows, John Mason and Elizabeth Armitage, in Leeds, England, the previous year.

Both residents of the Ealand workhouse in Leeds, John and Elizabeth's acquaintance blossomed into love and the two happily resolved to marry in 1762. The announcement of their nuptials was greeted with great enthusiasm from, the article insinuates, almost the entire community of Leeds:

They were brought from the workhouse to Church in a post-chaise, with suitable attendance; from whence they adjourned to the Parish-clerk's, where they dined with the Town Officers and other principal inhabitants. After dinner the Bride walked a minuet with one of the attendants, as did the Bridegroom with a young woman of the neighborhood; and to shew his extraordinary agility [he was 75], he would afterwards divert the company by dancing a hornpipe. ${ }^{51}$

50 Newport Mercury, February 28, 1763.

51 Newport Mercury, March 28, 1763. 
The editor's decision to re-print the story for Newporters indicates the importance attached to the subject. The story would have resonated with meaning for city residents, connecting as it does issues of marital and economic status. The correlation in the eighteenth century between widowhood and poverty was here made explicit. Though in Newport, as noted earlier, widows likely constituted but a small portion of the city's workhouse and almshouse residents, as a whole they were undeniably a distressed lot. In fact, Elaine Forman Crane has observed that "[w]omen as a group were considerably less affluent than men..."52 At a time when the number of poor in the seaport was increasing, "resentment of them was also vocalized more frequently in these years, as the cost of charitable maintenance often proved to be an unbearable drain on Newport's prosperity."53 As the article suggested, marriage would be the route out of such misery, a source of alleviation for the larger community as well as the newlyweds. The unusual celebration of John and Elizabeth's union thus had distinct economic overtones as did the bride's understanding of her marriage. As she expressed it, she and John "had better be married than do worse." 54 This was a message the Newport Mercury would systematically reinforce in piece after piece regarding the marital bond.

As Charles Clark and Charles Wetherell have noted, colonial newspapers like the Newport Mercury obtained much of their material from European sources. Not surprisingly, then, several articles on marriage in the paper originated in England. Yet the editing process was performed in Newport and reflected "a growing concern to understand and serve the particular

\footnotetext{
52 Crane, A Dependent People, 71.

53 Skemp, A Social and Cultural History of Newport, Rhode Island, 335.

${ }^{54}$ Newport Mercury, March 28, 1763.
} 
readership that the publishers wished to cultivate."55 In August of 1763 appeared a rather bizarre story in the Mercury recounting the demise of a young English woman scorned by her lover and rejected by the "blissful bonds" of marriage. According to the article, the "young Gentlewoman, about 19 Years of Age, was found hanging in her Chamber, at her Father's house in Westminster." 56 Distraught over a broken promise of marriage, the griefstricken woman decided death was preferable to the shame of rejection and a life outside of marriage. Implicit within this story and numerous others published in the Mercury during the Revolutionary era is a subtle, yet consistent denigration of an existence outside of wedlock. Marriage is portrayed as an eminently more desirable state of existence than either widowhood or remaining single. Often, as in the above case, the single or widowed marital status is presented to the reader as a fate worse than death. Those who read the Newport Mercury on September 5, 1763 were treated to just such a point of view.

Though its ostensible purpose was to "soften the Mind of Man, and make the Heart better" through the fictional account of a young couple's bliss shattered by death, the story that appeared on the front page of that day's newspaper contained an underlying denunciation of widowhood.57 After "the celebrated Lovers were at length joined in Marriage," the bridegroom is "obliged to go into a Foreign Country, to take care of a considerable fortune... [in order to] improve their moderate Circumstances." 58 The husband is analogous in this regard to the multitude of Newport men who themselves were attempting to advance family fortunes by traversing the ocean. While

\footnotetext{
55 Clark and Wetherell, "The Measure of Maturity," 303.

56 Newport Mercury, August 1, 1763.

57 Newport Mercury, September 5, 1763.

58 Ibid., 1.
} 
waiting for her husband's return, the young bride would occupy her time with walks along the beach with a friend "observing the setting of the Sun, the calm Face of the Deep, and the silent Heaving of the Waves, which gently roll'd toward them, and broke at their Feet."59 They were obviously situated in a town, like Newport, on the water, and so the wife's situation would be very familiar to the women of Newport, who themselves frequently had absented loved ones overseas. One evening, while on the beach, the woman and her friend "saw something float on the Waters" which they took to be a treasure chest. 60 But as the "chest" neared, the two realized that instead "it was a human Body."61 Pitying the deceased and the relatives surely left behind by the death, the women were about to leave when the bride's companion

shreik'd out Oh, my Cousin! and fell upon the Ground. The unhappy Wife went to help her Friend, when she saw her own Husband at her feet, and dropt in a Swoon upon the Body. An old woman, who had been the Gentleman's Nurse, came about this Time to call the Ladies into Supper, and found her Child (as she always call'd him) dead on the Shore, her Mistress and Kinswoman both lying dead by him. Her loud Lamentations, and calling on her young Master, soon awakened the Friend from her Trance: but the Wife was gone for ever. ${ }^{62}$

Significantly, this Newport Mercury piece reinforces the message that life without a husband was simply not worth living. This horrific story's resemblance to the nature of eighteenth century Newport are too striking to ignore. As increasing numbers of men were putting out to sea, they left increasing numbers of wives behind and created growing numbers of widows. Carol Karlsen has noted the role of such socio-economic transformation on gender perceptions in seventeenth-century Salem, Massachusetts. The

\footnotetext{
59 Ibid., 1.

60 Ibid., 1.

61 Ibid., 1.

62 Ibid., 1.
} 
infamous witch trials, she contends, were rooted in a growing fear of the "independent" woman, the seed of which was planted by the changes wracking the town's traditional socio-economic order as it developed into a thriving seaport community. Amidst the change, apprehension of widowhood sharpened. As the widow "could hold and dispose of property as independently as the males... [s] he occupied a relatively autonomous position in the structure of society."63 Though fortunately lacking the same intensity as Salemites, Newporters by the mid-1700s were increasingly apprehensive about the widow. As the city's economy became ever more "troubled" and political tensions with the British mounted, the widow was interpreted under republican terms as a destabilizing force herself by failing to re-wed. As the story of John Mason and Elizabeth Armitage illustrated, re-marriage was to be encouraged and celebrated as a commendable act. Another piece that reinforced this persuasion recounted for Newporters the unfortunate trials of Nehemiah Liscomb of Stoughton, Massachusetts.

In 1763, Liscomb married for the fourth time in as many years. Having lost his three previous wives to death in rapid succession, he nevertheless continued to refuse death's design for him as a widower and defiantly remarried, maintaining a precarious yet tenacious hold on that venerable institution. His efforts were hailed in a poem which cast him in the role of the classical hero, favored by a patron goddess to achieve greatness. Here was the eighteenth century inclination that historians such as Bernard Bailyn have observed characterized Revolutionary-era political writings applied to matrimony, hence casting Liscomb's actions in distinctly political terms:

${ }^{63}$ Karlsen, Carol F., The Devil in the Shape of a Woman, (New York, N.Y.: W.W. Norton and Company, 1987), 190. 
The Tyrant Death envied his happy Life, And thrice bereav'd him of a virtuous Wife;

But know, grim Tyrant, all thy Darts are Vain, Thy wounds, repeated oft, are heal'd again;

Venus beholds her Hero still with Pride

And gives another Virgin for his Bride. ${ }^{64}$

Indeed, what is truly striking about references to women and marriage in the Newport Mercury is the extent to which they incorporated the language of the great political and economic issues of the day, and so substantiate the conclusion that matrimony would come to constitute a crucial locus for Revolutionary ideology. An early expression of this can be found in the Mercury's 1763 reprinting of an anonymous composition entitled "THE MAID'S SOLILOQUY."

Originally published in South Carolina, the soliloquy was introduced to the printer of the Mercury by an individual who supposed that "[t]he following Lines... will not be disagreeable to any of your Readers, except those who have, or intend to have, no Connection with the Fair Sex." Obviously directing this preface to the soliloquy toward men, who were regarded as the "Readers," the writer meant by this language that the piece would not appeal to the few men uninterested in marriage. For the rest of the city's men, however, the composition would indeed be pleasing, as it reinforced the notion that though marriage entailed the loss of autonomy for women they would still voluntarily choose to forfeit their independence in order to marry.

"Marriage, thou pleasing, and yet anxious thought!" the soliloquy proclaims, "Through what variety of hopes and fears, Th' unchanging state in prospect lies before me... in wedlock, women must obey... I wed --- my liberty is gone forever..."65 By existing outside the institution of marriage Newport's 
singlewomen, who never married, and widows, who did not re-enter wedlock, seemed symbolic espousals of independent existence and silent subscribers to such anti-matrimonial arguments. However, the soliloquist at length determines that such women are misguided. Marriage is a gift; it gives much more than it takes. In matrimony, "happiness from time itself [is] secur'd; Love first shall recompence my loss of freedom... And when the charms of beauty shall fade away,... Then virtuous friendship shall succeed to Love: Thus blest, I'll scorn grim death..."66 By properly thinking it through, women would realize that marriage was a blessing, not a curse. In fact, marriage represented the epitome of rationalist thought, for as Newporters would be reminded several months later, "the Affection between Lovers and Friends is founded on Reason and Choice."67 The choice of marriage was a natural one for a woman, the soliloquist judged, as "'Tis nature's self that points out an alliance, And intimates an husband to the sex." By implication, to remain unwed was at once irrational and unnatural.

"When courtship and marriage are infused with political meaning," writes Jan Lewis, "women inevitably and inescapably become political beings," a process readily apparent in the pages of the Newport Mercury during the Revolutionary era. ${ }^{68}$ The degree to which women had become politicized in Newport as early as 1764 was evidenced by a series of anonymous essays published in the Mercury over the course of several weeks during the late summer of that year. The essays proposed the alleviation of political and economic instability within the colony through the stabilization of gender. "The Colony of Rhode Island is confessedly decaying in its Circumstances," wrote the essayist, "but that should not discourage any intelligent Persons

\footnotetext{
66 Ibid, 2.

67 Newport Mercury, September 5, 1763.

68 Lewis, "The Republican Wife," 168.
} 
from pointing out a Remedy."69 By "restoring them to their primitive and most ancient Dignity and Employment," Newport's women, the author contended, promised to be the means by which to restore prosperity to the troubled seaport. ${ }^{70}$

The source of the problem, the articles intimated, was twofold: 1) the colony's overwhelming dependence (most evident in Newport) on commercialized shipping and 2) the women's abandonment of that most domestic of occupations, spinning. As Mary Beth Norton reminds us, "no household task was more time-consuming or more symbolic of the female role than spinning."71 The conviction that such a traditionally feminine responsibility needed to be "restored" suggests a contemporary recognition of the correlation, detailed throughout this work, between changes in the nature of the local economy and the nature of women's livelihoods. It indicates that women were indeed spending more time on other endeavors. As the transformation of the area's economy had effected a shift away from home production, Rhode Islanders were left dangerously dependent on other colonies and other nations for its prosperity. "The People of this Colony are daily taught, from innumerable Lessons or Instances that are but too conspicuous in the numerous Shops, Stores, and Warehouses, how backward and ignorant we are in the manifold Branches of Manufacture necessary or superfluous."72 The result, it was argued, was the "decaying" condition of the colony, where, as the Town Council had noted some months earlier, increasing numbers of poor "have no Employ."73 The increased presence of the British navy in Newport harbor and the threat it represented to the city's

\footnotetext{
69 Newport Mercury, August 27, 1764.

70 Newport Mercury, September 3, 1764.

71 Norton, Liberty's Daughters, 15.

72 Newport Mercury, September 10, 1764

${ }^{73}$ Newport Mercury, January 2, 1764.
} 
shipping interests was only exacerbating an already unpleasant situation. The articles proposed that the solution to the region's economic woes lay with industrial development, specifically the cultivation of cloth production, as "Without Industry no Country can Flourish."74 In fact, it was promised, "Industry will retrieve any Kingdom, Colony, or Family."75 One need only look to Londonderry, New Hampshire for evidence of its restorative potential.

The Township of Londonderry, in New-Hampshire, is the most industrious of any in New-England, and therefore its Inhabitants are better-cloathed, have better Houses, and are not only free of Debt, but, in general, moderately affluent. The flourishing Circumstances of these honest, frugal People, can be ascribed to no other Cause, but an early, constant Employment of their Men, Women, and Children, but more especially of their women. ${ }^{76}$

Indeed, women were the crucial component to the success of such a plan. Adding an economic dimension to a republican formula which made women the keepers of political virtue, the essayist stressed that "I firmly believe the Fair Sex are more capable than our's of introducing this System of Virtue."77 If Rhode Island women placed more emphasis on the virtues of spinning and weaving, they could systematically reduce the colony's dependence on foreign goods and induce a pride in local manufacture bordering on patriotism. Significantly, there is evidence that some did not take too kindly to the suggestion that women need to return to the loom, for the following week the author was forced to explain to readers that "it is not my Intention to demean or debase [women], but exalt and adore them." 78 Still, his suggestions were popular enough to be given substantial space in the Mercury over the course of several weeks. In fact, so popular were his ideas that they were soon

\footnotetext{
74 Newport Mercury, August 20, 1764.

75 Newport Mercury, August 27, 1764.

76 Ibid., 3.

77 Newport Mercury, August 20, 1764.

78 Newport Mercury, August 27, 1764.
} 
reprinted in both Boston and Portsmouth, indicating that in both of these seaports women needed to be "restored" to their natural roles as well.

Significantly, while Newport's women later participated in several spinning contests during the Revolution, this particular campaign was never realized. Indeed, its designer would acknowledge that "I am sorry to tell you, that I have not been waked in a Morning by the Music of a SpinningWheel."79 Unlike the later meetings, this scheme necessitated a lasting change, a permanent "Reformation" as the author of the Mercury articles put it, in women's economic behavior. At a time when the city's women were increasingly diversifying their role in the local economy, the program in essence advocated a constriction of economic opportunity. By contrast, temporary spinning meetings possessed completely different connotations. As Laurel Thatcher Ulrich suggests, these gatherings may well have constituted "an early form of women's religious or charitable activity, a precursor of the nineteenth-century missionary or educational societies that raised money or sewed shirts for traveling ministers or divinity students." 80 Hence were these latter gatherings well attended among women, while the former design was criticized for "the Severity of [the] Plan, when it falls in Course (as in Truth it often may) to address the Ladies...." 81 Still, though controversial for its frankness, the proposal represents only the most extreme application of gender as a response to the turmoil wracking the once prosperous and harmonious city by the sea.

It is important to bear in mind that such pieces were emerging at the very time order and stability were disintegrating within the city. Mob scenes were

79 Newport Mercury, September 24, 1764.

80 Ulrich, Laurel Thatcher, "'Daughters of Liberty': Religious Women in Revolutionary New England," Women in the Age of the American Revolution, eds. Ronald Hoffman and Peter J. Albert (Charlottesville, Virginia: University Press of Virginia, 1989), 222.

81 Newport Mercury, August 27, 1764. 
growing all too common and "[a]s Thomas Vernon noted with disgust, law and order no longer meant very much in Newport."82 By no means were females immune from the chaos of the era, and, as the widow Charity Whitford discovered in the autumn of 1775 , women as well as men could be victimized in such a highly charged atmosphere.

On the evening of September 15, Charity was the target of mob violence. Around one o'clock in the morning, William Howard and William Maccauley, along with unidentified others, "with Guns and certain Instruments or Weapons called Bayonets, did forcibly enter into the Dwelling House of Charity Whitford" and attack the startled woman. ${ }^{83}$ The men menaced Whitford so that her daughters fled the house to find help, awakened their uncle, the cooper Jonathan Chadwick, and "prayed for God Sake that he wou'd make haste for that People wou'd murder [their] Mother."84 Indeed, the invaders had wounded Whitford's hand to the extent "whereof the Thumb of the said Charity Whitford was much hurt." When her brother arrived to rescue Charity from further harm, he himself was seized by the mob, dragged through the streets, and beaten so severely that "he was faint and sick thro' the great loss of Blood."85 Newport had truly become, as Elaine Forman Crane puts it, "a town at war with itself." Replete with political and economic connotations, the local discourse on gender also reflected the social dislocation brought on by the turmoil of the era.

Linda Kerber has hypothesized that the celebration of domesticity evident by the early nineteenth century may well have been at least in part a reaction to the strains placed on family unity during the Revolutionary war.

\footnotetext{
82 Crane, A Dependent People, 116.

${ }^{83}$ Rex $v$. William Howard, September 1775, R. I. Sup. Ct. Records, Newport District, Record Book F, case file.

84 Examination of Jonathan Chadwick, Rex $v$. William Howard case file.

85 Ibid.
} 
"The war was so disruptive to family life," she writes, "that one begins to wonder whether the cult of domesticity - the ideological celebration of women's domestic roles - was not in large measure a response to the wartime disruption and threat of separation of families." 86 If so, evidence from Newport suggests that this process may have begun even before the war commenced. Historians have noted the ways in which political loyalties and economic anxieties could splinter individual families as well as the larger communities and have discovered such rifts in numerous Newport households during the Revolutionary era, even in prominent families like the Vernons, Wantons, Coggeshalls, Almys, and Malbones. ${ }^{87}$ Remember the various court cases documented in the preceding chapter that pitted relatives against one another. It is not unreasonable, then, to suggest that the celebration of matrimony in the local discourse was developed as a rejoinder in part because familial instability within the seaport renewed interest in and affection for the institution. Homilies praising marriage, such as the one appearing in a 1770 edition of the Mercury entitled "The Bachelor's Reason's for taking a Wife," consequently addressed social as well as political and economic problems in Newport by urging residents to recognize "That honest Wedlock is a glorious thing." 88 Not coincidentally, the composition is laden with correlation between wedlock and social, political, and economic stability and security. Of such a gendered discourse, Carol Cohn writes, "human characteristics are dichotomized, divided into pairs of polar opposites that are supposedly mutually exclusive..."89 By implication, then, singlehood is

\footnotetext{
86 Kerber, Women of the Republic, 47.

87 see, for instance, Crane's A Dependent People, pg. $153 n 114$.

88 Newport Mercury, August 20, 1770.

89 Cohn Carol, "War, Wimps, and Women: Talking Gender and Thinking War," Gendering War Talk, eds. Miriam Cooke and Angela Woollacott, (Princeton, N.J.: Princeton University Press, 1993), 229.
} 
associated in these pieces with the instability being endured by Newporters at the time.

The consistent message of "The Bachelor's Reasons for taking a Wife" is the stability offered a man through marital union. The wife constitutes an anchor by which he can steady his world and "Secure at once himself and heaven to please." The wife is variously referred to in the piece as [emphasis mine] the "constant spouse," that "One solid comfort," and "our eternal wife" as well as a divine blessing that "lasts... As long as e're a heart can with - and longer too," language that explicitly links her with solidity and security. Though circumstances might threaten disaster, marriage would endure and calm troubled waters, for "Tho' fortune change, his constant spouse remains, Augments his joys, or mitigates his pains." In passages that speak to the political and economic instability of Newport and the anxiety of its inhabitants on the eve of revolution, the composition assures its reader that though "Vain fortune's favours, never at a stay, Like empty shadows glide and pass away; One solid comfort, our eternal wife, Abundantly supplies us all our life." "Can he That has a wife," the piece asks, "e'er feel adversity?" Absolutely not. An appealing message in a city wracked by conflict, the reason for taking a wife is thus made distinctly clear - to construct a foundation upon which to weather misfortune and overcome adversity. Less than two months before anxieties over the community's fate exploded with the sinking of the Liberty in Newport harbor, readers of the Newport Mercury were presented with another vision of the sheer bliss borne by matrimony in an idyllic composition entitled "The Contented Pair." The piece weaves together issues of political, economic, and social import to create a model of republican life likely very attractive to residents of the battered seaport. 
In contrast to the cramped, crowded conditions of the bustling city, "The Contented Pair" is set in the serenity of a country estate in which beauty and fertility prevail. The couple's garden is always "full of fruits and flowers," their "orchard richly stor'd with fruit," "Daisies o'er spread th' enamel'd ground," and in general they find "The fertile Lands and fruitful fields, Enlivening all that nature yields." 90 Such productivity, of course, contrasted greatly with the predicament of Newport at the time, where fishing boats were frequently inactive "from fear of an Impress on Board his Majesty's ship[s]," firewood was perpetually in short supply, and a number of the city's many women were "oblig'd to borrow and some beg." 91 Surrounded by plenty and "Blest with two lovely girls and boys," the sanguine couple "cheerful pass the time away." The fruits of their marriage have brought the two contentment, for "Tho' some would call our cottage mean... We neither ask nor wish for more." The message being conveyed here is distinctly republican.

Historians have noted the employment of works such as those of Thomas Gordon and John Trenchard that used classical thought to attack extravagance and greed as the bane of freedom. Gordon Wood insists that "Invoking these classical ideals became the major means by which dissatisfied Britons on both sides of the Atlantic voiced their objections to the luxury, selfishness, and corruption of the monarchical world they lived in."92 The fictitious couple of the Mercury piece expressed their contempt of such extravagance as did actual Newporters. While one wearied resident wondered "Whether a Lady set out with foreign Silks and Laces, may not be

\footnotetext{
90 Newport Mercury, May 29, 1769.

91 Newport Mercury, May 7, 1764; Newport Mercury, June 5, 1769.

92 Wood, Gordon S., The Radicalism of the American Revolution, (New York, N.Y.: Vintage Books, 1991), 101.
} 
said to consume more Beef and Butter than a hundred Farmers?,"93 the composition's characters decried "pride, with all her haughty train: Or blaze and splendour of a Court, where Honour's often but a Sport." Given the aggrieved circumstances of their once prosperous and harmonious seaport, it is likely that Newporters were also to understand from the piece that living with less could in fact be a gratifying experience, as readers were instructed that "To wish for more were but a jest, To Providence we leave the rest." The foundation of such contentment, however, rests with the institution of marriage. The whole composition is built around the couple's union and without it the scenario quickly collapses. As both a veiled attack on aristocratic corruption and a discourse on local conditions, "The Contented Pair" illustrates the fusion of anxieties over gender with those over the great political and economic issues of the day in Newport. As if to underline this connection, the publishers of the Newport Mercury chose to publish directly below "The Contented Pair" a discourse entitled "Shall I go to war with my American brethren?"

${ }^{93}$ Newport Mercury, August 27, 1764. 
The emergence of a commercialized economy in eighteenth century Newport and the implications of that development for its inhabitants profoundly shaped the city's conception of itself and provided the framework for a discourse that could at once embrace radical change yet extol the virtue of women's "primitive and most ancient" conditions. A city so dependent on commercial shipping indeed left its economy dependent on the caprices of others, an uncomfortable position in an era that was quickly coming to condemn dependency as the bane of true freedom. The fragility of Newport's economy in the eighteenth century was made readily apparent when the British government determined to enforce its perceived dominion over the colonial economy. Significantly, however, Newporters encountered during the Revolutionary era threats to individual and community prosperity at the very time both the populace and the local economy experienced a conspicuous feminization, a condition shared by other colonial cities as well.

Historians such as Kenneth Lockridge have noted the impact of such a development on men in the eighteenth century. "[N]ot only marginal and anomalous elites, but also established ones faced with the feminization of marginal and central areas of public life, were prone to misogyny, and to a nervous masculinization of power."1 Steeped in a culture that emphasized material gain, community leaders attempted various schemes to preserve prosperity and status in Newport amid the growing chaos of the Revolutionary era. Arising from the friction within the city and fashioned by republican ideology was a discourse that linked economic fortune and

${ }^{1}$ Lockridge, Kenneth A., On the Sources of Patriarchal Rage: The Commonplace Books of William Byrd and Thomas Jefferson and the Gendering of Power in the Eighteenth Century, (New York, N.Y.: New York University Press, 1992), 108. 
personal happiness to a particular mode of gender relations, matrimony, and hence implied that the loss of either of the former was somehow attributable to the decline of the latter. Such a formula accorded woman a crucial role in maintaining comfort and stability within the seaport, but only a certain type of woman - a married woman. It was this pattern of pre-Revolutionary thought that would yield such post-Revolutionary concepts as the Republican Wife and/or the Republican Mother. As such, the linkage between economic fortune and the wife/mother evident in the Newport discourse adds an economic dimension to these concepts that has remained relatively unexplored by historians, who have instead focused on the political significance of the Republican Wife and the Republican Mother. And it is important to bear in mind that the political rhetoric of the Revolution was always intimately tied to economic concerns, thus necessarily making such political concepts as the Republican Wife and Mother economic concepts as well.

Joan Hoff has noted that "[p]rivatization and patriotic feminization of virtue came at the very moment when postrevolutionary leaders were getting on with the business of carving out political privileges and economic opportunities for themselves and for many succeeding generations of white males."2 In cities like Newport, however, the paramount significance given women in the conception of virtue through matrimony and child-bearing emerged also at the very time women were increasingly carving out independent existences for themselves through the commercialization of feminine occupations. "Republican motherhood," Jeanne Boydston has discovered, "emphasized women's child-rearing responsibilities almost to the

2 Hoff, Joan Hoff, Law, Gender, and Injustice: A Legal History of U.S. Women, (New York, N.Y.: New York University Press, 1991), 38. 
exclusion of the remainer of their work - a vision of domestic labor which was sharply at odds with the reality of their lives." 3 It seems likely, then, that the curious disjuncture between ideology and reality of women's lives was more than a mere oversight. In a place like Newport, it represented a bid to render women economically inert by convincing them of the importance of returning to the alter and the home. "More telling, if more diffuse," writes Boydston, "was that the ideology of civic republicanism revived a rationale for denying women's significance as economic agents."4

Prior to the outbreak of war, the ardent patriot Ezra Stiles of Newport expressed his hope that one day "Free polity, free religion, free prosperity, and matrimony [would] soon populate a fertile country in a good climate."5 $\mathrm{A}$ revealing comment, Stiles's remark captures in many ways the interconnectedness of politics, religion (Stiles was then a Congregational minister), the economic order, and gender in the mind of one Newporter. Far from being understood as a distinctly private institution that possessed little relevance for the health of the public realm, matrimony was given equal billing by Stiles in his vision for the colonies. Like so many of his contemporaries, matrimony had a significance for him beyond an expression of love and God's will; it was constructed as a central pillar of societal progress. Progress, however, was not to be the lot of Newporters.

As the waves of revolution continued their relentless assault on the shores of Newport, the anxiety over imminent war proved too much for many city residents to handle. After the British warship Rose fired on the city and made clear its orders to "lay the town in Ashes," few maintained any

\footnotetext{
3 Boydston, Jeanne, Home and Work, (New York, N.Y.: Oxford University Press, 1990), 43. 4 Ibid., 43.

5 as quoted in Skemp, Sheila L., A Social and Cultural History of Newport, Rhode Island, 1720 - 1765, (Ph.D. dissertation: The University of Iowa, 1974), 428.
} 
pretensions that war could still be avoided. As the chronicle of all goings-on in the once-proud community, the Newport Mercury reported in October of 1775 that so many inhabitants were quitting Newport that "[t]he carts, chaises, riding chairs and trucks, were so numerous that the streets and roads were almost blocked up with them."6 Many who left would never return. The atmosphere of wartime Newport could hardly have been conducive to the maintenance of cohesive personal relationships, either for those who left or for those who stayed, despite the rhetoric to the contrary. Months later, a more somber Ezra Stiles noted of his city that "more than three quarters of the Inhabitants are removed..." and after the British military took complete control of the city in December of 1777 that "the town is in Ruins."7 Newport, Rhode Island, would never regain its former greatness.

If interactions within the late colonial American cities presaged the evolution of life for nineteenth century Americans, as some historians suggest, then we must look long and hard at the tenor of thought and action in colonial urbanity to properly assess continuity in American history as well as change. Many of the trends Newport experienced just prior to the American Revolution - intense commercialization, greater transiency and disparity in wealth, sexual imbalance, more and more widowed and single women, and increased female presence in wage-earning capacities among others - were experienced by other colonial cities as well. And though Newport as a functioning city was largely destroyed by the War for Independence, these trends were carried into the nineteenth century by those cities like Boston and Philadelphia that did survive the war. For instance,

${ }^{6}$ Newport Mercury, October 9, 1775.

7 as quoted in Crane, A Dependent People, 123 and 144. 
Lee Virginia Chambers-Schiller contends that "[t]he expansion of the single population from 1790 to 1865 ,...was rooted in the transformations of American society from a production-based domestic economy to a consumerbased household economy," a process most advanced in the cities on the eve of independence. ${ }^{8}$ In his investigation of early American inheritance patterns, Daniel Scott Smith discovered that before and after independence, young widows residing in urban areas, like those we have examined in Newport, consistently managed gainful employment. "An astonishing 80 percent of the female household heads (a group overwhelmingly composed of widows) enumerated in the 1810 census in the central sections of Philadelphia were listed with occupations."

Even among those historians who hail the American Revolution as a positive step forward for American women, the conservative nature of republican rhetoric as it pertained to gender is generally acknowledged. The conservatism of such discourse as that found in Newport in the 1760s and 1770 s is frequently recognized as the foundation of the nineteenth century "Cult of Domesticity." "The legacy of the American Revolution for women," Mary Beth Norton concedes "was thus amibiguous [as] Republican womanhood eventually became Victorian womanhood..."10 Joan Hoff more forcefully insists that "the terms republican wife and republican mother obfuscate how male ideology and the law upon which it functioned confined women to their private sphere."11 Revolutionary discourse such as that found

\footnotetext{
${ }^{8}$ Chambers-Schiller, Lee Virginia, Liberty, A Better Husband, (New Haven, Conn.: Yale University Press, 1984), 45.

9 Smith, Daniel Scott, "Inheritance and the Social History of Early American Women," Women in the Age of the American Revolution, eds. Ronald Hoffman and Peter J. Albert (Charlottesville, Virginia: University Press of Virginia, 1989), 60.

10 Norton, Mary Beth, Liberty's Daughters, (Boston, Mass.: Little, Brown, and Company, 1980), 299.

${ }^{11}$ Hoff, Law, Gender, \& Injustice, 38.
} 
in the Newport Mercury "left [women] with an odd contextual combination of aspects of the classical concept of public virtue that men were abandoning and a type of 'maternal value' that presaged... the development of the 'cult of true womanhood'..."12 Riding the tide of revolution, the connections between women, work,war, and wedlock that flowed through seaport cities like Newport in late eighteenth century America indeed rippled into the new century to influence an infant nation.

12 Ibid., 39. 
Bibliography

\section{Primary Sources}

Acts and Laws of The English Colony of Rhode Island and Providence Plantations, in New England, in America, printed by Samuel Hall, (Newport, R.I., 1767).

Colonial Records of Rhode Island, ed. by John Russell Bartlett (Providence, R.I.: Knowles, Anthony \& Company, 1861), Volume 4 (1707-1740) through Volume 9 (1780-1783).

Court of General Sessions of the Peace Record Book, Volume I (1746-1837), Rhode Island Judicial Archives: Pawtucket, Rhode Island.

George H. Richardson Scrapbook, Newport Historical Society: Newport, Rhode Island.

Newport Town Council Record Book, Volume 11 (1750-1755), Newport Historical Society: Newport, Rhode Island.

Newport Town Council Record Book, Volume 13, (1760-1763), Newport Historical Society: Newport, Rhode Island.

Newport Mercury, 1758-1775.

Rhode Island Inferior Court of Common Pleas Record Books, Volumes C (1746-1751) through I (1771-1775), Rhode Island Judicial Archives: Pawtucket, Rhode Island.

Rhode Island Sureme Court Record Books, Volumes D (1747-1750) through Volume F (1772-1795), Rhode Island Judicial Archives: Pawtucket, Rhode Island.

- Stiles, Ezra, The Literary Diary of Ezra Stiles, ed. Franklin B. Dexter, 3

Volumes, (New York, N.Y., 1901), Newport Historical Society.

Tax Assessment for the town of Newport, 1772, Newport Historical Society: Newport, Rhode Island.

Tax Assessment for the town of Newport, 1775, Newport Historical Society.

Secondary Sources

Bain, June, "A Tale of Two Husbands," Yankee (September 1960): 64, 69, 106. 
Baller, Bill, "Kinship and Culture in the Mobilization of Colonial Massachusetts," The Historian, Vol. 57, (Winter 1995): 291-302.

Blewett, Mary H., "The Sexual Division of Labor and the Artisan Tradition in Early Industrial Capiatlism: The Case of New England Shoemaking, 1780-1860," To Toil the Livelong Day, eds. Carol Groneman and Mary Beth Norton, (Ithaca, N.Y.: Cornell University Press, 1987): 35-46.

Boydston, Jeanne, Home and Work: Housework, Wages, and the Ideology of Labor in the Early Republic, (New York, N.Y.: Oxford University Press, 1990).

- Breen, T.H., "An Empire of Goods: The Anglicanization of Colonial America, 1690-1776," Colonial America, fourth edition, ed. by Stanley Katz, John Murrin, and Douglas Greenberg, (New Yirk, N.Y.: Mcgraw-Hill, Inc., 1993): 367-398.

Bridenbaugh, Carl, Fat Mutton and Liberty of Conscience: Society in Rhode Island, 1636-1690, (Providence, R.I.: Brown University Press, 1974).

Bridenbaugh, Carl, Cities in the Wilderness: The First Century of Urban Life in America, 1625-1742, (New York, N.Y.: Alfred A. Knopf, 1960).

Buel, Joy Day, and Buel, Richard, Jr., The Way of Duty: A Woman and Her Family in Revolutionary America, (New York, N.Y.: W.W. Norton and Company, reissue 1995).

Bushman, Richard L., From Puritan to Yankee: Character and the Social Order in Connecticut, 1690-1765, (Cambridge, Mass: Harvard University Press, 1967).

Chambers-Schiller, Lee Virginia, Liberty, A Better Husband, (New Haven, Conn.: Yale University Press, 1984).

Clark, Bertha W., Genealogy of Carrs, (Newport Historical Society, 1954).

Clark, Charles E., and Wetherell, Charles, "The Measure of Maturity: The Pennsylvania Gazette, 1728-1765," The William and Mary Quarterly Vol. XLVI, No. 1 (April 1989): 279-303.

Cleary, Patricia "'She Will Be in the Shop': Women's Sphere of Trade in Eighteenth-Century Philadelphia and New York," The Pennsylvania Magazine of History and Biography Vol. CXIX, No.3 (July 1995): 181202.

Cohen, Joel A., "Rhode Island Loyalism and the American Revolution," Rhode Island History, Vol. 27, No. 4 (October 1968): 97-112. 
Cohen, Joel A., "Molasses to Muskets - Rhode Island 1763-1775," Rhode Island History Vol. 34:4 (November 1975): 99-103.

Cohn Carol, "War, Wimps, and Women: Talking Gender and Thinking War," Gendering War Talk, eds. Miriam Cooke and Angela Woollacott, (Princeton, N.J.: Princeton University Press, 1993): 227-246.

Coleman, Peter J., "The Insolvent Debtor in Rhode Island," The William and Mary Quarterly 3rd Series, Vol. XXII (July 1965): 413-434.

Crane, Elaine Forman, A Dependent People: Newport, Rhode Island in the Revolutionary Era, (New York, N.Y.: Fordham University Press, 1985).

Daniels, Bruce C., Dissent and Conformity on Narragansett Bay: The Colonial Rhode Island Town, (Middletown, Conn.: Wesleyan University Press, 1983).

Daniels, Bruce C., Puritans at Play, (New York, N.Y.: St. Martin's Press, 1995).

Dayton, Cornelia Hughes, Women Before the Bar: Gender, Law, \& Society in Connecticut, 1639-1789, (Chapel Hill, N.C.: The University of North Carolina Press, 1995).

Demos, John, A Little Commonwealth: Family Life in Plymouth Colony, (New York, N.Y.: Oxford University Press, 1970).

Demos, John, "Families in Colonial Bristol, Rhode Island: An Exercise in Historical Demography," The William and Mary Quarterly, 25 (January 1968): 40-57.

Deutsch, Sarah, No Separate Refuge: Culture, Class, and Gender on an Anglo-Hispanic Frontier in the American Southwest, 1880-1940, (New York, N.Y.: Oxford University Press, 1987).

Fliegelman, Jay, Prodigals and Pilgrims: The American Revolution Against Patriarchal Authority, 1750-1800, (Cambridge, England: Cambridge University Press, 1982).

Franklin, Benjamin, Autobiography, (New York, N.Y.: Bantam Books reprint, 1982).

Good, Douglas L., "Colonials at Play: Leisure in Newport 1723," Rhode Island History, Vol. 33, No. 1 (February 1974): 9-17.

Greene, Lorenzo Johnston, The Negro in Colonial New England, 1620-1776, (Port Washington, N.Y.: Kennikat Press, Inc., 1966). 
Grigg, Susan, "Toward a Theory of Remarriage: A Case Study of

Newburyport at the Beginning of the Nineteenth Century," Journal of

Interdisciplinary History, Vol. VIII:2 (Autumn 1977): 183-220.

Hambrick-Stowe, Charles E., "The Spiritual Pilgrimage of Sarah Osborn (1714-1796)," Church History, Vol. 61, No. 4 (December 1992): 408421.

Hawke, David Freeman, Everyday Life in Early America, (New York, N.Y.: Harper and Row, Publishers, 1989).

Hawthorne, Nathaniel, The House of the Seven Gables, (New York, N.Y.: Bantam Classics reprint, 1981).

Hemphill, C. Dallett, "Women in Court: Sex-Role Differentiation in Salem, Massachusetts, 1636-1683," William and Mary Quarterly 3rd Series, Vol. XXXIX (January 1982): 164-175.

Hoff, Joan, Law, Gender, and Injustice, (New York, N.Y.: New York University Press, 1991).

Innes, Stephen, Creating the Commonwealth, (New York, N.Y.: W.W. Norton and Company , 1995).

James, Sydney V., Colonial Rhode Island - A History, (New York, N.Y.: Charles Scribner's Sons, 1975).

Jensen, Joan M., Loosening the Bonds: Mid-Atlantic Farm Women, 17501850, (New Haven, Conn.: Yale University Press, 1986).

Karlsen, Carol F., The Devil in the Shape of a Woman, (New York, N.Y.: Vintage Books, 1987).

Kerber, Linda, Women of the Republic, (Chapel Hill, N.C.: University of North Carolina Press, 1980).

Koehler, Lyle, A Search for Power: The "Weaker Sex" in Seventeenth-Century New England, (Urbana, Ill.: University of Illinois Press, 1980).

Lebsock, Suzanne, The Free Women of Petersburg: Status and Culture in a Southern Town, 1784-1860, (New York, N.Y.: W.W. Norton and Company, 1984).

Leighton, Ann, American Gardens in the Eighteenth Century, (Boston, Mass.: Houghton Mifflin Company, 1976).

Lemisch, Jesse, "Jack Tar in the Streets: Merchant Seamen in the Politics of Revolutionary America," The William and Mary Quarterly, 3rd Series, Vol. XXV (July 1968): 371-407. 
Lewis, Jan, "The Republican Wife: Virtue and Seduction in the Early Republic," American Vistas: 1607-1877, ed. by Leonard Dinnerstein and Kenneth T. Jackson (New York, N.Y.: Oxford University Press, 1995): $160-189$.

Lockridge, Kenneth A., On the Sources of Patriarchal Rage: The Commonplace Books of William Byrd and Thomas Jefferson and the Gendering of Power in the Eighteenth Century, (New York, N.Y.: New York University Press, 1992).

Main Gloria L., "Gender, Work, and Wages in Colonial America," The William and Mary Quarterly, 3rd Series, Vol. LI (January 1994): 39-66.

Main, Gloria L., "Widows in Rural Massachusetts on the Eve of the Revolution," Women in the Age of the American Revolution, eds. Ronald Hoffman and Peter J. Albert (Charlottesville, Virginia: University of Virginia Press, 1989): 67-90.

Manuel, Elton, Grant Families of Newport, (Newport Historical Society, 1990).

Matthaei, Julie A., An Economic History of Women in America: Women's Work, the Sexual Division of Labor, and the Development of Capitalism, (New York, N.Y.: Schocken Books, 1982).

Morgan, Edmund S., The Puritan Family, (New York, N.Y.: Harper and Row, 1966).

- Nash, Gary, The Urban Crucible: The Northern Seaports and the Origins of the American Revolution, (Cambridge, Mass.: Harvard University Press, 1986).

Norling, Lisa, "'How Frought with Sorrow and Heartpangs': Mariners' Wives and the Ideology of Domesticity in New England, 1790-1880," The New England Quarterly 65 (September 1992): 422-446.

Norton, Mary Beth, Founding Mothers and Fathers: Gendered Power and the Forming of American Society, (New York, N.Y.: Alfred A. Knopf, 1996).

Norton, Mary Beth, "'My Resting Reaping Times': Sarah Osborn's Defense of Her 'Unfeminine' Activities, 1767," Signs, Vol. 2 (1976): 515-529.

Norton, Mary Beth, Liberty's Daughters, (Boston, Mass.: Little, Brown, and Company, 1980).

The Papers of Benjamin Franklin, Volume 2: January 1, 1735 through December 31, 1744, ed. by Leonard W. Labaree (New Haven, Conn.: Yale University Press, 1960). 
Parker, Joseph Peter, "Slavery in Rhode Island," (Master of Arts thesis: University of Rhode Island, 1962).

Piersen, William, Black Yankees, (Amherst, Mass.: The University of Massachusetts Press, 1988).

Platt, Virginia Bever, "'And Don't Forget the Guinea Voyage': The Slave Trade of Aaron Lopez of Newport," The William and Mary Quarterly, 3rd Series, Vol. XXXII, (October 1975): 601-618.

Price, Jacob M., "Economic Function and the Growth of American Port Towns in the Eighteenth Century," Perspectives in American History, Vol. 8 (1974): 123-186.

Ricketson, William F., "To Be Young, Poor, and Alone: The Experience of Widowhood in the Massachusetts Bay Colony, 1675-1676," The New England Quarterly 64 (March 1991): 113-127.

Riley, Glenda, Divorce: An American Tradition, (New York, N.Y.: Oxford University Press, 1991).

Salmon, Marylynn, Women and the Law of Property in Early America, (Chapel Hill, N.C.: The University of North Carolina Press, 1986).

Scott, Joan Wallach, Gender and the Politics of History, (New York, N.Y.: Columbia University Press, 1988).

Shammas, Carole, "Early American Women and Control over Capital," Women in the Age of the American Revolution, eds. Ronald Hoffman and Peter J. Albert (Charlottesville, Va.: University Press of Virginia, 1989): 134-154.

Shammas, Carole, "The Female Social Structure of Philadelphia in 1775," The Pennsylvania Magazine of History and Biography 107 (January 1983): 69-83.

- Skemp, Sheila, A Social and Cultural History of Newport, Rhode Island: 1720-1765, (Ph.D. dissertation: The University of Iowa, 1974).

Smith, Daniel Scott, "Inheritance and the Social History of Early American Women," Women in the Age of the American Revolution, eds. Ronald Hoffman and Peter J. Albert (Charlottesville, Virginia: University Press of Virginia, 1989): 45-66.

Stansell, Christine, City of Women: Sex and Class in New York, 1789-1860, (Urbana, Ill.: Illinois University Press, 1987). 
Stavisky, Leonard, "The Origins of Negro Craftsmanship in Colonial America," The Other Slaves: mechanics, artisans, and craftsmen, ed. by James E. Newton and Ronald L. Lewis (Boston, Mass.: G.K. Hall \& Co., 1978): 183-191.

Ulrich, Laurel Thatcher, Good Wives: Images and Reality in the Lives of Women in Northern New England, 1650-1750, (New York, N.Y.: Oxford University Press, 1982).

Ulrich, Laurel Thatcher, "Housewife and Gadder: Themes of Self-Sufficiency and Community in Eighteenth Century New England," "To Toil the Livelong Day": America's Women at Work, 1780-1980, eds. Carol Groneman and Mary Beth Norton (Ithaca, N.Y.: Cornell University Press, 1987): 21-34.

Ulrich, Laurel Thatcher, "'Daughters of Liberty': Religious Women in Revolutionary New England," Women in the Age of the American Revolution, eds. Ronald Hoffman and Peter J. Albert (Charlottesville, Virginia: University Press of Virginia, 1989): 211-243.

Ulrich, Laurel Thatcher, A Midwife's Tale: The Life of Martha Ballard, Based on Her Diary, 1785-1812, (New York, N.Y.: Vintage Books, 1990).

Wall, Helena M., Fierce Communion: Family and Community in Early America, (Cambridge, Mass.: Harvard University Press, 1990).

Warner, Michael, The Letters of the Republic: Publication and the Public Sphere in Eighteenth-Century America, (Cambridge, Mass.: Harvard University Press, 1990).

Wilson, Lisa, Life After Death: Widows in Pennsylvania, 1750-1850, (Philadelphia, Pa.: Temple University Press, 1992).

Withey, Lynne, "Household Structure in Urban and Rural Areas: The Case of Rhode Island, 1774-1800," Journal of Family History, Vol. 3 (1978): 37-50.

Withey, Lynne, Urban Growth in Colonial Rhode Island, (Albany, N.Y.: State University of New York Press, 1984).

Wood, Gordon S., The Radicalism of the American Revolution, (New York,N.Y.: Vintage Books, 1991). 